\title{
Significance of Complement System in Ischemic Stroke: A Comprehensive Review
}

\author{
Yuanyuan Ma',2\#, Yanqun Liu ${ }^{3}$, Zhijun Zhang' ${ }^{2}$ Guo-Yuan Yang ${ }^{1,2}$ * \\ ${ }^{1}$ Department of Neurology, Ruijin Hospital, School of Medicine, Shanghai Jiao Tong University, Shanghai, \\ China \\ ${ }^{2}$ Med-X Research Institute and School of Biomedical Engineering, Shanghai Jiao Tong University, Shanghai, \\ China \\ ${ }^{3}$ Department of Neurology, Changhai Hospital, Second Military Medical University, Shanghai, China \\ ${ }^{\sharp}$ Currently address: Department of Neurology, Zhongshan Hospital, Fudan University, Shanghai, China
}

[Received October 23, 2018; Revised January 16, 2019; Accepted January 19, 2019]

\begin{abstract}
The complement system is an essential part of innate immunity, typically conferring protection via eliminating pathogens and accumulating debris. However, the defensive function of the complement system can exacerbate immune, inflammatory, and degenerative responses in various pathological conditions. Cumulative evidence indicates that the complement system plays a critical role in the pathogenesis of ischemic brain injury, as the depletion of certain complement components or the inhibition of complement activation could reduce ischemic brain injury. Although multiple candidates modulating or inhibiting complement activation show massive potential for the treatment of ischemic stroke, the clinical availability of complement inhibitors remains limited. The complement system is also involved in neural plasticity and neurogenesis during cerebral ischemia. Thus, unexpected side effects could be induced if the systemic complement system is inhibited. In this review, we highlighted the recent concepts and discoveries of the roles of different kinds of complement components, such as C3a, C5a, and their receptors, in both normal brain physiology and the pathophysiology of brain ischemia. In addition, we comprehensively reviewed the current development of complement-targeted therapy for ischemic stroke and discussed the challenges of bringing these therapies into the clinic. The design of future experiments was also discussed to better characterize the role of complement in both tissue injury and recovery after cerebral ischemia. More studies are needed to elucidate the molecular and cellular mechanisms of how complement components exert their functions in different stages of ischemic stroke to optimize the intervention of targeting the complement system.
\end{abstract}

Key words: brain, C3a, C5a, complement, ischemic stroke

\section{Introduction}

Stroke is the most common cerebral vascular disease and a leading cause of permanent disability and death worldwide today $[1,2]$. The traditional definition of stroke is based on the sudden onset of the loss of focal neurological function due to infarction or hemorrhage in the relevant portion of the brain [3]. There are two main types of stroke: ischemic stroke and hemorrhagic stroke.
The majority of strokes are ischemic (70-80\%) and have various mechanisms and management approaches compared to hemorrhagic strokes [4]. Over the past several decades, there has been substantial progress in the understanding of the pathophysiology of ischemic stroke. Following an ischemic stroke attack, patients could show blood flow restoration in the infarct region, either endogenous thrombolytic system activation or exogenous thrombolytic therapy. Cerebral blood flow reperfusion

*Correspondence should be addressed to: Drs. Zhijun Zhang and Guo-Yuan Yang, Med-X Research Institute, Shanghai Jiao Tong University, Shanghai, China. Email: gyyang0626@163.com and zhangdragon2012@163.com

Copyright: () 2019 a Y et al. This is an open-access article distributed under the terms of the Creative Commons Attribution License, which permits unrestricted use, distribution, and reproduction in any medium, provided the original author and source are credited. 
initiates a cascade of pathophysiological events that could aggravate brain tissue damage, leading to more severe neurological function and cognitive deficits [5]. Currently, the molecular mechanism of cerebral ischemia/reperfusion injury is not completely elucidated; however, complement activation and its products have been found to be strongly implicated in one of the putative mechanisms [6]. A large set of data showed that complement inhibition could improve the outcomes of ischemic stroke in many animal models [7]. The involvement of the complement system in the pathogenesis of human ischemic stroke has been demonstrated by findings of local deposits of various complement components in the post-stroke brain tissue [8, 9]. Numerous approaches targeting complement were tried to reduce ischemic damage, including inhibition of complement component 1 (C1), complement component 3 (C3), complement component 5 (C5), and membrane attack complex (MAC, C5b-9). Cobra venom factor (CVF) and intravenous immunoglobulin (IVIg) were also used to deplete the complement or inhibit complement activation in experimental studies. Although the results were optimistic, few commercial products reached the market [10-12]. In addition, emerging evidence showed that complement was essential for tissue repair and regeneration [13]. Nevertheless, the role of complement components in cerebral ischemia is still poorly understood [14]. In this review, we will highlight recent discoveries about the roles of complement components in the pathophysiology of ischemic stroke and review the therapeutic strategies targeting complement both in clinical and experimental studies for ischemic stroke therapy. We aim to provide valuable information for exploring the role of the complement system and designing therapeutic strategies for ischemic stroke therapy in the future.

\section{Complement in ischemic stroke}

The complement system is essential for the innate immune response and plays a vital role in host defense and tissue homeostasis $[15,16]$. The complement system is composed of more than 50 different plasma and membrane-associated proteins, and it can be activated through three different pathways: the classical, lectin, and alternative pathways [17]. Traditionally, it was considered that the complement system was primarily tagging and eliminating microbial intruders after activation. However, except for microbe elimination, the functions of the complement system have been highly extended over the past decades. To date, the complement system has been recognized as a participant in diverse processes, including clearance of immune complexes, mobilization of hematopoietic stem/progenitor cells (HSPC), angiogenesis, synapse pruning and maturation, tissue regeneration, and lipid metabolism [18]. Growing evidence has shown that the activity of the complement system is complicated and is involved in multiple immune, inflammatory, neurodegenerative, age-related, and ischemic diseases. In recent years, clinical observations and experimental studies have indicated that the complement system is crucial in the propagation of ischemic stroke [6, 19]. After cerebral ischemia, complement components synthesized by local activated cerebral endothelial cells, neurons, and glial cells, as well as complement derived from leukocytes, were strongly implicated in the progression of the disease [10].

\subsection{C1q}

$\mathrm{C} 1 \mathrm{q}$ is well known to form the $\mathrm{C} 1$ macromolecule complex and initiates the classical complement pathway [20]. C1q contributes to the removal of infectious agents, apoptotic cells, and immune complexes [21]. Normally, $\mathrm{C} 1 \mathrm{q}$ is present with proenzymes $\mathrm{C} 1 \mathrm{r}$ and $\mathrm{C} 1 \mathrm{~s}$ in blood. However, C1q could also be synthesized in the brain after injury, such as viral infection, kainic acid treatment, and ischemic stroke [22-24]. In the developing visual system, $\mathrm{C} 1 \mathrm{q}$ is expressed in synaptic regions of neurons and regulated by TGF- $\beta$. Depletion of C1q in knock-out mice resulted in impaired elimination of redundant synapses and excessive synaptic connectivity, which could lead to epileptogenesis and epilepsy [25-27]. In a normal brain, $\mathrm{Clq}$ is present in the neuropil, microglia, and a subset of interneurons [28]. After ischemic stroke, ischemic neurons predominantly expressed $\mathrm{C} 1 \mathrm{q}$, which may favor the attack or clearance of damaged neurons or cellular debris $[24,29]$. In a model of transient middle cerebral artery occlusion (MCAO) in mice, salidroside treatment reduced $\mathrm{C} 1 \mathrm{q}$ expression in the brain after 48 hours of brain ischemia, which was associated with enhanced NeuN and the expression of the growth response proteins Egr1, Egr2 and Egr4 [30]. In a model of hypoxia-ischemia in neonatal mice, selective depletion of Clq via the gene knock-out method reduced neutrophil infiltration, oxidative injury, and brain infarct volume after 24 and 72 hours of cerebral ischemia [31, 32]. These studies indicated that inhibiting $\mathrm{Clq}$ expression during the acute phase of cerebral ischemia could be beneficial to attenuate ischemic brain injury. However, another study showed that $\mathrm{C} 1 \mathrm{q}$ knockout in adult mice subjected to MCAO surgery did not affect brain infarct volume at 24 hours after ischemia [33, 34]. Although the models of cerebral ischemia are different among the studies mentioned above, the pathological process of cerebral ischemia is common. Therefore, the authors speculated that the discordant results may result from the distinct maturation of the complement system between neonatal and adult 
mice [31]. Thus, the function of $\mathrm{C} 1 \mathrm{q}$ and the effect of its upregulation on brain injury or tissue repair at different time points of cerebral ischemia need to be further investigated, especially in the late phase of the disease. These findings will help improve the design of proper therapeutic interventions targeting $\mathrm{Clq}$ against ischemic brain injury.

\subsection{C3}

\subsubsection{Introduction of $\mathrm{C3}$}

$\mathrm{C} 3$ is the most abundant complement protein in blood and is a central protein of all complement pathways [35]. Therefore, as one of the most extensively studied complement components, its structure and physiological function have been thoroughly studied [36-40]. C3 is activated and cleaved by $\mathrm{C} 3$ convertase into $\mathrm{C} 3 \mathrm{a}$ and $\mathrm{C} 3 \mathrm{~b}$. C3a could attract immune cells, modulate the immune response, and mediate downstream inflammatory responses by interacting with the cellular receptor complement component $3 \mathrm{a}$ receptor $(\mathrm{C} 3 \mathrm{aR})$. $\mathrm{C} 3 \mathrm{~b}$ and its degradation products $\mathrm{iC} 3 \mathrm{~b}$ and $\mathrm{C} 3 \mathrm{dg}$ interact with cellular receptors, including complement receptor 1 (CR1, CD35), complement receptor 2 (CR2, CD21), complement receptor 3 (CR3, CD11b/CD18), complement receptor 4 (CR4, CD11c/CD18), and 'V-set immunoglobulin-domain-containing 4' (VSIg4, CRIg) on effector cells, mediating the clearance of pathogens and dying cells and modulating the adaptive immune response [41-45].

\subsubsection{C3 and ischemic stroke}

\section{Clinical studies of $C 3$ in ischemic stroke}

Clinical studies found that the level of $\mathrm{C} 3$ in plasma was higher in ischemic stroke patients than that in the healthy controls, and it peaked 3 days after brain ischemia [4648]. Elevated $\mathrm{C} 3$ in plasma from embolic ischemic stroke or cryptogenic stroke patients was associated with worse neurological outcomes 3 months and 2 years after ischemia onset $[49,50]$. Similarly, a recent study focusing on young ischemic stroke patients (18-50 years) also showed that the level of $\mathrm{C} 3$ in plasma was related to the prognosis 3 months after ischemic stroke [51]. In addition, genetic variation in the $\mathrm{C} 3$ gene was found to be associated with ischemic stroke, particularly with cryptogenic stroke [52]. These findings suggested that the systemic level of $\mathrm{C} 3$ could be a potential predictor of outcome after ischemic stroke.

Experimental studies of $\mathrm{C} 3$ in ischemic stroke
In the CNS, $\mathrm{C} 3$ has a role in nonimmune neuronal function [53-55] and is produced by several cell types, including neurons, astrocytes, microglia and oligodendrocytes [56-60]. It was reported that $\mathrm{C} 3$ was activated in ischemic tissue and implicated in ischemiareperfusion injury $[5,61,62]$. C3 was increased in the brain after ischemic stroke, and inhibiting $\mathrm{C} 3$ activity could attenuate ischemic brain injury. In neonatal and adult rats subjected to hypoxia-ischemia surgery, the administration of CVF inhibited ischemia-induced $\mathrm{C} 3$ upregulation and reduced the brain infarct volume after 2 to 5 days of brain ischemia [63,64]. In a mouse model of transient $\mathrm{MCAO}$, inhibiting $\mathrm{C} 3$ activity via genetic knockout or antioxidant N-tert-butyl- $\alpha$-phenylnitrone treatment could alleviate inflammatory response, reduce brain infarct volume, and attenuate neurological deficiency following 1 to 7 days of brain ischemia. In vitro studies showed that inhibiting C3 expression via small interfering RNA transfection enhanced cultured neuron viability under oxygen-glucose deprivation (OGD) conditions $[34,65]$. These studies indicated that inhibiting C3 activity could attenuate ischemic brain injury, at least in the acute phase of cerebral ischemia. However, the role of $\mathrm{C} 3$ in the pathophysiology and tissue regeneration after ischemic stroke needs to be further investigated, especially in the subacute and chronic phases of stroke. In a mouse model of transient ischemic stroke, $\mathrm{C} 3$ deficiency via the genetic knock-out method reduced brain infarct volume and neutrophil influx following 1 day of ischemic stroke but impaired subsequent neurogenesis after 7 to 28 days of brain ischemia [5, 66-68]. These results implied that $\mathrm{C} 3$ was neuroprotective during the recovery process of cerebral ischemia, partially through promoting neurogenesis. Thus, $\mathrm{C} 3$ has a dual role during the pathogenesis of ischemic stroke. Therefore, C3 activity should be modulated rather than indiscriminately eliminated, such as with genetic knock-out or depletion with CVF, to attenuate $\mathrm{C} 3$-mediated injury after cerebral ischemia.

\section{Experimental studies of $\mathrm{C} 3 \mathrm{a}$ in ischemic stroke}

$\mathrm{C} 3 \mathrm{a}$ is a $9-\mathrm{kDa}$ anaphylatoxic peptide derived from $\mathrm{C} 3$ and exerts its functions by binding to a specific receptor, $\mathrm{C} 3 \mathrm{aR}$, on effector cells [69]. C3a is involved in mediating both pro-inflammatory and anti-inflammatory activities after complement activation [70]. The pro-inflammatory activities include recruiting and activating leukocytes, promoting mast cell degranulation and smooth muscle contraction, increasing vascular permeability and vasodilation [71], and stimulating the synthesis of cytokines/chemokines [72, 73]. C3a-mediated inflammation contributed to the pathogenesis of pathological conditions in the CNS, such as experimental 
autoimmune encephalomyelitis [74] and ischemic stroke [34]. However, C3a was found to mediate the antiinflammatory response and exert neuroprotective effects in a model of shock $[75,76]$. In vitro studies showed that C3a treatment could protect neurons against excitotoxicity, stimulate microglia to produce neurotrophic growth factor, and promote the differentiation and migration of neural progenitor cells [77-80]. C3a treatment could also prevent cultured astrocytes from death induced by chemical ischemia or OGD by reducing ERK signaling and caspase- 3 activation [81]. In a mouse model of neonatal hypoxia-ischemia, the intraventricular or intranasal administration of $\mathrm{C} 3 \mathrm{a} 1$ hour after ischemia ameliorated cognitive impairment after 6 weeks of cerebral ischemia. The intranasal administration of C3a did not affect tissue loss or the expression of synaptic plasticity-related proteins of pansynaptic marker synapsin I and growth-associated protein 43 in hippocampus [82, 83]. In an adult mouse model of photothrombotic stroke, the intranasal administration of C3a after 7 days of brain ischemia enhanced pansynaptic marker synapsin I and growth-associated protein 43 expression in the peri-infarct cortex and accelerated the complete recovery of forepaw motor function [84]. Although these studies used different models of cerebral ischemia in mice of different ages, the results suggested that administration of $\mathrm{C} 3 \mathrm{a}$ at a certain time after cerebral ischemia was beneficial for neurological function recovery. Since the intranasal administration of $\mathrm{C} 3 \mathrm{a}$ in neonatal and adult mice after cerebral ischemia resulted in different expression levels of synaptic plasticity-related proteins in the brain, future studies aiming to explore the therapeutic mechanism of $\mathrm{C} 3 \mathrm{a}$ on promoting synaptic plasticity need to consider both age and animal model type. In addition, the optimal delivery route of $\mathrm{C} 3 \mathrm{a}$ administration for ischemic stroke therapy also needs to be further studied.

\section{Experimental studies of $C 3 b$ and $i C 3 b$ in ischemic stroke}

$\mathrm{C} 3 \mathrm{~b}$ is another activated fragment of $\mathrm{C} 3$ and can be further cleaved into the inactive end fragment of $\mathrm{iC} 3 \mathrm{~b}$ after recognizing and binding several complement regulators, including factor $\mathrm{H}(\mathrm{FH})$, decay accelerating factor (DAF, CD55), and membrane cofactor protein (MCP, CD46) [85-89]. The complement regulators regulate the generation of $\mathrm{C} 3 \mathrm{~b}$ and stop $\mathrm{C} 3 \mathrm{~b}$ opsonization by breaking down the $\mathrm{C} 3$ convertases, protecting host cells and tissues from inadvertent complement activation. Dysfunction of these regulatory proteins can be due to familial mutations in the complement genes or the presence of autoantibodies against regulators linked to atypical hemolytic uremic syndrome (aHUS), C3 glomerulopathies (C3G), dense deposit disease (DDD) in kidneys and age-related macular degeneration (AMD) in eyes [90-94]. C3b and $\mathrm{iC} 3 \mathrm{~b}$ could mediate significant signaling functions and induce opsonophagocytosis of targeted cells and particles through interacting with the complement receptors CR1, CR2, and CR3, which are critical in host defense and homeostasis [15, 16, 95-98]. It was reported that apoptotic cells could induce complement activation and the generation of $\mathrm{C} 3 \mathrm{~b} / \mathrm{iC} 3 \mathrm{~b}[99,100] . \mathrm{C} 3 \mathrm{~b} / \mathrm{iC} 3 \mathrm{~b}$ was deposited on apoptotic and necrotic cells and apoptotic bodies, which facilitated the phagocytosis and removal of the cells or particles by macrophages expressing the receptors CR1 and CR3 [101, 102]. In a mouse model of CCL4-induced liver injury, $\mathrm{C} 3 \mathrm{~b} / \mathrm{iC} 3 \mathrm{~b}$ was deposited in damaged liver parenchyma. $\mathrm{C} 3 \mathrm{~b} / \mathrm{iC} 3 \mathrm{~b}$ deficiency caused by genetic knock-out $\mathrm{C} 3$ or complement depletion via CVF treatment led to a slow removal of damaged tissue and impaired regeneration after 72 hours of injury [103]. In a mouse model of Clostridium difficile-induced intestinal damage, $\mathrm{C} 3 \mathrm{~b}$ exerted the function of opsonization and promoted the phagocytosis of bacteria by neutrophils [104]. These results suggested that the involvement of $\mathrm{C} 3 \mathrm{~b} / \mathrm{iC} 3 \mathrm{~b}$ in the elimination of pathogens or injured tissue contributed to tissue repair and recovery after injury. Apart from mediating phagocytosis under pathological conditions, $\mathrm{C} 3 \mathrm{~b} / \mathrm{iC} 3 \mathrm{~b}$ was beneficial for embryo development. Oviductal cell-derived $\mathrm{C} 3 \mathrm{~b} / \mathrm{iC} 3 \mathrm{~b}$ enhanced the size of blastocysts and the rate of hatching, promoting embryo development and reproduction in mice [105]. In human and mouse multiple sclerosis, deposited $\mathrm{C} 3 \mathrm{~b} / \mathrm{iC} 3 \mathrm{~b}$ was implicated in microglia priming and in the acceleration of the progression of the disease [106]. These findings suggest that blocking the interaction of $\mathrm{C} 3 \mathrm{~b} / \mathrm{iC} 3 \mathrm{~b}$ with microglia may be a unique therapeutic approach to neurodegenerative disease. However, to date, the role of $\mathrm{C} 3 \mathrm{~b} / \mathrm{iC} 3 \mathrm{~b}$ in ischemic stroke is largely unknown. Studies focusing on the relationship between $\mathrm{C} 3 \mathrm{~b} / \mathrm{iC} 3 \mathrm{~b}$-mediated phagocytosis and the outcomes in ischemic stroke are also scarce.

\subsection{CR1 in ischemic stroke}

CR1 is a single-chain membrane-bound glycoprotein expressed predominantly on blood cell types, of which $>80 \%$ of CR 1 is dedicated to erythrocytes [107-110]. It is a receptor for $\mathrm{C} 3 \mathrm{~b}$ and $\mathrm{C} 4 \mathrm{~b}$ [111]. In the periphery, CR1 is known to play several pivotal roles; one important function is capturing and clearing $\mathrm{C} 3 \mathrm{~b} / \mathrm{C} 4 \mathrm{~b}$-opsonized pathogens or immune complexes via their transport to the liver or spleen $[111,112]$. Failure to clear the immune complex leads to the deposition of complexes in tissues and activation via $\mathrm{Fc}$ receptors, resulting in tissue injury. CR1 expressed on certain leukocytes could also promote phagocytosis of complement-opsonized cells [113]. 
The expression and distribution of CR1 in humans and rodents is different because human CR1 is encoded by a separate gene to human CR2, while murine CR2 encodes both CR1 and CR2 [114-116]. In the CNS of humans, the function of CR1 has not been well established because even the presence of CR 1 in the human brain is limited and conflicted [115, 117-120]. Recent studies showed that CR1 mRNA could be detected in the cortex and cerebellum of Alzheimer's disease (AD) patients but in very low amounts [121-123]. Recent Genome Wide Association Studies (GWAS) have identified that CR1 is strongly implicated in the progression of AD [124-128]. An in vitro study showed that CR1 expressed on microglia was increased after microglia activation induced by lipopolysaccharide (LPS). The antibody blockage of CR1 enhanced microglial phagocytosis of dextran beads under Amyloid- $\beta 42$ treatment. In addition, the blockage of CR1 on microglia following LPS or amyloid- $\beta 42$ treatment prevented neuronal death induced by conditioned medium from LPS- or Amyloid- $\beta$ 42-stimulated microglia [129]. This study suggested that microglial CR1 was detrimental to neurons in the pathology of $\mathrm{AD}$. However, in the pathological process of ischemic stroke, the role of CR1 is still unknown. More studies need to be performed in the future to elucidate the function of CR1 in ischemic stroke.

\section{4. $\quad \mathrm{CR} 2$ and $\mathrm{SCR} 2$ in ischemic stroke}

In the immune system, CR2 (CD21) is primarily expressed on B cells, dendritic cells, and a subset of T cells $[113,116,130,131]$. CR2 is a key part of the B cell antigen receptor complex together with CD19, CD81, and CD225. It has been known to result in a more efficient humoral immune response via binding to its ligands, mainly including the breakdown products of $\mathrm{C} 3 \mathrm{~b}$ (iC3b, $\mathrm{C} 3 \mathrm{dg}$, and C3d) and antigen-bound IgM [132]. CR2 was also found to play a role in B cell differentiation, selection, maintenance and elimination of self-reactive B cells [133]. Variations or deletions of the CR2 gene in humans or in mice are associated with a variety of autoimmune and inflammatory conditions, such as systemic lupus erythematosus (SLE) and chronic variable immunodeficiency (CVID) [116]. However, in the CNS, the function of CR2 is still unclear. Previously, the expression of CR2 was found in human glioma cells and fetal astrocytes, but its expression in mouse brains was much lower [117, 134]. Recently, CR2 was shown to be expressed in neural progenitor cells and to regulate hippocampal neurogenesis. A lack of CR2 in young and old CR2 knock-out mice increased basal neurogenesis compared with wildtype littermates, while the intracerebral injection of the CR2 ligand of C3d reduced the proliferating neuroblasts in wildtype mice but not in CR2 knock-out mice [134]. In another study, a genetic depletion of CR2 in mice improved neurological outcomes and reduced mortality after traumatic brain injury. In addition, deficiency of the CR2 gene also attenuated $\mathrm{C} 3$ and $\mathrm{IgM}$ deposition in the brain, as well as inhibited astrocytosis and microglial activation at 7 days post-injury [135]. In a mouse model of spinal cord injury, CR2 was upregulated in the spinal cord after 7 days of injury. CR2 deficiency led to an increased loss of synaptic nerve terminals following nerve injury. An in vitro study showed that astrocytes were the main cell type expressing CR2 [136]. These studies suggested that CR2 plays a functional role in the response to tissue injury, as least in a mouse model of closed head injury and spinal cord injury.

In regard to ischemic stroke, the role of CR2 in the brain has been scarcely investigated until now. However, it has largely been known as a potential therapeutic vehicle by linking complement-inhibitory proteins, such as Crry, $\mathrm{fH}$, and $\mathrm{CD} 59$, to inhibit complement activation in various diseases, such as collagen antibody-induced arthritis, ischemia reperfusion injury, acute lung ischemia reperfusion injury, cardiac ischemia reperfusion injury, and cerebral ischemic injury [5, 61, 130, 137-141]. Crry inhibits all complement pathways at the $\mathrm{C} 3$ activation step, fH inhibits only the alternative pathway, and CD59 inhibits generation of the terminal membrane attack complex (MAC, C5b-9) [61, 142, 143]. Therefore, the different fusion variations of the complement inhibitors, namely, CR2-Crry, CR2-fH, and CR2-CD59, make it possible to determine the role and contribution of certain complement pathways and activation products in disease processes.

In a mouse model of $60 \mathrm{~min}$ transient cerebral ischemia, a treatment of CR2-Crry via tail injection improved neurological outcomes, reduced neutrophil influx in the brain, and increased blood flow after reperfusion [68]. In the same model in mice, another study investigated the effect of either CR2-Crry or CR2-fH treatment on outcomes after ischemic stroke. The results showed that CR2-Crry treatment reduced brain infarct volume and neurological deficit after ischemia but did not show a protective effect after ischemia. Furthermore, CR2-fH treatment displayed persistent neuroprotective function, as both reduced ischemic brain injury and improved neurological function after ischemia were observed [5]. In fact, a previous study also found that CR2-fH treatment mediated protection from cerebral injury until 7 days post-reperfusion in mice [138]. Thus, the alternative pathway of complement activation possibly played a detrimental role for a relatively longer period during the pathophysiological process of ischemic stroke. Inhibiting all the pathways of complement activation via CR2-Crry treatment is not the best option for reducing complement-related ischemic brain injury 
because it affects the subsequent tissue regeneration after ischemic stroke. The role of CR2-CD59 has been reported in a mouse model of choroidal neovascularization $(\mathrm{CNV})$, where it contributes to emolliating the severity of choroidal neovascularization [144]. However, the effectiveness of CR2-CD59 treatment for ischemic stroke has not yet been clarified.

The soluble form of CR2, sCR2, has been demonstrated to shed from human B cells, T cells, and lymphocytes and is present in the circulation [145-148]. Decreased sCR2 levels in the circulation were shown in multiple autoimmune diseases, such as multiple sclerosis, systemic sclerosis, and rheumatoid arthritis [149, 150]. A recent study found that the level of sCR2 was elevated in the cerebrospinal fluid of multiple sclerosis patients and correlated with the severity of the disease. Furthermore, an in vitro study showed that sCR2 inhibited the cleavage of $\mathrm{C} 3$ into iC3b, which mediated the clearance of debris from the inflammatory site [151-153]. These findings suggest a novel function of sCR2 in human neuroinflammation. In the pathogenesis of ischemic stroke, the change and function of sCR2 is unclear and warrants comprehensive investigation in the future to discover new targets for the treatment of ischemic stroke.

\subsection{C3aR in ischemic stroke}

$\mathrm{C} 3 \mathrm{aR}$ is the receptor of $\mathrm{C} 3 \mathrm{a}$ and belongs to the rhodopsinfamily of seven transmembrane domain G-proteincoupled receptors $[154,155]$. C $3 \mathrm{aR}$ is expressed not only in cells of the myeloid lineage (monocytes, macrophages, eosinophils, basophils) but also in many tissues and cell types outside of the immune system [39, 156-158]. There are several differences in the $\mathrm{C} 3 \mathrm{aR}$ expression patterns between humans and rodents. Human neutrophils, mast cells, and endothelial cells express $\mathrm{C} 3 \mathrm{aR}$, while no data support the C3aR expression in these cells in mice [159, 160]. In addition, various stem and progenitor cells were shown to express $\mathrm{C} 3 \mathrm{aR}$, including hematopoietic stem cells, mesenchymal stem cells, neural stem cells, and dental pulp progenitor cells [67, 161-163]. One study reported that $\mathrm{C} 3 \mathrm{aR}$ was necessary for basal neurogenesis. Mice lacking $\mathrm{C} 3 \mathrm{aR}$ or mice treated with a $\mathrm{C} 3 \mathrm{aR}$ antagonist reduced $\mathrm{DCX}^{+} / \mathrm{BrdU}^{+}$cells in the subventricular zone (SVZ), the dentate gyrus subgranular zone (SGZ) of the hippocampus, and the olfactory bulb (OB) [67].

In the CNS, microglia, astrocytes, oligodendrocytes, and neurons express $\mathrm{C} 3 \mathrm{aR}$, among which the neurons were identified as the principle cell type expressing C3aR under physiological conditions [164-167]. It has been shown that C3aR is involved in chick eye morphogenesis and rat cerebellar cortex histogenesis during development and facilitates mouse skeletal muscle regeneration after cardiotoxin-induced muscle injury [168-170]. However, in multiple CNS diseases, C3aR expression was increased in the brain, contributing to the exacerbation of inflammation and disease progression. For example, $\mathrm{C} 3 \mathrm{aR}$ was implicated in the pathophysiology of major depressive disorder (MDD) [171]. C3aR expression increased in the prefrontal cortex of depressed suicide specimens and in mice with stress-induced depressivelike behavior. $\mathrm{C} 3 \mathrm{aR}$ genetic knock-out inhibited $\mathrm{C} 3 \mathrm{aR}^{+}$ monocyte infiltration into the brain and reduced the levels of the pro-inflammatory cytokine IL- $1 \beta$ in the prefrontal cortex after chronic stress. In addition, deficiency of C3aR prevented chronic stress-induced behavior despair. In a mouse model of $\mathrm{AD}, \mathrm{C} 3$ and $\mathrm{C} 3 \mathrm{aR}$ expression levels were upregulated and specifically expressed in astrocytes and microglia in the brain, respectively [172]. Depletion of $\mathrm{C} 3 \mathrm{aR}$ through genetic knock-out or C3aR antagonist treatment in microglia reversed the ability of microglia phagocytosis under chronic C3 stress. C3aR antagonist treatment in $\mathrm{AD}$ mice reduced plaque load and microgliosis in the brain. The study indicated that microglial $\mathrm{C} 3 \mathrm{aR}$ together with $\mathrm{C} 3$ mediated $\beta$-amyloid pathology and neuro-inflammation in an $\mathrm{AD}$ mouse model [172]. In regard to ischemic brain injury, it was reported that $\mathrm{C} 3 \mathrm{aR}$ was expressed on endothelial cells, microphage-like cells, and astrocytes, displaying upregulation after 6 hours to 2 days of focal ischemia in mice [173]. Using a mouse transient or permanent MCAO model, C3aR was implicated in the recruitment of neutrophils to the infarct zone and exacerbated tissue injury; however, this effect depended on blood reperfusion, as the protective effect of intraperitoneal $\mathrm{C} 3 \mathrm{aR}$ antagonist on reducing brain infarct volume and inflammatory cell infiltration in the brain was not observed in animals after permanent MCAO [174]. In contrast, in a neonatal rat model of hypoxic-ischemic brain injury, the intranasal or lateral cerebral ventricle injection of $\mathrm{C} 3 \mathrm{a} 1$ hour after brain injury could attenuate tissue loss and memory impairment 41 days after brain injury in wild-type mice compared to $\mathrm{C} 3 \mathrm{aR}$ genetic knock-out mice [82, 83]. These studies suggested that $\mathrm{C} 3 \mathrm{a} / \mathrm{C} 3 \mathrm{aR}$ exerted a protective role in the pathogenesis of hypoxic-ischemic brain injury in neonatal rats. One of the reasons causing the conflicting results of the role of $\mathrm{C} 3 \mathrm{aR}$ in brain ischemic injury could be the different pathological process between transient MCAO and hypoxic-ischemic brain injury. The other reason could be the different susceptibility of cerebral ischemia in adult and neonatal animals. In addition, all studies mentioned above mainly focused on the role of $\mathrm{C} 3 \mathrm{aR}$ in the acute phase of cerebral ischemia, but the function of $\mathrm{C} 3 \mathrm{aR}$ in the subacute and chronic phases of ischemic stroke is still unknown and needs to be further investigated. 
In addition to its role in ischemic stroke, C3aR was also reported to be implicated in the progression of thoracic aortic dissection and myocardial infarction, which are also vascular diseases $[175,176]$. In a model of brain inflammation induced by LPS injection, the results showed that $\mathrm{C} 3 \mathrm{aR}$ played a critical role in endothelial activation and leukocyte recruitment when LPS was injected into the brain [177]. In a mouse model of laserinduced macular degeneration, the presence of $\mathrm{C} 3 \mathrm{aR}$ was associated with increased detrimental angiogenesis in the retina [178]. This study showed that C3aR has a close link with the function of endothelial cells and angiogenesis under pathological conditions. However, whether $\mathrm{C} 3 \mathrm{aR}$ affects the function of endothelial cells and angiogenesis after ischemic stroke remains unclear. The dysfunction of endothelial cells could result in a variety of severe events, such as the impairment of the integrity of the blood brain barrier (BBB) and angiogenesis, both of which play an important role in post-stroke recovery. Therefore, investigating the role of $\mathrm{C} 3 \mathrm{aR}$ on the integrity of $\mathrm{BBB}$ and angiogenesis after ischemic brain injury is also warranted and would be helpful for uncovering the novel function of $\mathrm{C} 3 \mathrm{aR}$ during ischemic stroke.

\subsection{CR3 in ischemic stroke}

\subsubsection{Introduction of CR3}

CR3, also called $\alpha \mathrm{M} \beta 2, \mathrm{CD} 11 \mathrm{~b} / \mathrm{CD} 18$, or Mac-1, belongs to the integrin $\beta 2$ subfamily. CR3 is functionally composed of CD11b ( $\alpha$-chain) and CD18 ( $\beta$-chain) [179]. It was noted that $\mathrm{CD} 11 \mathrm{~b}$ is the key subunit mediating the biological functions of CR3 and is encoded by the ITGAM gene in humans, while CD18 is a common subunit shared with the other three members of the integrin $\beta 2$ subfamily, including CD11a/CD18, gp150/95 (CD11c/CD18), and CD11d/CD18 [179, 180]. CR3 is highly expressed in most myeloid and lymphoid cells in both humans and rodents [181]. CR3 exhibits broad ligand recognition specificity and has more than 40 reported protein ligands, which explains the complexity of CR3mediated functions $[182,183]$. It is widely accepted that CR3 mediates the adhesive reaction of leukocytes during the inflammatory response and particularly promotes the migration of neutrophils to sites of inflammation [184186]. CR3, especially the subunit CD11b, mediates the mobility of neutrophils, which is beneficial for controlling infection [187]. CR3 was also shown to suppress inflammation by affecting pro-inflammatory signaling pathways, such as the toll-like receptor (TLR) and Fc $\gamma R$ signaling pathways [188-191]. For example, CD11b on leukocytes was rapidly activated after TLR stimulation [180, 192, 193]. Activated CD11b on macrophages induced the intracellular activation of Src and Syk, which phosphorylated MyD88 and TRIF and eventually led to reduced activation of the transcription factor NF- $\kappa \mathrm{B}$ and the production of pro-inflammatory proteins. By contrast, a deficiency of $\mathrm{CD} 11 \mathrm{~b}$ in macrophages reversed this phenomenon [189]. The inhibition of the production of pro-inflammatory cytokines was also observed on NK cells pretreated with CR3-specific agonists under TLR stimulation [191]. These studies suggested that CR3 could negatively regulate inflammation induced by TLRdependent pathway activation.

Another CR3 function is enhancing phagocytosis, which is also the main role of CR3 [181]. CR3 was first demonstrated to induce phagocytosis via the interaction between the subunit CD11b and its ligand iC $3 b$. These activated fragments exist during complement pathways, and is the reason why CR3 is named as a complement factor [194, 195]. Under pathophysiological conditions, cells expressing CR3 could phagocytize iC $3 b$ opsonized bacteria, apoptotic cells and immune complexes, which was essential in limiting the unwanted inflammatory immune response [196-199]. In addition, the interaction between CR3 and iC $3 \mathrm{~b}$ also contributed to the release of anti-inflammatory cytokines such as IL-10 and TGF- $\beta$ [200]. CR3 was also involved in the pathogenesis of systemic lupus erythematosus. A single nucleotide polymorphism in the CD11b chain (rs1143679) could impair CR3-mediated phagocytosis in monocytes and monocyte-derived macrophages isolated from patients with this mutation [201, 202].

\subsubsection{The role of CR3 in the CNS}

Numerous studies have demonstrated that CR3-mediated phagocytosis is critical during CNS development, for the homeostasis of the microenvironment in the brain, and for repair and regeneration after injury [25, 203-206]. CR3 was spatially expressed next to synapses and played a crucial role in synaptic pruning and plasticity during brain development [115, 207, 208]. In the CNS, microglia were the only cell type expressing CR3 and exerted a phagocytosis function under pathophysiological conditions $[115,207,209,210]$. In the postnatal retinogeniculate system, microglia phagocytized presynaptic inputs during peak synaptic pruning, which depended on neuronal activity and the CR3/C3 phagocytic signaling pathway. Blocking the interaction between microglia-specific CR3 and C3 led to sustained deficits in synaptic connectivity and the removal of extranumerary synaptic inputs [211, 212]. This study further supported the significant role of microglia-specific CR3 in synaptic remodeling during development. However, the CR3-mediated phagocytosis of synapses was involved in the pathogenesis of $\mathrm{AD}$ in animal experiments. $\mathrm{AD}$ mice lacking $\mathrm{CR} 3$ showed less 
phagocytic synapses in microglia and improved synaptic function in the brain. Inhibiting CR3 activity could reverse synaptic loss and dysfunction during the pathology of AD [213]. Deficiency of the CR3-related adapter protein in $\mathrm{AD}$ mice could attenuate the severity of neurotic dystrophy and learning deficits [214]. In addition, clinical studies found that the mutation of microglia-specific receptors such as TREM2, CD33, and CR3 were associated with increased risks for developing AD [215]. Thus, therapeutic targeting of CR3 and microglia activation at the early stage may reduce synaptic loss and hinder the progression of AD. Despite the detrimental effect of CR3-mediated phagocytosis on synapses, it was also found that CR3 could uptake fibrillary amyloid- $\beta$ (fA $\beta$ ) in microglia both in vitro and in vivo, which contributed to the clearance of $\mathrm{A} \beta$ during $\mathrm{AD}$ progression [216]. By contrast, a recent study uncovered a distinct mechanism of microglia-specific CR3 on modulating the $A \beta$ levels in the brain [217]. In a mouse model of $A D$, the genetic knock-out of $C R 3$ caused increased $A \beta$ accumulation in the brain compared to the wide-type mice. The in vitro study also showed that microglia with CR3 depletion displayed higher efficiency at degrading extracellular $A \beta$ by secreting enzymatic factors than that of wild-type cells [217]. This study provides novel insight into the CR3- and microgliamediated removal of brain $\mathrm{A} \beta$ in $\mathrm{AD}$, which is independent of phagocytosis.

\subsubsection{The role of CR3 in ischemic stroke}

CR3 could be directly activated under a variety of neuroinflammatory stimulations [218]. After ischemic stroke, $\mathrm{CD} 11 \mathrm{~b}$, the subunit of CR3, was upregulated in the brain and was commonly recognized as a marker for microglia activation [219-221]. CD11b was also used to define bone marrow derived macrophages and $\mathrm{CD} 11 \mathrm{~b}^{+}$macrophages were involved in impairing neovascularization in ischemic muscle in aged mice [222]. Generally, CR3mediated phagocytosis was beneficial for clearing debris, apoptotic or necrotic neurons, immature synapses, or degenerated tissue and limiting inflammation after injury $[25,179,207,223,224]$. However, the precise function of CR3 and its mediated phagocytosis was not completely investigated during cerebral ischemia. Several studies used mice with the genetic depletion of CD11b or CR3 to explore the role of CR3 in the pathological process of ischemic stroke, but it is still controversial whether CR3 exerts protective or detrimental effects after cerebral ischemia. Using CD11b-thymidine kinase mutant-30 $\left(\mathrm{TK}^{\mathrm{mt}-30}\right)$ transgenic mice, in which $\mathrm{CD} 11 \mathrm{~b}^{+}$microglia were depleted in the brain after ganciclovir injection, a lack of $\mathrm{CD} 11 \mathrm{~b}^{+}$microglia resulted in increased apoptotic neurons and a larger infarct volume at 3 days after ischemia [225]. The results revealed a neuroprotective role of $\mathrm{CD} 11 \mathrm{~b}$ during ischemic stroke. However, the beneficial role of CR3 in the acute phase of ischemic stroke was challenged by another study in which anfibatide, the platelet glycoprotein (GP) receptor Ib $\alpha$ inhibitor, was used to treat ischemic stroke. The results showed that anfibatide injection 1-hour post-ischemic reperfusion inhibited the elevation of CR3 expression. This phenomenon was associated with reduced BBB damage, smaller brain infarct volume, and improved neurological functions after 24 hours of ischemia [226]. The detrimental role of CR3 in stroke-induced BBB damage and brain injury was supported by other studies. In a thrombotic stroke mouse model, CR3 deficiency protected from intracerebral hemorrhage induced by thrombolysis with tissue plasminogen activator (tPA) 5 hours after MCAO [227]. In a model of $90 \mathrm{~min}$ or $180 \mathrm{~min}$ MCAO, mice lacking CR3 showed less BBB permeability, less neutrophil infiltration, and reduced infarct volume after 24 hours of ischemia compared to wild-type mice $[227,228]$. The intravenous injection of $\mathrm{CD} 11 \mathrm{~b}$ or CD18 monoclonal antibodies in rats at 2-4 hours after transient cerebral ischemia also showed protective effects after 2 days and 7 days of cerebral ischemia $[229,230]$. Although these studies indicated that CR3 possibly acted as a deleterious factor for ischemic brain injury, it is still difficult to define the exact role of CR3 in the pathogenesis of cerebral ischemia, especially at the late stage of ischemic stroke. Although an antagonist of CR3, XVA143, has been used to curb CR3 activity in some studies, it is not available from the market, and no specific inhibitors for CR3 are available up to now [231-234]. This further increases the difficulty of studying the role of CR3 under pathological conditions. It was found that $\mathrm{CD} 11 \mathrm{~b}$ could be activated and sustained upregulation for a long time after cerebral ischemia; however, the study of the function of CD11b at the late phase of ischemic stroke is poorly understood [219]. In addition, although much evidence has shown microgliaspecific CR3-mediated synaptic remodeling or loss during development or in a variety of diseases, less is known about the relationship between CR3 activation and synaptic remodeling or loss in ischemic stroke. Further work focusing on the area will broaden our knowledge of CR3 in ischemic stroke. UK-279, 276, also referred to as recombinant neutrophil inhibitory factor, has been called a selective CR3 antagonist. It was found to bind to the Idomain of CD11b and inhibited neutrophil adhesion [235]. It has been shown to be helpful for attenuating acute ischemic brain injury at the early stage of stroke [236-238]. Therefore, it may be a potential tool for exploring CR3-mediated functions during the late phase of ischemic stroke. 


\subsection{C5, C5a, and C5b-9 in ischemic stroke}

\subsubsection{Introduction of C5, C5a and C5b-9}

C5 is considered to be at the center of complement activation and exerts biological activities after being cleaved into $\mathrm{C} 5 \mathrm{a}$ and $\mathrm{C} 5 \mathrm{~b}$ by either the classic or alternative pathway C5 convertases [239]. The C5 convertases (C4b2a3b and $\mathrm{C} 3 \mathrm{~b} 2 \mathrm{BbP}$ ) cleave $\mathrm{C} 5$ to a smaller active fragment of soluble complement factor $5 \mathrm{a}$ (C5a) and another larger fragment of membrane-bound complement factor $5 b$ (C5b) $[13,240]$. Similar to C3a and $\mathrm{C} 4 \mathrm{a}, \mathrm{C} 5 \mathrm{a}$ is also termed anaphylatoxin. C5a consists of 74 amino acids and induces the release of various mediators from mast cells and phagocytes, which in turn amplify inflammatory responses [240, 241]. C5a acts as a chemoattractant for cells such as neutrophils and monocytes to the sites of injury or inflammation and can increase the production of interferon gamma (IFN-r) [242]. Compared to C3a, C5a has a higher potency and obviously more biological action [243, 244]; it exerts multiple functions via binding to its receptors complement component 5a receptor 1 (C5aR1/C5aR/CD88) and complement component 5a receptor 2 (C5aR2/C5L2/GPR77) [10, 113, 245, 246]. Through the interaction with C5aR1 on polymorphonuclear leukocytes (PMNs), monocytes, and macrophages, C5a could induce the secretion of lysosomal enzymes and pro-inflammatory cytokines [247]. When binding to C5aR1 on neutrophils, C5a enhanced the adhesiveness and aggregation of neutrophils and promoted oxidative metabolism and the production of reactive oxygen species (ROS) in neutrophils [248, 249]. Unlike the interaction between $\mathrm{C} 5 \mathrm{a}$ and $\mathrm{C} 5 \mathrm{aR} 1$, the interaction between $\mathrm{C} 5 \mathrm{a}$ and $\mathrm{C} 5 \mathrm{aR} 2$ did not induce classical signaling (induction of intracellular calcium transients) or cause biological cellular responses [250]. The precise biological function of $\mathrm{C} 5 \mathrm{aR} 2$ remains unclear [113, 251-254]. C5aR2 appeared to be a non-signaling or potential decoy receptor for C5a [246, 255]. However, recent studies found that $\mathrm{C} 5 \mathrm{aR} 2$ acts as a functional receptor in sepsis, as $\mathrm{C} 5 \mathrm{aR} 2$ hindered the release of high mobility group box 1 (HMGB1) protein from macrophages; moreover, the blockage of $\mathrm{C} 5 \mathrm{aR} 2$ along with C5aR1 improved survival in sepsis compared to the blockage of either receptor alone [256]. Thus, the role of C5aR2 still awaits comprehensive investigation in the future [246].

C5b-9 is the membrane attack complex (MAC), which is also called the terminal complement complex (TCC) and is formed by $\mathrm{C} 5 \mathrm{~b}$ subsequently binding to complement factor 6 (C6), complement factor 7 (C7), complement factor 8 (C8) and complement factor 9 (C9). C5b-9 on the target surface could lead to cell lysis or cell activation, depending on the level of C5b-9 deposition on the cell surface [96, 113, 257-259]. The combined functions of C5a and C5b-9 are strongly responsible for the inflammation and tissue damage associated with excessive complement activation [10].

Clinical studies of C5, C5a and C5b-9 in ischemic stroke

A variety of genetic polymorphisms in complement genes have been shown to be linked to atherosclerosis, cardiovascular disease, and ischemic stroke [260, 261]. Among numerous genes, a polymorphism in the $\mathrm{C} 5$ gene (C5 rs17611) was the only independent risk factor for transient ischemic attack (TIA) or stroke and was associated with an increased incidence of stroke in patients with carotid atherosclerosis [262-264]. In addition, the polymorphism in the $\mathrm{C} 5$ gene was also related to higher plasma C5a levels and predicted increased incidence of stroke in patients with carotid atherosclerosis [262, 263].

In patients with acute ischemic stroke, both $\mathrm{C} 5 \mathrm{a}$ and C5b-9 changed in the plasma. A study of 15 acute ischemic stroke patients demonstrated that $\mathrm{C} 5 \mathrm{a}$ in the plasma began to increase at 7 days and was maintained at a plateau up to 14 days, while C5b-9 decreased after 1 and 2 days of ischemic stroke and showed no difference up to 28 days after ischemic stroke compared to the healthy control [48]. By contrast, another study recruiting 11 acute ischemic stroke patients found that, compared to the healthy control, the plasma C5b-9 was elevated at 72 hours, peaked at the $7^{\text {th }}$ day, and maintained at a plateau up to 12 days, which correlated to the infarct volume within a follow-up period of 12 months [265]. Utilizing severe carotid atherosclerosis as the control, a study recruiting 26 ischemic stroke patients did not find changes in plasma C5a. However, the level of plasma C5b-9 was significantly elevated and exhibited a positive correlation with the clinical severity of ischemic stroke and the level of functional disability [266]. Although these studies presented discrepant results regarding the changes in plasma C5a and C5b-9 in acute ischemic stroke, which may be due to the distinct severity of patients or the detection methods, it is no doubt that C5a and C5b-9 are activated during stroke pathophysiology. Studies recruiting a large scale of different subtypes of stroke are imperative to confirm the changes in plasma $\mathrm{C} 5 \mathrm{a}$ and C5b-9 in ischemic stroke and their correlation with the outcomes of stroke. These findings pave the foundation for the use of C5a and C5b-9 in the plasma as a predictor for the prognosis of ischemic stroke.

C5/C5a in experimental ischemic stroke 
C5 occupies a critical position within the complement cascade, as it could be generated through all three complement pathways [267]. The role of C5, even at the early stage of ischemic brain injury, remains unclear [268]. In a mouse model of $60 \mathrm{~min}$ transient MCAO, C5 genetic knock-out did not offer neuroprotection after ischemia [34]. Conversely, in a mouse permanent MCAO model, C5 deficiency both reduced brain infarct volume and attenuated neurological deficits after ischemia [269]. One possible explanation for the opposite results between the two studies was the difference in brain blood reperfusion. Systemic C5 inhibition via intravenous and intraperitoneal injection of anti-C5 monoclonal antibodies also prevented the deterioration of neurological functions by reducing cerebral lesion and edema after ischemic brain injury [270]. The lifelong deficiency of C5 via genetic knock-out could result in a constitutionally detrimental effect since completely acute C5 blockade might mask a potential benefit in the context of stroke. Therefore, focal or temporal $\mathrm{C} 5$ inhibition during the periischemic time period, instead of lifelong C5 deficiency, could be a better option for reducing the $\mathrm{C} 5$-mediated detrimental effects after ischemic stroke. Apart from acute ischemic brain injury, C5 was also activated and continued for a long time during the pathogenesis of chronic cerebral ischemia [271]. In a rat model of chronic cerebral hypoperfusion, $\mathrm{C} 5$ deposition in the corpus callosum was increased after 30 days of bilateral carotid artery stenosis. C5-deficient mice showed a decrease in white matter injury in the corpus callosum and fewer reactive astrocytes and microglia compared to the wildtype mice. This study focused on the role of $\mathrm{C} 5$ in chronic cerebral ischemia, illustrating the relationship between $\mathrm{C} 5$ deposition and chronic cerebral ischemia-induced white matter injury [271]. However, a direct causal role for C5 in the chronic phase of acute ischemic stroke was not assigned, which needs to be comprehensively investigated in the future.

The anaphylatoxin $\mathrm{C} 5 \mathrm{a}$, a split product of $\mathrm{C} 5$, is constantly produced during complement activation [272]. $\mathrm{C} 5 \mathrm{a}$ is a major pro-inflammatory mediator in a wide range of diseases because it regulates both the inflammatory process in innate immunity and the adaptive immune response [273]. C5a affects inflammation by inducing the release of cytokines and chemokines, upregulating adhesion molecule expression, and increasing vascular permeability [274, 275]. Furthermore, C5a is able to activate endothelial cells and induce caspase-dependent endothelium apoptosis in experimental lupus [276-278]. Numerous studies have shown that the generation of C5a and its interaction with the receptor $\mathrm{C} 5 \mathrm{aR} 1$ played a deleterious role in multiple diseases, including atherosclerosis, arthritis, renal ischemia-reperfusion injury, small intestine ischemia-reperfusion injury, mesenteric ischemia, myocardial ischemia, and ischemic stroke [272, 279-284]. In a mouse model of MCAO, C5a was upregulated after 1 day of ischemic stroke and predominantly generated by neurons in the brain [34, 285]. Blocking C5a signaling via genetic knock-out of $\mathrm{C} 5 \mathrm{aR} 1$ in mice improved neurological scores and reduced infarct size after 1 day of ischemic stroke. An in vitro study confirmed that cultured neurons expressed and upregulated $\mathrm{C} 5 \mathrm{a}$ expression under ischemic stress. Cultured astrocytes and microglia showed no elevation of C5 a expression under ischemic conditions. C5a treatment induced neuronal apoptosis under OGD conditions, while C5aR1 deficiency prevented neurons from OGD-induced apoptosis, suggesting that inhibiting the interaction between $\mathrm{C} 5 \mathrm{a}$ and $\mathrm{C} 5 \mathrm{aR} 1$ was neuroprotective in the acute phase of ischemic stroke [285]. Despite the overall body of evidence indicated that $\mathrm{C} 5 \mathrm{a}$ activation generated harmful effects during the early stage of ischemic stroke, $\mathrm{C} 5 \mathrm{a}$ possessed neuroprotective potential against glutamate-mediated neurotoxicity in mice [286, 287]. Therefore, it is possible that $\mathrm{C} 5 \mathrm{a}$ might act as a protective factor to inhibit tissue injury in the late phase of cerebral ischemia. Since the temporal course and functional significance of C5a during the progression of ischemic stroke have been extensively studied, the molecular mechanism of $\mathrm{C} 5 \mathrm{a}$ in ischemic stroke needs to be explored in the future.

\section{Experimental studies of C5b-9 in ischemic stroke}

C5b-9 is an end product during the complement cascade. In vitro studies showed that a sublytic dose of C5b-9, which did not cause cell death, induced proto-oncogenes, activated the cell cycle, and increased cell survival in oligodendrocytes [288]. C5b-9 prevented cultured oligodendrocytes from apoptotic cell death by inhibiting caspase- 3 and caspase- 8 activation and Bid cleavage and increasing Bcl-2 expression and cellular FLIP expression $[289,290]$. C5b-9 triggered the secretion of interleukin- 8 (IL-8) and monocyte chemoattractant protein-1 (MCP-1) from human umbilical vein endothelial cells [291]. Erythrocyte-derived C5b-9 could induce the constriction of cultured rat cerebral artery smooth-muscle cells, indicating that $\mathrm{C} 5 \mathrm{~b}-9$ could induce cerebral vasospasm [292]. These findings suggest that C5b-9 could play a role to some extent under pathophysiological conditions.

Indeed, in vivo animal studies proved that $\mathrm{C} 5 \mathrm{~b}-9$ was implicated in the pathogenesis of various diseases, including kidney ischemia-reperfusion and transplantation, spinal cord injury, traumatic brain injury, multiple sclerosis, AD and stroke [288, 293-295]. The involvement of C5b-9 in diseases was further supported by the observations of its deposition in patients. For example, C5b-9 was deposited in some cerebral arterial 
walls in the cerebral amyloid angiopathy [288]. In multiple sclerosis patients, C5b-9 presented in the brain within the plaques close to endothelial cells and adjacent to white matter [296]. In AD patients, deposition of C5b was noticed in the lesion area, which was associated with dystrophic neurites, neurofibrillary tangles, and $\mathrm{A} \beta$ deposits [297, 298].

Although it is apparent that there exists a relationship between C5b-9 expression and the pathogenesis of CNS disease, a pathological role for C5b-9 in stroke has not been defined. Deposition of C9, a marker for C5b-9 assembly, was determined in neurons in the infant brain with hypoxic-ischemic encephalopathy [299]. In a hypoxia-ischemia model in neonatal rats, C5b-9 was neurotoxic because the deficiency of $\mathrm{C} 9$ reduced brain infarct volume after 24 hours of stroke, while C9 administration reversed the result [300]. In a mouse model of transient cerebral ischemia, deficiency of C6, a member of C5b-9, did not prevent brain injury after 24 hours of reperfusion. Similarly, utilizing the same model, genetic knock-out of CD59a (a molecule that can inhibit the generation of C5b-9) did not affect the outcomes after 72 hours of reperfusion [138, 301]. However, in a mouse model of MCAO, the deficiency of CD59a increased brain infarct volume and exacerbated neurological deficit after 72 hours of ischemia [301]. These studies indicated that the function of C5b-9 during ischemic stroke may be dependent on the type and severity of insult.

\subsection{C5aR1 in ischemic stroke}

\subsubsection{Introduction of C5aR1}

C5aR1, known as CD88, is a $45 \mathrm{k}$-Da protein and belongs to the rhodopsin family of seven-transmembrane $\mathrm{G}$ protein-coupled receptors (GPCRs) [159, 302]. It is the primary receptor of $\mathrm{C} 5 \mathrm{a}$ and plays a pivotal role in proinflammatory and regulatory functions $[159,302]$. C5aR1 is mainly expressed in myeloid cells such as neutrophils, monocytes, macrophages, basophils and eosinophils [159]. Nonmyeloid cells, including NK cells, NKT cells, $\mathrm{T}$ cells, epithelial cells, endothelial cells, smooth muscle cells and neural cells, also express C5aR1 [303-310]. In both the human and mouse brain, C5aR1 is constitutively expressed in neurons and glial cells at a low level $[54,165$, 311-317]. However, under inflammation or disease states, in both human and experimental animal models, C5aR1 expression was greatly upregulated in astrocytes, microglia, and to a lesser extent on endothelial cells [54, 173, 308]. Increased C5aR1 expression was reported in Huntington disease, allergic encephalomyelitis, pyogenic granulomas of human skin [318-320], the CNS during inflammation [166, 308, 321], amyotrophic lateral sclerosis [322], closed head injury [323], and ischemic stroke [173].

\subsubsection{The role of C5aR1 in brain development}

Accumulated evidence has shown that C5aR1 is implicated in brain development. C5aR1 is transiently expressed on rat cerebellar granule neurons, with intense expression at 12 days but disappearance at 30 days after birth. An in vitro study confirmed C5aR1 expression in cerebellar granule neurons, and the expression was increased during neuronal differentiation and maturation. C5aR1 agonist treatment could prevent cultured cerebellar granule cells from serum deprivation-induced apoptosis, suggesting that $\mathrm{C} 5 \mathrm{aR} 1$ could provide antiapoptotic signaling to granule neurons during brain development [312]. The role of C5aR1 during development was further supported by another study. The injection of a C5aR1 agonist at the surface of the cerebellum promoted the proliferation of immature neurons and enlarged the thickness of the external granule cell layer (EGL) [168]. The contribution of C5aR1 to CNS development is not restricted to the cerebellum. For example, C5aR1 is expressed in presynaptic terminals of mossy fibers within the hippocampal CA3 region, suggesting a role for $\mathrm{C} 5 \mathrm{aR} 1$ in synaptic/cellular plasticity [324]. More recent data supported the beneficial role of $\mathrm{C} 5 \mathrm{aR} 1$ in neurogenesis in the brain $[325,326]$. C5aR1 was expressed in cultured neural progenitor cells and in the subventricular zone of the brain $[67,327]$. Blocking C5aR1 signaling via a selective C5aR1 antagonist PMX53 inhibited the proliferation of neural progenitor cells in the embryonic subventricular zone in vivo. Inhibition of C5aR1 also resulted in behavioral abnormalities in both sexes and MRI-detected brain microstructural alterations in adult male, suggesting that C5aR1 played a functional role in neurogenesis in mammals and provided mechanistic insight into complement-related brain disorders [327].

\subsubsection{The role of C5aR1 in diseases}

\section{The role of C5aRl in non-CNS disease}

The function of $\mathrm{C} 5 \mathrm{aR} 1$ in various diseases was explored using cells or tissues from $\mathrm{C} 5 \mathrm{aR} 1$ genetic knock-out mice or using a C5aR1 inhibitor or siRNA to inhibit C5aR1 expression [312, 328-331]. C5aR1 was implicated in a model of angiotensin II-induced hypertension. Genetic depletion of C5aR1 or pharmacologic inhibition of C5aR1 diminished hypertension-induced cardiac inflammation and remodeling [332]. In a mouse model of kidney ischemia, inhibiting C5aR1 via administering C5aR1 siRNA diminished neutrophil influx and cell necrosis in the renal tissue [333]. The protective effect of 
inhibiting C5aR1 during ischemic pathological conditions was demonstrated in a rat model of acute limb ischemiareperfusion, rodent intestinal ischemia-reperfusion, and rat hepatic ischemia-reperfusion [334-338]. These studies demonstrated that pretreatment with a C5aR1 antagonist could diminish the production of inflammatory cytokines and prevent local and remote organ injury after ischemia [334-337]. The above studies suggest that C5aR1 plays a crucial role in mediating the inflammatory response under pathological conditions. The selected C5aR1 antagonist could be a worthwhile option to attenuate the inflammatory response and exert beneficial effects in multiple disorders, especially ischemia-reperfusion injury.

\section{The role of C5aR1 in CNS disease}

C5aR1 antagonist treatment could block neutrophil extravasation into the brain parenchyma after traumatic brain injury or intracerebral hemorrhage, contributing to reduced tissue damage and improved spatial memory after brain injury [338, 339]. The positive effect of C5aR1 inhibition on outcomes was found in an animal AD model. Genetic knock-out of C5aR1 or the specific C5aR1 antagonist reduced fibrillary plaque accumulation, inhibited microglial inflammatory polarization, and suppressed cognitive loss in mice [331, 340]. However, the molecular mechanism of C5aR1 and its downstream effector in the ischemic brain is unclear. Several studies have shown that $\mathrm{C} 5 \mathrm{aR} 1$ expression is upregulated during ischemic brain injury. In a mouse model of permanent focal ischemia, C5aR1 mRNA expression was increased after 3 hours up to 21 days post-ischemia. C5aR1 was located on endothelial cells after 12 hours of ischemia and strongly expressed on reactive astrocytes and macrophage-like cells in the peri-infarct region of the ischemic cortex after 7 days of ischemia [173]. The elevation of $\mathrm{C} 5 \mathrm{aR} 1$ expression in the ischemic brain within 24 hours of ischemia was similar in rodents. Increased C5aR 1 was primarily observed in the meninges and outer cerebral cortex and on neurons in the granular layers after arterial occlusion [341]. In a mouse model of 1-hour MCAO, C5aR1 deficiency or C5aR1 antagonist treatment reduced brain infarct volume and improved neurological function. C5aR1 deficiency or C5aR1 antagonist treatment also protected cultured neurons from OGD-induced apoptosis [341]. In a rat model of hypoxicischemic encephalopathy, C5aR1 was predominantly expressed in microglia. Therapeutic hypothermia (HT) combined with the inhibition of the expression of C5aR 1 could reduce brain infarct volume within 3 days of brain ischemia [342]. These studies suggested that C5aR1 activation resulted in deleterious consequences at the early phase of ischemic brain injury, raising an opportunity to use specific C5aR1 antagonists to modulate complement activation and attenuate acute ischemic brain injury in humans. Although the time course of C5aR1 expression was examined and its detrimental role at the early stage of ischemic stroke was demonstrated, the role of C5aR 1 in the recovery process has not yet been explored. Future studies should allocate more effort to elucidate the role of C5aR1 at the later stage of cerebral ischemia, which provides new insights into potential strategies targeting C5aR1 during ischemic stroke.

\subsection{C5aR2 in ischemic stroke}

$\mathrm{C} 5 \mathrm{aR} 2$, previously known as $\mathrm{C} 5 \mathrm{~L} 2$, is another receptor of $\mathrm{C} 5 \mathrm{a}$ and $\mathrm{C} 5 \mathrm{a}$ degradation product $\mathrm{C} 5 \mathrm{ades} A r g$, the predominant form of circulating C5a [245, 343]. C5aR2 has a similar structure and cellular expression pattern of C5aR1 and is often coexpressed with C5aR1 [252, 344]. However, unlike C5aR1, C5aR2 is unable to couple to heterotrimeric $\mathrm{G}$ proteins and does not trigger the intracellular $\mathrm{G} \alpha$ signal [345]. As a consequence, C5aR2 functioned as a decoy receptor and limited the C5a availability [346]. However, increasing evidence has shown that $\mathrm{C} 5 \mathrm{aR} 2$ is also a functional receptor and exerts both anti-inflammatory and pro-inflammatory effects in diverse disease models. C5aR2 deficiency led to enhanced inflammatory effects induced by $\mathrm{C} 5 \mathrm{a}$ in rodent models of complex lung injury, allergic contact dermatitis, experimental allergic asthma, anti-neutrophil cytoplasmic antibodies (ANCA), and crescentic glomerulonephritis, suggesting an anti-inflammatory role for C5aR2 in these models [347-351]. In contrast, the absence of $\mathrm{C} 5 \mathrm{aR} 2$ led to reduced inflammation in models of air pouch, acute lung injury, sepsis and renal ischemiareperfusion injury in mice [256, 352-354]. Notably, $\mathrm{C} 5 \mathrm{aR} 2$ was required for the production of proinflammatory mediators from human mast cells [355]. C5aR2 was also involved in the production of G-CSF in a mouse model of polymicrobial sepsis, which was characterized by acute inflammation [356]. Thus, the function of $\mathrm{C} 5 \mathrm{aR} 2$ was probably mediating inflammation and immunity [250]. Although great progress has been achieved in the study of $\mathrm{C} 5 \mathrm{aR} 2$ functions in vitro and in a variety of experimental animal models, little is known about its role in the CNS, including ischemic stroke. Therefore, the role of C5aR2, within and beyond the CNS, is a major area of complement research in the future [54].

\section{Therapeutic approaches against complement in ischemic stroke}

It is widely accepted that deregulated or excessive complement activation is involved in numerous diseases 
or pathological conditions, including ocular pathologies, kidney disease, hematological system disorder, cancer, neurodegenerative disorder, and ischemic stroke [94, 130, 357]. Thus, it spurred robust interest in the modulation of the complement system as a therapeutic option in drug discovery [43, 240, 358]. A large number of therapeutic strategies targeting various steps of the complement cascade were developed, including antibodies and fusion proteins, small interfering RNAs, aptamers, low- molecular-weight peptides, and non-peptide inhibitors [359-362]. Several agents that inhibit all or part of the complement system, such as $\mathrm{C} 1$ inhibitor (C1-INH), CVF, a C3aR antagonist, small or large molecule C5aR antagonists, and sCD59 could reduce ischemia/reperfusion brain injury [130, 239]. Next, we analyze the effect of different complement inhibitors and some possible mechanisms against ischemic brain injury.

Table 1. C1-INH treatment for ischemic stroke

\begin{tabular}{|c|c|c|c|c|c|c|c|}
\hline Animals & Stroke models & $\begin{array}{l}\text { Time of } \\
\text { administration }\end{array}$ & $\begin{array}{l}\text { Routes of } \\
\text { injection }\end{array}$ & $\begin{array}{l}\text { Time point of } \\
\text { observations }\end{array}$ & Outcomes & Mechanisms & Refs \\
\hline $\begin{array}{l}\text { C57BL/6 } \\
\text { mice }\end{array}$ & $1 \mathrm{~h} \mathrm{MCAO}$ & $\begin{array}{l}0.5 \mathrm{~h} \text { before } \\
\text { or } 6 \mathrm{~h} \text { after } \\
\mathrm{MCAO}\end{array}$ & $\begin{array}{l}\text { Intravenous } \\
\text { injection with } \\
\text { IVIg or alone }\end{array}$ & $\begin{array}{ll}72 & \text { h } \\
\text { MCAO }\end{array}$ & $\begin{array}{l}\text { Reduced brain } \\
\text { infarction size, } \\
\text { neurological } \\
\text { deficit and } \\
\text { mortality }\end{array}$ & $\begin{array}{l}\text { Reduced deposition of } \\
\text { C3b and downregulated } \\
\text { excessive TLR2 and p- } \\
\text { JNK1 expression in the } \\
\text { brain }\end{array}$ & [400] \\
\hline $\begin{array}{l}\mathrm{C} 57 \mathrm{BL} / 6 \\
\text { mice } \\
\& \mathrm{CD} \text { rats }\end{array}$ & $\begin{array}{l}1 \mathrm{~h} \mathrm{MCAO} \text { (mice) } \\
\& 1.5 \mathrm{~h} \mathrm{MCAO} \\
\text { rats) }\end{array}$ & $\begin{array}{l}1 \mathrm{~h} \text { or } 6 \mathrm{~h} \text { after } \\
\mathrm{MCAO}\end{array}$ & $\begin{array}{l}\text { Intravenous } \\
\text { injection }\end{array}$ & $\begin{array}{lr}24 \mathrm{~h} \text { and } 7 \\
\text { days } \\
\text { MCAO }\end{array}$ & $\begin{array}{l}\text { Reduced infarct } \\
\text { volumes and } \\
\text { improved } \\
\text { clinical scores }\end{array}$ & $\begin{array}{l}\text { Reduced blood-brain } \\
\text { barrier damage, edema } \\
\text { formation, and } \\
\text { inflammation }\end{array}$ & {$[366]$} \\
\hline $\begin{array}{l}\text { Sprague- } \\
\text { Dawley } \\
\text { rats }\end{array}$ & $\begin{array}{l}\text { pMCAO } \\
\text { or thromboembolic } \\
\text { stroke }\end{array}$ & $\begin{array}{l}2 \mathrm{~h} \text { or } 4 \mathrm{~h} \text { after } \\
\mathrm{MCAO}\end{array}$ & $\begin{array}{l}\text { Intravenous } \\
\text { injection with } \\
\text { tPA or alone }\end{array}$ & $\begin{array}{ll}24 & \mathrm{~h} \\
\mathrm{MCAO} & \text { after }\end{array}$ & $\begin{array}{l}\text { Reduced } \\
\text { intracranial } \\
\text { hemorrhage and } \\
\text { neurological } \\
\text { scores }\end{array}$ & Not studied & [428] \\
\hline $\begin{array}{l}\mathrm{C} 57 \mathrm{Bl} / 6 \\
\text { mice }\end{array}$ & $\begin{array}{l}0.5 \mathrm{~h} \text { MCAO or } \\
\text { pMCAO }\end{array}$ & $\begin{array}{l}0 \mathrm{~h}, 3 \mathrm{~h}, 6 \mathrm{~h} \text {, or } \\
18 \mathrm{~h} \text { after } \\
\mathrm{MCAO}\end{array}$ & $\begin{array}{l}\text { Intravenous } \\
\text { injection }\end{array}$ & $\begin{array}{l}48 \mathrm{~h} \text { and } 7 \\
\text { days } \\
\text { MCAO after }\end{array}$ & $\begin{array}{l}\text { Reduced brain } \\
\text { infarct volumes } \\
\text { and } \mathrm{CD} 45^{+} \text {cell } \\
\text { infiltration in the } \\
\text { brain }\end{array}$ & Not studied & [367] \\
\hline CD1 mice & $2 \mathrm{~h} \mathrm{MCAO}$ & $\begin{array}{l}\text { Immediately } \\
\text { after ischemia }\end{array}$ & $\begin{array}{l}\text { Intravenous } \\
\text { injection }\end{array}$ & $\begin{array}{ll}48 & \text { h } \\
\text { MCAO }\end{array}$ & $\begin{array}{l}\text { Attenuated } \\
\text { general and } \\
\text { focal } \\
\text { neurological } \\
\text { deficits }\end{array}$ & $\begin{array}{l}\text { Reduced TNF-a, IL-18, } \\
\text { ICAM-1 and P-selectin } \\
\text { mRNA expression and } \\
\text { microglia activation; } \\
\text { Enhanced IL-6 and IL- } \\
10 \text { mRNA expression }\end{array}$ & [369] \\
\hline C57BL/6 & $0.5 \mathrm{~h} \mathrm{MCAO}$ & $\begin{array}{l}15 \text { min after } \\
\text { ischemia }\end{array}$ & $\begin{array}{l}\text { Intravenous } \\
\text { injection }\end{array}$ & $\begin{array}{l}4 \text { days after } \\
\text { MCAO }\end{array}$ & $\begin{array}{l}\text { Reduced general } \\
\text { and focal } \\
\text { neurological } \\
\text { deficit scores } \\
\text { and neuronal } \\
\text { degeneration }\end{array}$ & $\begin{array}{l}\text { Reduced } \mathrm{CD}^{4} 5^{+} \text {cell } \\
\text { infiltration in the brain }\end{array}$ & [33] \\
\hline CD1 mice & $2 \mathrm{~h} \mathrm{MCAO}$ & $\begin{array}{l}15 \text { min after } \\
\mathrm{MCAO}\end{array}$ & $\begin{array}{l}\text { Intravenous } \\
\text { injection }\end{array}$ & $\begin{array}{lr}48 & \text { h } \\
\text { MCAO after }\end{array}$ & $\begin{array}{l}\text { Reduced infarct } \\
\text { volume and } \\
\text { neuronal death }\end{array}$ & $\begin{array}{l}\text { Did not affect astrocyte } \\
\text { response }\end{array}$ & [364] \\
\hline Wistar rats & $1 \mathrm{~h} \mathrm{MCAO}$ & $\begin{array}{l}\text { Just } \quad \text { before } \\
\text { MCAO }\end{array}$ & $\begin{array}{l}\text { Intravenous } \\
\text { injection }\end{array}$ & $\begin{array}{lr}48 & \text { h } \\
\text { MCAO after }\end{array}$ & $\begin{array}{l}\text { Reduced infarct } \\
\text { volume and } \\
\text { leukocyte } \\
\text { infiltration in the } \\
\text { brain }\end{array}$ & Not studied & [429] \\
\hline
\end{tabular}




\subsection{Inhibition of complement initiation}

\subsubsection{C1-INH}

It is the interaction between $\mathrm{C} 1 \mathrm{q}$ and serine proteases $\mathrm{C} 1 \mathrm{r}$ and $\mathrm{C} 1 \mathrm{~s}$ that initiates the classical complement system pathway [43]. Under physiological conditions, the activity of the subcomponents of $\mathrm{C} 1 \mathrm{r}$ and $\mathrm{C} 1 \mathrm{~s}$ is controlled by the plasma protease $\mathrm{C} 1-\mathrm{INH}$, which has been registered in European markets since 1997 [363, 364]. C1-INH is the first clinical complement inhibitor and inhibits both classical and lectin pathways during the complement cascade [13, 43]. In a variety of experimental ischemic stroke studies, C1-INH treatment reduced brain infarct volume and attenuated neurological deficit during the acute and later stages of stroke $[359,365,366]$. Additional human recombinant $(r h) \mathrm{C} 1$-INH was developed and had a wider effect in reducing ischemic brain injury than plasma-derived C1-INH [367]. The protective effect of C1-INH on stroke outcomes was mainly through inhibiting leukocyte infiltration and myeloperoxidase activity and diminishing neuronal apoptosis [33, 367369]. The detailed information of C1-INH for ischemic stroke therapy is summarized in Table $\mathbf{1 .}$

\subsection{Inhibition of the amplification loop}

\subsubsection{C3 inhibitor: $\mathrm{CVF}$}

C3 is in the central position of the complement cascade and is generated through three pathways of complement activation [370]. $\mathrm{C} 3 \mathrm{~b}$, the active fragment of $\mathrm{C} 3$, plays a key role in forming $\mathrm{C} 3$ convertase and implies the complement response [94]. CVF is a structural homolog of $\mathrm{C} 3 \mathrm{~b} / \mathrm{C} 3 \mathrm{c}$ found in the venom of certain cobra species [371]. It is capable of binding factor B to form stable $\mathrm{C} 3 / \mathrm{C} 5$ convertases that hydrolyze $\mathrm{C} 3$ and $\mathrm{C} 5$ in an uncontrolled manner, causing their depletion [372]. For almost four decades, CVF was used in animal models to explore the role of complement in a variety of disease states, including ischemia/reperfusion injury [373-375]. In experimental ischemic stroke, pretreatment with CVF could inhibit complement activation by removing circulating $\mathrm{C} 3$ and other complement components, exerting beneficial effects on the outcomes of ischemic brain injury [359]. CVF administration 24 hours before surgery resulted in reduced complement activity, combined with enhanced somatosensory-evoked potentials in a rat model of forebrain ischemia [376]. Pretreatment with CVF reduced ischemic brain injury in both adult and neonatal rats [64]. Furthermore, CVF pretreatment also reduced neuronal $\mathrm{C} 3$ deposition in the brain, despite no reduction in microglial C3 deposition and neuronal C9 deposition [63]. However, in a rabbit thromboembolic stroke model, pretreatment with CVF did not affect cerebral blood flow or brain infarct volume within 7 hours of embolization. It is noted that the injection of CVF immediately or 72 hours after cerebral ischemia showed no effect on attenuating brain edema and atrophy after 48 hours of brain injury [377]. These inconsistent results could be due to the distinct administration time of CVF and the difference in the pathophysiological process between adults and neonates (Table 2). Thus, it is possible that CVF served as a therapeutic agent when administered before ischemia. Studies are still warranted to clarify the therapeutic time window and mechanism of CVF in the pathogenesis of ischemic stroke to facilitate clinical transformation.

\subsection{2. $\quad s C R 1$}

An alternative approach to broadly inhibit the amplification loop during complement activation is the recombinant form of endogenous complement $\mathrm{C} 3$ convertase inhibitor, sCR1. It is more effective to inhibit complement activation than other endogenous soluble $\mathrm{C} 3 / \mathrm{C} 5$ convertase inhibitors, such as factor $\mathrm{H}$ and $\mathrm{C} 4-$ binding protein $(\mathrm{C} 4 \mathrm{bp})$ [378]. sCR1 is the soluble extra membranous part of CR1, is shed from leukocytes, and retains full regulatory activity in plasma. It exerted an inhibitory function of spontaneous complement activation via decaying the $\mathrm{C} 3$ and $\mathrm{C} 5$ convertases and was elevated in plasma during the progression of certain diseases [379381]. Numerous studies have shown that the application of sCR1 significantly alleviated complement-mediated tissue damage after ischemia/reperfusion injury [378, 382-386]. In a rat model of myocardial ischemia/reperfusion injury, sCR1 treatment reduced myocardial infarction and leukocyte infiltration within the infarct zone [378]. In a rat model of liver ischemia/reperfusion, intravenous injection of sCR1 24 hours after ischemia reduced complement activity and $\mathrm{C} 3$ deposition on endothelial cells and ameliorated the reperfusion injury [384]. In addition, sCR1 was considered a promising anti-inflammatory therapeutic agent to alleviate complement-mediated ischemic brain injury [387]. In a rat model of cerebral ischemia, intravenous administration of the SCR1-3 or the SCR1518 functional domain of sCR1 1 hour before surgery reduced infarct volume, $\mathrm{C} 3 \mathrm{~b}$ deposition and neutrophil infiltration in the brain and attenuated motor deficits after 24 hours of ischemia [387, 388]. Furthermore, sCR1-sLex (sLex-glycosylated sCR1 modification) treatment showed better neuroprotective effects than unmodified sCR1 treatment in ischemic stroke [24]. However, in a baboon model of ischemic stroke, pretreatment with sCR1 or sCR1-sLex did not affect infarct volume or neurological score, although serum complement activity was 
significantly depressed [389, 390]. These studies suggested that the complement cascade in ischemic stroke was different among species. It is better to use the primate ischemic model to evaluate the therapeutic effect of sCR1 prior to the implementation of large-scale clinical trials.

In addition to the beneficial effects of $\mathrm{SCR} 1$ on models of ischemic diseases, sCR1 also displayed good therapeutic effects on animal models of reverse passive Arthur reaction, complement-mediated experimental glomerulonephritis, acute lung injury, adult respiratory distress syndrome (ARDS), demyelinating experimental allergic encephalitis, allogeneic lung transplantation and arthritis [391-397]. Clinical trials of sCR1 were performed in patients with acute lung injury and respiratory distress syndrome and showed well-tolerated and effectively inhibited complement activation [398]. It will take time to translate the clinical application of sCR1 for the treatment of ischemia stroke. More efforts must be paid in the future to understand the cellular and molecular mechanism of sCR1, which would accelerate the clinical translation of $\mathrm{sCR} 1$ for the treatment of cerebral ischemia.

Table 2. CVF administration for ischemic stroke.

\begin{tabular}{|c|c|c|c|c|c|c|c|}
\hline Animals & Stroke models & $\begin{array}{l}\text { Time of } \\
\text { administration }\end{array}$ & $\begin{array}{l}\text { Routes of } \\
\text { injection }\end{array}$ & $\begin{array}{l}\text { Time point of } \\
\text { observations }\end{array}$ & Outcomes & Mechanisms & Refs \\
\hline $\begin{array}{l}\text { Adult rats \& } \\
\text { 7-day-old rats }\end{array}$ & $\begin{array}{l}1.5 \mathrm{~h} \text { MCAO in adult } \\
\text { rats; } \\
\text { Unilateral carotid } \\
\text { artery ligation } \\
\text { followed by transient } \\
\text { hypoxia in neonates }\end{array}$ & $\begin{array}{l}24 \text { h before } \\
\text { surgery }\end{array}$ & $\begin{array}{l}\text { Intraperitoneal } \\
\text { injection }\end{array}$ & $\begin{array}{l}48 \mathrm{~h} \text { after } \\
\text { surgery }\end{array}$ & $\begin{array}{l}\text { Reduced brain infarct } \\
\text { volume and brain } \\
\text { atrophy }\end{array}$ & Not studied & [64] \\
\hline 7-day-old rats & $\begin{array}{l}\text { Cerebral hypoxic- } \\
\text { ischemic injury }\end{array}$ & $\begin{array}{l}24 \text { h before } \\
\text { surgery }\end{array}$ & $\begin{array}{l}\text { Intraperitoneal } \\
\text { injection }\end{array}$ & $\begin{array}{l}1 \text { day and } 5 \\
\text { days after } \\
\text { cerebral } \\
\text { ischemia }\end{array}$ & $\begin{array}{l}\text { Reduced systemic C3 } \\
\text { and neuronal C3 } \\
\text { deposition in the } \\
\text { brain; Reduced brain } \\
\text { infarct size }\end{array}$ & $\begin{array}{l}\text { Did not affect } \\
\text { neuronal C9 } \\
\text { deposition and } \\
\text { microglial C3 } \\
\text { deposition in } \\
\text { the brain }\end{array}$ & {$[63]$} \\
\hline 7-day-old rats & $\begin{array}{l}\text { Unilateral carotid } \\
\text { artery ligation } \\
\text { followed by transient } \\
\text { hypoxia }\end{array}$ & $\begin{array}{l}24 \text { h before } \\
\text { surgery }\end{array}$ & $\begin{array}{l}\text { Intraperitoneal } \\
\text { injection }\end{array}$ & $\begin{array}{l}24 \text { h after } \\
\text { surgery }\end{array}$ & $\begin{array}{l}\text { Did not reduce infarct } \\
\text { volume }\end{array}$ & Not studied & [300] \\
\hline $\begin{array}{l}\text { Sprague- } \\
\text { Dawley rats }\end{array}$ & $\begin{array}{l}\text { Autologous blood } \\
\text { induced intracerebral } \\
\text { hemorrhage }\end{array}$ & $\begin{array}{l}36 \mathrm{~h}, 24 \mathrm{~h} \text {, and } \\
12 \mathrm{~h} \text { before } \\
\text { induction of } \\
\text { intracerebral } \\
\text { hemorrhage }\end{array}$ & $\begin{array}{l}\text { Intraperitoneal } \\
\text { injection }\end{array}$ & $\begin{array}{l}2 \mathrm{~h}, 24 \mathrm{~h} \text {, or } 72 \\
\mathrm{~h} \text { after } \\
\text { intracerebral } \\
\text { hemorrhage }\end{array}$ & $\begin{array}{l}\text { Reduced brain water } \\
\text { content and MPO } \\
\text { activity at } 72 \text { hours } \\
\text { after intracerebral } \\
\text { hemorrhage }\end{array}$ & Not studied & [430] \\
\hline $\begin{array}{l}\text { 21-day-old } \\
\text { rats }\end{array}$ & $\begin{array}{l}\text { Right common } \\
\text { carotid artery ligation } \\
\text { and hypoxia }\end{array}$ & $\begin{array}{l}24 \mathrm{~h} \\
\text { immediately } \\
\text { before and } 72 \mathrm{~h} \\
\text { after surgery }\end{array}$ & $\begin{array}{l}\text { Intraperitoneal } \\
\text { injection }\end{array}$ & $\begin{array}{l}24 \mathrm{~h}, 48 \mathrm{~h} \text { after } \\
\text { cerebral } \\
\text { ischemia }\end{array}$ & $\begin{array}{l}\text { Did not did not reduce } \\
\text { the neuronal loss, } \\
\text { brain edema or } \\
\text { atrophy }\end{array}$ & Not studied & [377] \\
\hline $\begin{array}{l}\text { New Zealand } \\
\text { white rabbits }\end{array}$ & $\begin{array}{l}\text { Thromboembolic } \\
\text { stroke }\end{array}$ & $\begin{array}{l}48 \text { h before } \\
\text { surgery }\end{array}$ & $\begin{array}{l}\text { Intraperitoneal } \\
\text { injection }\end{array}$ & $\begin{array}{l}7 \text { h after } \\
\text { surgery }\end{array}$ & $\begin{array}{l}\text { Did not reduce brain } \\
\text { infarct volume }\end{array}$ & Not studied & [431] \\
\hline $\begin{array}{l}\text { Sprague- } \\
\text { Dawley rats }\end{array}$ & $\begin{array}{l}\text { Reversible } \\
\text { incomplete forebrain } \\
\text { ischemia }\end{array}$ & $\begin{array}{l}24 \mathrm{~h} \text { before } \\
\text { surgery }\end{array}$ & $\begin{array}{l}\text { Intraperitoneal } \\
\text { injection }\end{array}$ & $\begin{array}{l}\text { Within } 4 \mathrm{~h} \\
\text { after cerebral } \\
\text { ischemia }\end{array}$ & $\begin{array}{l}\text { Had a tendency to } \\
\text { increase focal cerebral } \\
\text { blood flow and } \\
\text { increased } \\
\text { somatosensory evoked } \\
\text { potentials in the } \\
\text { cortex }\end{array}$ & Not studied & [376] \\
\hline
\end{tabular}

\subsubsection{IVIg (Table 3)}

IVIg is a purified concentrated human immunoglobulin solution composed primarily of IgG extracted from the plasma of thousands of healthy donors [12, 399]. It was FDA approved and clinically used as a first-line therapeutic modality for diverse autoimmune and several inflammatory diseases [12]. Recently, experimental studies have shown that IVIg has a beneficial therapeutic potential in acute brain injury, including trauma, subarachnoid hemorrhage, and ischemic stroke [12]. As a scavenger of activated complement fragments, IVIg could inhibit complement activation and attenuate brain damage in a rodent stroke model [269]. In a mouse model of 1hour MCAO, IVIg injection via the femoral vein 0.5 hour before or 1 hour after the surgery reduced brain infarct area, mortality, and neurological deficit score at 72 hours after ischemia. In addition, IVIg also inhibited $\mathrm{C} 3 \mathrm{~b}$ deposition and TLR2 expression in the brain [400]. IVIg reduced neuronal apoptosis induced by OGD via inhibiting the upregulation of $\mathrm{C} 3$ and activation of caspase-3 [269]. These studies suggested that IVIg was 
neuroprotective by modulating complement activation during ischemic conditions. The anti-inflammatory effect of IVIg was reducing TLR expression, suppressing high mobility group box 1 (HMGB1)-mediated TLR activation, and reducing the levels of the inflammatory components NLRP1 and NLRP3 [401, 402]. In vitro studies showed that IVIg protected neurons and endothelial dysfunction by inhibiting p38MAPK, c-Jun NH2-terminal kinase, p65 phosphorylation, and dampening the decline in the anti-apoptotic proteins $\mathrm{Bcl}$ 2 and Bcl-XL induced by OGD [401, 403, 404]. Apart from the described pathways, multiple conceivable mechanisms were involved in how IVIg facilitated protection in ischemic stroke [12]. For example, IVIg could induce a regulatory phenotype in macrophages in an Fc-fragment manner and target the inhibitory receptor Fc $\gamma$ RIIB, subsequently suppressing $\mathrm{T}$ cell-mediated immune responses during ischemic stroke. Therefore, IVIg is a promising therapeutic for ischemic stroke. Because IVIg treatment was mostly used in the experimental studies, it should be studied in clinical stroke patients in the future.

Table 3. IVIg treatment for ischemic stroke.

\begin{tabular}{|c|c|c|c|c|c|c|c|}
\hline Animals & $\begin{array}{l}\text { Stroke } \\
\text { models }\end{array}$ & $\begin{array}{l}\text { Time of } \\
\text { administration }\end{array}$ & $\begin{array}{l}\text { Routes } \\
\text { injection }\end{array}$ & $\begin{array}{l}\text { Time point } \\
\text { of } \\
\text { observations } \\
\end{array}$ & Outcomes & Mechanisms & Refs \\
\hline $\begin{array}{l}\text { C57BL/6 } \\
\text { mice }\end{array}$ & $\mathrm{MCAO}^{\mathrm{h}}$ & $\begin{array}{l}0.5 \mathrm{~h} \text { before or } \\
1 \mathrm{~h}, 3 \mathrm{~h} \text { and } 6 \mathrm{~h} \\
\text { after surgery }\end{array}$ & $\begin{array}{l}\text { Intravenous } \\
\text { injection of } \\
\text { IVIg }(1 \mathrm{~g} / \mathrm{kg})\end{array}$ & $\begin{array}{l}72 \mathrm{~h} \text { after } \\
\text { MCAO }\end{array}$ & $\begin{array}{l}\text { Reduced brain infarct } \\
\text { area, mortality, and } \\
\text { neurological deficit score }\end{array}$ & $\begin{array}{l}\text { Inhibited } \mathrm{C} 3 \mathrm{~b} \text { deposition } \\
\text { and TLR2 expression in the } \\
\text { brain }\end{array}$ & {$[400]$} \\
\hline $\begin{array}{l}\mathrm{C} 57 \mathrm{BL} / 6 \mathrm{~J} \\
\text { mice }\end{array}$ & $\mathrm{MCAO}^{\mathrm{h}}$ & $\begin{array}{lr}3 & \text { h } \\
\text { surgery } & \text { after }\end{array}$ & $\begin{array}{l}\text { Intravenous } \\
\text { injection of } \\
\text { IVIg }(1 \mathrm{~g} / \mathrm{kg})\end{array}$ & $\begin{array}{l}6 \mathrm{~h}, 24 \mathrm{~h} \text { after } \\
\text { MCAO }\end{array}$ & $\begin{array}{l}\text { Increased low-density } \\
\text { lipoprotein receptor- } \\
\text { related protein } 1 \text { (LRP1) } \\
\text { tyrosine phosphorylation } \\
\text { in the brain }\end{array}$ & 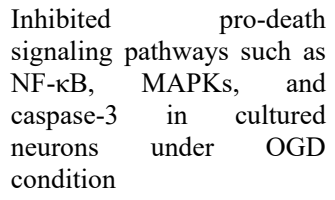 & [432] \\
\hline $\begin{array}{l}\text { Sprague- } \\
\text { Dawley rats }\end{array}$ & $\begin{array}{l}2 \mathrm{~h} \\
\mathrm{MCAO}\end{array}$ & $\begin{array}{l}\text { Just after } \\
\text { surgery }\end{array}$ & $\begin{array}{l}\text { Intravenous } \\
\text { injection } \\
\text { IVIg } \\
\mathrm{mg} / \mathrm{kg})\end{array}$ & $\begin{array}{l}72 \mathrm{~h} \text { after } \\
\text { MCAO }\end{array}$ & $\begin{array}{l}\text { Reduced neurological } \\
\text { deficit score }\end{array}$ & Not studied & [433] \\
\hline $\begin{array}{l}\mathrm{C} 57 \mathrm{BL} / 6 \\
\text { mice }\end{array}$ & $\mathrm{MCAO}^{\mathrm{h}}$ & $\begin{array}{ll}3 & \text { h } \\
\text { surgery } & \text { after }\end{array}$ & $\begin{array}{l}\text { Intravenous } \\
\text { injection of } \\
\text { IVIg }(1 \mathrm{~g} / \mathrm{kg})\end{array}$ & $\begin{array}{l}6 \mathrm{~h}, 24 \mathrm{~h} \text { after } \\
\text { MCAO }\end{array}$ & $\begin{array}{l}\text { Reduced TL2, TLR } 4 \text { and } \\
\text { TLR8 expression in the } \\
\text { brain; Reduced NF- } \mathrm{B} \\
\text { and MAPK activities in } \\
\text { the brain }\end{array}$ & $\begin{array}{l}\text { Inhibited HMGB1 induced } \\
\text { activation of NF- } \mathrm{B}-\mathrm{p}-\mathrm{p} 65 \text {, } \\
\text { p-JNK, p38 MAPK and p-c- } \\
\text { Jun, and increased Bcl-2 } \\
\text { expression in cultured } \\
\text { neurons under oxygen and } \\
\text { glucose deprivation }\end{array}$ & [403] \\
\hline $\begin{array}{l}\mathrm{C} 57 \mathrm{BL} / 6 \\
\text { mice }\end{array}$ & $\begin{array}{l}1 \\
\mathrm{MCAO}\end{array}$ & $\begin{array}{l}3 \quad \text { h after } \\
\text { surgery }\end{array}$ & $\begin{array}{l}\text { Intravenous } \\
\text { injection of } \\
\text { IVIg }(2 \mathrm{~g} / \mathrm{kg})\end{array}$ & $\begin{array}{l}24 \mathrm{~h} \text { after } \\
\mathrm{MCAO}\end{array}$ & $\begin{array}{l}\text { Reduced } \mathrm{CD}^{+} 5^{+} \\
\text {leukocyte infiltration in } \\
\text { the brain }\end{array}$ & Not studied & [401] \\
\hline $\begin{array}{l}\mathrm{C} 57 \mathrm{BL} / 6 \mathrm{~J} \\
\text { mice }\end{array}$ & $\mathrm{MCAO}^{\mathrm{h}}$ & 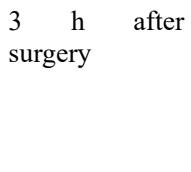 & $\begin{array}{l}\text { Intravenous } \\
\text { injection of } \\
\text { IVIg }(1 \mathrm{~g} / \mathrm{kg})\end{array}$ & $\begin{array}{l}6 \mathrm{~h}, 24 \mathrm{~h}, 72 \\
\mathrm{~h} \\
\text { MCAO }\end{array}$ & $\begin{array}{l}\text { Reduced inflammasome } \\
\text { components NLRP1 and } \\
\text { NLRP3, and IL-1 } \beta \text { and } \\
\text { IL-18 expression in the } \\
\text { brain }\end{array}$ & Not studied & [402] \\
\hline $\begin{array}{l}\mathrm{C} 57 \mathrm{BL} / 6 \\
\text { mice }\end{array}$ & $\mathrm{MCAO}^{\mathrm{h}}$ & $\begin{array}{l}0.5 \text { h before or } \\
3 \quad \text { h after } \\
\text { surgery }\end{array}$ & $\begin{array}{l}\text { Intravenous } \\
\text { injection of } \\
\text { IVIg }(2 \mathrm{~g} / \mathrm{kg})\end{array}$ & $\begin{array}{l}24 \mathrm{~h} \text { after } \\
\text { MCAO }\end{array}$ & $\begin{array}{l}\text { Reduced brain infarct } \\
\text { volume and neurological } \\
\text { deficit, increased } \\
\text { neuronal survival }\end{array}$ & $\begin{array}{l}\text { Inhibited phosphorylation of } \\
\text { the cell death-associated } \\
\text { kinases p38 MAPK, JNK } \\
\text { and p65 in cultured neurons } \\
\text { under OGD condition }\end{array}$ & [404] \\
\hline Wistar rats & $\begin{array}{l}1.5 \mathrm{~h} \\
\mathrm{MCAO}\end{array}$ & $\begin{array}{l}0.5 \mathrm{~h} \text { before } \\
\text { surgery }\end{array}$ & $\begin{array}{l}\text { Intravenous } \\
\text { injection of } \\
\text { IVIg }(1 \mathrm{~g} / \mathrm{kg})\end{array}$ & $\begin{array}{l}24 \mathrm{~h} \text { after } \\
\mathrm{MCAO}\end{array}$ & $\begin{array}{l}\text { Reduced brain infarct } \\
\text { volume and neurological } \\
\text { deficit score }\end{array}$ & Not studied & [434] \\
\hline $\begin{array}{l}\mathrm{C} 57 \mathrm{BL} / 6 \\
\text { mice }\end{array}$ & $\mathrm{MCAO}^{\mathrm{h}}$ & $\begin{array}{l}0.5 \text { h before or } \\
3 \quad \text { h after } \\
\text { surgery }\end{array}$ & $\begin{array}{l}\text { Intravenous } \\
\text { injection of } \\
\text { IVIg }(2 \mathrm{~g} / \mathrm{kg})\end{array}$ & $\begin{array}{l}24 \mathrm{~h} \text { after } \\
\mathrm{MCAO}\end{array}$ & $\begin{array}{l}\text { Reduced brain infarct } \\
\text { volume and neurological } \\
\text { deficit }\end{array}$ & $\begin{array}{l}\text { Inhibited C3 elevation in the } \\
\text { brain; Reduced endothelial } \\
\text { cell adhesion, lymphocyte } \\
\text { infiltration, and microglial } \\
\text { activation }\end{array}$ & [269] \\
\hline
\end{tabular}


Table 4. sCR1 treatment for ischemic stroke.

\begin{tabular}{|c|c|c|c|c|c|c|c|}
\hline Animals & Stroke models & $\begin{array}{l}\text { Time of } \\
\text { administration }\end{array}$ & $\begin{array}{l}\text { Routes } \\
\text { injection }\end{array}$ & $\begin{array}{l}\text { Time point of } \\
\text { observations }\end{array}$ & Outcomes & Mechanisms & Refs \\
\hline $\begin{array}{l}\text { Sprague- } \\
\text { Dawley } \\
\text { rats }\end{array}$ & $1 \mathrm{~h} \mathrm{MCAO}$ & $\begin{array}{lcl}1 & h & \text { before } \\
\text { surgery } & \end{array}$ & $\begin{array}{l}\text { Intravenous } \\
\text { injection of sCR1 }\end{array}$ & $\begin{array}{l}1 \mathrm{~h}, 24 \mathrm{~h} \text { after } \\
\text { surgery }\end{array}$ & $\begin{array}{l}\text { Reduced brain } \\
\text { infarct volume } \\
\text { and } \\
\text { neurological } \\
\text { motor deficits }\end{array}$ & $\begin{array}{l}\text { Reduced neutrophil } \\
\text { accumulation and } \\
\text { inflammation; } \\
\text { Reduced } \mathrm{C} 4 \mathrm{~b} \\
\text { deposition in the } \\
\text { cortex }\end{array}$ & [387] \\
\hline $\begin{array}{l}\text { Sprague- } \\
\text { Dawley } \\
\text { rats }\end{array}$ & $2 \mathrm{~h} \mathrm{MCAO}$ & $\begin{array}{l}1 \quad h \quad \text { before } \\
\text { surgery }\end{array}$ & $\begin{array}{l}\text { Intravenous } \\
\text { injection of sCR } 1\end{array}$ & $\begin{array}{l}2 \mathrm{~h}, 24 \mathrm{~h} \text { after } \\
\text { surgery }\end{array}$ & $\begin{array}{l}\text { Reduced brain } \\
\text { infarct size and } \\
\text { neurological } \\
\text { deficit scores }\end{array}$ & $\begin{array}{l}\text { Inhibited neutrophil } \\
\text { infiltration and } \mathrm{C} 3 \mathrm{~b} \\
\text { deposition in the } \\
\text { brain }\end{array}$ & [388] \\
\hline $\begin{array}{l}\text { Adult male } \\
\text { baboons }\end{array}$ & $1.25 \mathrm{~h} \mathrm{MCAO}$ & $\begin{array}{l}45 \text { min before } \\
\text { surgery }\end{array}$ & $\begin{array}{l}\text { Intravenous } \\
\text { injection of sCR } 1\end{array}$ & $\begin{array}{l}72 \mathrm{~h} \text { and } 10 \\
\text { days of post- } \\
\text { surgery }\end{array}$ & $\begin{array}{l}\text { Did not affect } \\
\text { brain infarct } \\
\text { volume and } \\
\text { neurological } \\
\text { scores }\end{array}$ & Not studied & [389] \\
\hline $\begin{array}{l}7 \text {-day-old } \\
\text { rats }\end{array}$ & $\begin{array}{l}\text { Unilateral } \\
\text { carotid artery } \\
\text { ligation } \\
\text { followed by } \\
\text { transient } \\
\text { hypoxia }\end{array}$ & $\begin{array}{l}24 \quad \mathrm{~h} \text { before } \\
\text { surgery }\end{array}$ & $\begin{array}{l}\text { Intraperitoneal } \\
\text { injection of sCR1 } \\
\text { or sCR1-sLex }\end{array}$ & $\begin{array}{l}24 \quad \mathrm{~h} \text { after } \\
\text { surgery }\end{array}$ & $\begin{array}{l}\text { Did not reduce } \\
\text { infarct volume }\end{array}$ & Not studied & [300] \\
\hline Mice & 0.75 h MCAO & $\begin{array}{l}\text { Immediately } \\
\text { before MCAO }\end{array}$ & $\begin{array}{l}\text { Administration of } \\
\text { sCR1 or sCR1- } \\
\text { sLex }\end{array}$ & $\begin{array}{l}24 \text { h after } \\
\text { stroke }\end{array}$ & $\begin{array}{l}\text { Reduced brain } \\
\text { infarct volume } \\
\text { and } \\
\text { neurological } \\
\text { deficit score }\end{array}$ & $\begin{array}{l}\text { Inhibited neutrophil } \\
\text { and platelet } \\
\text { accumulation in the } \\
\text { brain }\end{array}$ & {$[24]$} \\
\hline
\end{tabular}

\subsection{Inhibition of effector function (Table 4)}

\subsubsection{The C3aR antagonist}

$\mathrm{C} 3 \mathrm{aR}$ is the receptor of $\mathrm{C} 3 \mathrm{a}$, which is generated from $\mathrm{C} 3$ after being cleaved by $\mathrm{C} 3$ convertase. As one of the terminal mediators of the complement system, genetic depletion or a specific antagonist of $\mathrm{C} 3 \mathrm{aR}$ was used to define the role of $\mathrm{C} 3 \mathrm{aR}$ and modulate its activity during different kinds of diseases, including intestinal ischemia/reperfusion injury, myocardial ischemia and reperfusion injury, hypertension, brain death induced by lung injury, kidney disease, type 2 diabetic nephropathy, arthritis, $\mathrm{AD}$, intracerebral hemorrhage, and ischemic stroke [34, 67, 172, 174, 339, 405-413]. Studies have demonstrated that $\mathrm{C} 3 \mathrm{aR}$ antagonists emolliate ischemic brain injury, mainly through reducing neutrophil infiltration and the inflammatory response at the acute stage of ischemic stroke [34, 174]. However, it is still under debate whether $\mathrm{C} 3 \mathrm{aR}$ antagonists are beneficial or detrimental for the promotion of neurogenesis after ischemic stroke. In a transient ischemic stroke study, a low dose of C3aR antagonist $(1 \mathrm{mg} / \mathrm{kg})$ within 3 days after ischemia increased $\mathrm{DCX}^{+}$neuroblast proliferation in the subventricular zone at 7 days post-ischemia, while a high dose of C3aR antagonist $(40 \mathrm{mg} / \mathrm{kg}$ ) suppressed neural progenitor cell proliferation [414]. The opposite results were observed in a mouse permanent ischemia model. $\mathrm{C} 3 \mathrm{aR}$ antagonist injection twice daily for 10 days after surgery inhibited neuroblast proliferation in the subgranular zone (SGZ) of the hippocampus and in the dentate gyrus granule cell layer (GCL) at 7 to 21 days of post-ischemia [67]. The discrepancy of these studies could be the result of the distinct pathological response of 
the whether stroke was blood-perfused and the different doses and regimens of the $\mathrm{C} 3 \mathrm{aR}$ antagonist injection [415]. To better optimize the therapeutic strategies modulating $\mathrm{C} 3 \mathrm{aR}$ activity during the pathological process of cerebral ischemia, different doses, injection routes, and injection time-points should be explored in the future in different models of ischemic stroke.

\subsubsection{Anti-C5 monoclonal antibodies and the C5aR1 antagonist}

C5a is the active fragment of C5 and exerts its pathophysiological functions via binding with its receptor C5aR. As another key downstream effector of the complement system, the interaction between C5a and C5aR1 was widely recognized as a pro-inflammatory signaling in multiple diseases [335]. Both anti-C5 monoclonal antibodies and C5aR1 antagonists were developed and used as therapeutic agents to attenuate tissue injury in various rodent disease models, including kidney ischemia/reperfusion injury, intestine ischemia/reperfusion injury, sepsis, spinal cord injury, CNS lupus, hypertension, AD, intracerebral hemorrhage, and ischemic stroke [270, 339, 340, 416-423]. In a rat model of ischemic stroke, administration of the anti-C5 monoclonal antibody, specifically blocking the generation of $\mathrm{C} 5 \mathrm{a}$ and $\mathrm{C} 5 \mathrm{~b}-9$, reduced brain infarct volume and edema and improved neurological function at 24 hours after ischemia [270, 424]. Similarly, pre- or posttreatment with the C5aR1 antagonist AcF [OpdChaWR], also known as PMX53, reduced cerebral infarct volume at 24 hours of ischemic stroke in mice [425]. These studies suggested that the modulation of $\mathrm{C} 5 \mathrm{a} / \mathrm{C} 5 \mathrm{aR}$ signaling was a beneficial potential at the early stage of ischemic stroke. However, the effect of anti-C5 monoclonal antibodies and $\mathrm{C} 5 \mathrm{aR} 1$ antagonists in ischemic stroke is limited. Whether they still exert protective roles at the later stage of ischemic stroke and what mechanism they work through are both poorly investigated. Therefore, developing better strategies for modulating $\mathrm{C} 5 \mathrm{a} / \mathrm{C} 5 \mathrm{aR}$ activities in ischemic stroke before the application of potential candidates to clinical practice is greatly needed.

\section{Challenges and prospective}

\subsection{Evolving challenges}

Although the value of inhibiting complement in a therapeutic context of ischemic stroke in experimental studies has long been recognized, bringing complementtargeted drugs into clinical use has proved challenging. While a broad variety of candidate drugs that target various stages of the complement cascade are currently being evaluated in clinical trials, they cannot be applied to all complement-driven diseases [43]. The available therapeutics modulating the complement system for stroke patients are still limited [426]. Therefore, challenges remain and must be overcome before the translation of complement-targeted therapeutics for the treatment of clinical ischemic stroke is achieved. It is important to avoid infectious complications and preserve the physiological and regenerative functions of different components during the pathogenesis of ischemic stroke when using systemically active complement-blocking agents. First, as several components, such as C1q, C3, and $\mathrm{C} 3 \mathrm{aR}$, are involved in synaptic plasticity and neurogenesis under both normal and stroke conditions, it is imperative to choose more specific and focused complement modulation, which may cause fewer undesired complications $[359,427]$. The timing, dose, and duration of treatment (transient or chronic) also require careful consideration since they are all likely factors affecting the efficiency of therapeutic strategies. Second, the use of traditional small molecules or biologic approaches to modulate the complement system is imperative. The majority of emerging complement therapeutics commercially available are antibodies or proteins, which are too large to cross the intact BBB [359]. Although they may prove effective in acute brain injury such as ischemic stroke where the BBB is disrupted, their pharmacologic effects are compromised and decline at the chronic phase of ischemic stroke or during chronic cerebral ischemia. In addition, choosing therapeutic agents whose circulating levels are very high and whose turnover rates are relatively rapid is required to sustain benefits for patients with chronic cerebral ischemia [427]. A third challenge is linking the discoveries of the changes in complement components and effector mechanisms causing tissue injury in both experimental and clinical ischemic stroke. The determination of the consistency between basic research and clinical studies is the foundation of applying therapeutics targeting complement systems into clinical use. Last but not least, it is important to choose the right therapy that is the most appropriate for each individual patient if complement-targeted therapeutics are to be successful in clinical trials. As a biomarker, complement activation in plasma could inform the appropriate selection of treatment for individual patients and help identify optimal therapeutics.

\subsection{Future Perspective}

It is undeniable that the complement system is implicated in the pathophysiology of ischemic stroke. However, our understanding and insight into the cascade mechanisms and their complex interaction with neuronal cells in the brain after ischemic stroke is still in its nascent phase. 
Currently, the predominant focus of studies on complement and ischemic stroke is on the role of complement in eliciting the inflammatory cascade and contributing to tissue injury. The majority of studies mainly investigated acute-phase outcomes, where complement depletion or inhibition prevented the activation of pro-inflammatory mechanisms and the deficit of neurological functions. By contrast, few studies have explored the role of the complement system in subacute and chronic phases after ischemic stroke, when complement components could be important for regeneration and remodeling. An investigation of the temporal and spatial changes, as well as the role of different complement components at subacute and chronic stages after stroke, is useful for guiding therapeutic strategies targeting the complement system and reducing side effects. Therefore, future studies should design experimental models and evaluate outcomes for longer endpoints after stroke. Although the essential role of complement in synaptic pruning, loss, and remodeling during CNS development and neurodegenerative conditions has been demonstrated, it is unclear whether complement is also necessary in synaptic loss or remodeling in the early and delayed pathophysiological processes of ischemic stroke [206, 207, 213]. In addition, whether serum-derived complement and resident cells in brain-derived complement have the same or distinct impacts on ischemic stroke outcomes remains ambiguous. Addressing these unanswered questions could reveal a more diverse role for complement in ischemic brain injury and rescue.

In summary, numerous preclinical studies have demonstrated that the complement system acts as an important player involved in tissue injury and recovery. Consequently, a wealth of complement-targeted therapeutics has been developed to modulate complement activation and attenuate tissue injury. Much effort is still needed to elucidate the precise role of different complement components in the pathophysiological process of ischemic stroke. In the next decades, there will be dramatic improvements in developing novel therapeutic candidates with potentially good safety profiles for the treatment of ischemic stroke.

\section{Acknowledgements}

The study was supported by the National Natural Science Foundation of China (81771251, GYY; 81771244, ZJZ; 81471178, GYY; 81522015, YTW), National Key Research and Development Program of China (2016YFC1300600), the K. C. Wong Education Foundation (GYY), and the Science and Technology Commission of Shanghai Municipality (17ZR1413600, ZJZ).

\section{Disclosure statement}

The authors declared no conflicts of interest.

\section{References}

[1] Feigin VL, Krishnamurthi RV, Parmar P, Norrving B, Mensah GA, Bennett DA, et al. (2015). Update on the Global Burden of Ischemic and Hemorrhagic Stroke in 1990-2013: The GBD 2013 Study. Neuroepidemiology, 45:161-176.

[2] Ng M, Fleming T, Robinson M, Thomson B, Graetz N, Margono C, et al. (2014). Global, regional, and national prevalence of overweight and obesity in children and adults during 1980-2013: a systematic analysis for the Global Burden of Disease Study 2013. Lancet, 384:766-781.

[3] Hankey GJ (2017). Stroke. Lancet, 389:641-654.

[4] Wang W, Jiang B, Sun H, Ru X, Sun D, Wang L, et al. (2017). Prevalence, Incidence, and Mortality of Stroke in China: Results from a Nationwide PopulationBased Survey of 480687 Adults. Circulation, 135:759-771.

[5] Alawieh A, Elvington A, Zhu H, Yu J, Kindy MS, Atkinson C, et al. (2015). Modulation of post-stroke degenerative and regenerative processes and subacute protection by site-targeted inhibition of the alternative pathway of complement. J Neuroinflammation, 12:247.

[6] Komotar RJ, Kim GH, Otten ML, Hassid B, Mocco J, Sughrue ME, et al. (2008). The role of complement in stroke therapy. Adv Exp Med Biol, 632:23-33.

[7] Komotar RJ, Starke RM, Arias EJ, Garrett MC, Otten ML, Merkow MB, et al. (2009). The complement cascade: new avenues in stroke therapy. Curr Vasc Pharmacol, 7:287-292.

[8] Lindsberg PJ, Ohman J, Lehto T, KarjalainenLindsberg ML, Paetau A, Wuorimaa T, et al. (1996). Complement activation in the central nervous system following blood-brain barrier damage in man. Ann Neurol, 40:587-596.

[9] Pedersen ED, Loberg EM, Vege E, Daha MR, Maehlen J, Mollnes TE (2009). In situ deposition of complement in human acute brain ischaemia. Scand $\mathbf{J}$ Immunol, 69:555-562.

[10] Arumugam TV, Woodruff TM, Lathia JD, Selvaraj PK, Mattson MP, Taylor SM (2009). Neuroprotection in stroke by complement inhibition and immunoglobulin therapy. Neuroscience, 158:1074-1089.

[11] Qu H, Ricklin D, Lambris JD (2009). Recent developments in low molecular weight complement inhibitors. Mol Immunol, 47:185-195.

[12] Thom V, Arumugam TV, Magnus T, Gelderblom M (2017). Therapeutic Potential of Intravenous Immunoglobulin in Acute Brain Injury. Front Immunol, 8:875.

[13] Alawieh A, Elvington A, Tomlinson S (2015). Complement in the Homeostatic and Ischemic Brain. Front Immunol, 6:417. 
[14] Petrovic-Djergovic D, Goonewardena SN, Pinsky DJ (2016). Inflammatory Disequilibrium in Stroke. Circ Res, 119:142-158.

[15] Walport MJ (2001). Complement. First of two parts. N Engl J Med, 344:1058-1066.

[16] Walport MJ (2001). Complement. Second of two parts. N Engl J Med, 344:1140-1144.

[17] Giang J, Seelen MAJ, van Doorn MBA, Rissmann R, Prens EP, Damman J (2018). Complement Activation in Inflammatory Skin Diseases. Front Immunol, 9:639.

[18] Ricklin D, Hajishengallis G, Yang K, Lambris JD (2010). Complement: a key system for immune surveillance and homeostasis. Nat Immunol, 11:785797.

[19] Gorsuch WB, Chrysanthou E, Schwaeble WJ, Stahl GL (2012). The complement system in ischemiareperfusion injuries. Immunobiology, 217:1026-1033.

[20] Ziccardi RJ, Tschopp J (1982). The dissociation properties of native $\mathrm{C} 1$. Biochem Biophys Res Commun, 107:618-623.

[21] Nayak A, Pednekar L, Reid KB, Kishore U (2012). Complement and non-complement activating functions of $\mathrm{Clq}$ : a prototypical innate immune molecule. Innate Immun, 18:350-363.

[22] Dietzschold B, Schwaeble W, Schafer MK, Hooper DC, Zehng YM, Petry F, et al. (1995). Expression of C1q, a subcomponent of the rat complement system, is dramatically enhanced in brains of rats with either Borna disease or experimental allergic encephalomyelitis. J Neurol Sci, 130:11-16.

[23] Goldsmith SK, Wals P, Rozovsky I, Morgan TE, Finch CE (1997). Kainic acid and decorticating lesions stimulate the synthesis of $\mathrm{C} 1 \mathrm{q}$ protein in adult rat brain. J Neurochem, 68:2046-2052.

[24] Huang J, Kim LJ, Mealey R, Marsh HC, Jr., Zhang Y, Tenner AJ, et al. (1999). Neuronal protection in stroke by an sLex-glycosylated complement inhibitory protein. Science, 285:595-599.

[25] Stevens B, Allen NJ, Vazquez LE, Howell GR, Christopherson KS, Nouri N, et al. (2007). The classical complement cascade mediates CNS synapse elimination. Cell, 131:1164-1178.

[26] Chu Y, Jin X, Parada I, Pesic A, Stevens B, Barres B, et al. (2010). Enhanced synaptic connectivity and epilepsy in C1q knockout mice. Proc Natl Acad Sci U S A, 107:7975-7980.

[27] Bialas AR, Stevens B (2013). TGF-beta signaling regulates neuronal $\mathrm{C} 1 \mathrm{q}$ expression and developmental synaptic refinement. Nat Neurosci, 16:1773-1782.

[28] Fonseca MI, Chu SH, Hernandez MX, Fang MJ, Modarresi L, Selvan P, et al. (2017). Cell-specific deletion of C1qa identifies microglia as the dominant source of $\mathrm{Clq}$ in mouse brain. J Neuroinflammation, $14: 48$.

[29] Fraser DA, Pisalyaput K, Tenner AJ (2010). C1q enhances microglial clearance of apoptotic neurons and neuronal blebs, and modulates subsequent inflammatory cytokine production. J Neurochem, 112:733-743.

[30] Lai W, Xie X, Zhang X, Wang Y, Chu K, Brown J, et al. (2018). Inhibition of Complement Drives Increase in Early Growth Response Proteins and Neuroprotection Mediated by Salidroside After Cerebral Ischemia. 41:449-463.

[31] Ten VS, Sosunov SA, Mazer SP, Stark RI, Caspersen $\mathrm{C}$, Sughrue ME, et al. (2005). C1q-deficiency is neuroprotective against hypoxic-ischemic brain injury in neonatal mice. Stroke, 36:2244-2250.

[32] Ten VS, Yao J, Ratner V, Sosunov S, Fraser DA, Botto M, et al. (2010). Complement component clq mediates mitochondria-driven oxidative stress in neonatal hypoxic-ischemic brain injury. J Neurosci, 30:2077-2087.

[33] De Simoni MG, Rossi E, Storini C, Pizzimenti S, Echart C, Bergamaschini L (2004). The powerful neuroprotective action of $\mathrm{C} 1$-inhibitor on brain ischemia-reperfusion injury does not require $\mathrm{C} 1 \mathrm{q}$. Am J Pathol, 164:1857-1863.

[34] Mocco J WJM, Andrew F. Ducruet, Sergei A. Sosunov, Michael E. Sughrue, Benjamin G. Hassid, M. Nathan Nair, Ilya Laufer, Ricardo J. Komotar, M. Claire, H. Holland, David J. Pinsky, E. Sander Connolly ( 2006;). Complement Component C3 Mediates Inflammatory Injury Following Focal Cerebral Ischemia. Circulation Research, 99:209-217.

[35] Ruseva MM, Heurich M (2014). Purification and characterization of human and mouse complement $\mathrm{C} 3$. Methods Mol Biol, 1100:75-91.

[36] de Bruijn MH, Fey GH (1985). Human complement component $\mathrm{C} 3$ : cDNA coding sequence and derived primary structure. Proc Natl Acad Sci U S A, 82:708712.

[37] Lundwall A, Wetsel RA, Domdey H, Tack BF, Fey GH (1984). Structure of murine complement component C3. I. Nucleotide sequence of cloned complementary and genomic DNA coding for the beta chain. J Biol Chem, 259:13851-13856.

[38] Wetsel RA, Lundwall A, Davidson F, Gibson T, Tack BF, Fey GH (1984). Structure of murine complement component C3. II. Nucleotide sequence of cloned complementary DNA coding for the alpha chain. J Biol Chem, 259:13857-13862.

[39] Wetsel RA (1995). Structure, function and cellular expression of complement anaphylatoxin receptors. Curr Opin Immunol, 7:48-53.

[40] Nonaka M, Natsuume-Sakai S, Kaidoh T, Nonaka M, Takahashi M (1980). Characterization of allotypic determinants of murine complement C3. J Immunol, 125:2025-2030.

[41] Fearon DT (1980). Identification of the membrane glycoprotein that is the $\mathrm{C} 3 \mathrm{~b}$ receptor of the human erythrocyte, polymorphonuclear leukocyte, B lymphocyte, and monocyte. J Exp Med, 152:20-30.

[42] van Lookeren Campagne M, Wiesmann C, Brown EJ (2007). Macrophage complement receptors and pathogen clearance. Cell Microbiol, 9:2095-2102.

[43] Ricklin D, Mastellos DC, Reis ES, Lambris JD (2018). The renaissance of complement therapeutics. Nat Rev Nephrol, 14:26-47.

[44] Daha MR (2010). Role of complement in innate 
immunity and infections. Crit Rev Immunol, 30:47-52.

[45] Helmy KY, Katschke KJ, Jr., Gorgani NN, Kljavin NM, Elliott JM, Diehl L, et al. (2006). CRIg: a macrophage complement receptor required for phagocytosis of circulating pathogens. Cell, 124:915927.

[46] Tamam Y, Iltumur K, Apak I (2005). Assessment of acute phase proteins in acute ischemic stroke. Tohoku J Exp Med, 206:91-98.

[47] Cojocaru IM, Cojocaru M, Tanasescu R, Burcin C, Atanasiu AN, Petrescu AM, et al. (2008). Changes in plasma levels of complement in patients with acute ischemic stroke. Rom J Intern Med, 46:77-80.

[48] Mocco J, Wilson DA, Komotar RJ, Sughrue ME, Coates K, Sacco RL, et al. (2006). Alterations in plasma complement levels after human ischemic stroke. Neurosurgery, 59:28-33; discussion 28-33.

[49] Stokowska A, Olsson S, Holmegaard L, Jood K, Blomstrand C, Jern C, et al. (2013). Cardioembolic and small vessel disease stroke show differences in associations between systemic C3 levels and outcome. PLoS One, 8:e72133.

[50] Stokowska A, Olsson S, Holmegaard L, Jood K, Blomstrand C, Jern C, et al. (2011). Plasma C3 and C3a levels in cryptogenic and large-vessel disease stroke: associations with outcome. Cerebrovasc Dis, 32:114-122.

[51] Zhang B, Yang N, Gao C (2015). Is plasma C3 and C4 levels useful in young cerebral ischemic stroke patients? Associations with prognosis at 3 months. $\mathbf{J}$ Thromb Thrombolysis, 39:209-214.

[52] Olsson S, Stokowska A, Holmegaard L, Jood K, Blomstrand C, Pekna M, et al. (2011). Genetic variation in complement component $\mathrm{C} 3$ shows association with ischaemic stroke. Eur J Neurol, 18:1272-1274.

[53] Veerhuis R, Nielsen HM, Tenner AJ (2011). Complement in the brain. Mol Immunol, 48:15921603.

[54] Woodruff TM, Ager RR, Tenner AJ, Noakes PG, Taylor SM (2010). The role of the complement system and the activation fragment $\mathrm{C} 5 \mathrm{a}$ in the central nervous system. Neuromolecular Med, 12:179-192.

[55] Barnum SR (1995). Complement biosynthesis in the central nervous system. Crit Rev Oral Biol Med, 6:132-146.

[56] Hosokawa M, Klegeris A, Maguire J, McGeer PL (2003). Expression of complement messenger RNAs and proteins by human oligodendroglial cells. Glia, 42:417-423.

[57] Maranto J, Rappaport J, Datta PK (2008). Regulation of complement component $\mathrm{C} 3$ in astrocytes by ILlbeta and morphine. J Neuroimmune Pharmacol, 3:43-51.

[58] Morita H, Suzuki K, Mori N, Yasuhara O (2006). Occurrence of complement protein $\mathrm{C} 3$ in dying pyramidal neurons in rat hippocampus after systemic administration of kainic acid. Neurosci Lett, 409:3540.

[59] Yu JX, Bradt BM, Cooper NR (2002). Constitutive expression of proinflammatory complement components by subsets of neurons in the central nervous system. J Neuroimmunol, 123:91-101.

[60] Walker DG, Kim SU, McGeer PL (1995). Complement and cytokine gene expression in cultured microglial derived from postmortem human brains. J Neurosci Res, 40:478-493.

[61] Huang Y, Qiao F, Atkinson C, Holers VM, Tomlinson $S$ (2008). A novel targeted inhibitor of the alternative pathway of complement and its therapeutic application in ischemia/reperfusion injury. J Immunol, 181:80688076.

[62] Satyam A, Kannan L, Matsumoto N, Geha M, Lapchak PH (2017). Intracellular Activation of Complement 3 Is Responsible for Intestinal Tissue Damage during Mesenteric Ischemia. 198:788-797.

[63] Cowell RM, Plane JM, Silverstein FS (2003). Complement activation contributes to hypoxicischemic brain injury in neonatal rats. $\mathrm{J}$ Neurosci, 23:9459-9468.

[64] Figueroa E, Gordon LE, Feldhoff PW, Lassiter HA (2005). The administration of cobra venom factor reduces post-ischemic cerebral injury in adult and neonatal rats. Neurosci Lett, 380:48-53.

[65] Yang J, Ahn HN, Chang M, Narasimhan P, Chan PH, Song YS (2013). Complement component 3 inhibition by an antioxidant is neuroprotective after cerebral ischemia and reperfusion in mice. $\mathrm{J}$ Neurochem, 124:523-535.

[66] Ducruet AF, Sosunov SA, Zacharia BE, Gorski J, Yeh ML, Derosa P, et al. (2011). The Neuroprotective Effect of Genetic Mannose-binding Lectin Deficiency is not Sustained in the Sub-acute Phase of Stroke. Transl Stroke Res, 2:588-599.

[67] Rahpeymai Y, Hietala MA, Wilhelmsson U, Fotheringham A, Davies I, Nilsson AK, et al. (2006). Complement: a novel factor in basal and ischemiainduced neurogenesis. Embo j, 25:1364-1374.

[68] Atkinson C, Zhu H, Qiao F, Varela JC, Yu J, Song H, et al. (2006). Complement-dependent P-selectin expression and injury following ischemic stroke. J Immunol, 177:7266-7274.

[69] Hawksworth OA, Li XX, Coulthard LG, Wolvetang EJ, Woodruff TM (2017). New concepts on the therapeutic control of complement anaphylatoxin receptors. Mol Immunol, 89:36-43.

[70] Coulthard LG, Woodruff TM (2015). Is the complement activation product $\mathrm{C} 3 \mathrm{a}$ a proinflammatory molecule? Re-evaluating the evidence and the myth. 194:3542-3548.

[71] Legler DF, Loetscher M, Jones SA, Dahinden CA, Arock M, Moser B (1996). Expression of high- and low-affinity receptors for $\mathrm{C} 3 \mathrm{a}$ on the human mast cell line, HMC-1. Eur J Immunol, 26:753-758.

[72] Sayah S, Ischenko AM, Zhakhov A, Bonnard AS, Fontaine M (1999). Expression of cytokines by human astrocytomas following stimulation by $\mathrm{C} 3 \mathrm{a}$ and $\mathrm{C} 5 \mathrm{a}$ anaphylatoxins: specific increase in interleukin-6 mRNA expression. J Neurochem, 72:2426-2436. Jauneau AC, Ischenko A, Chan P, Fontaine M (2003). 
Complement component anaphylatoxins upregulate chemokine expression by human astrocytes. FEBS Lett, 537:17-22.

[74] Boos L, Campbell IL, Ames R, Wetsel RA, Barnum SR (2004). Deletion of the complement anaphylatoxin C3a receptor attenuates, whereas ectopic expression of $\mathrm{C} 3 \mathrm{a}$ in the brain exacerbates, experimental autoimmune encephalomyelitis. J Immunol, 173:4708-4714.

[75] Kildsgaard J, Hollmann TJ, Matthews KW, Bian K, Murad F, Wetsel RA (2000). Cutting edge: targeted disruption of the $\mathrm{C} 3 \mathrm{a}$ receptor gene demonstrates a novel protective anti-inflammatory role for $\mathrm{C} 3 \mathrm{a}$ in endotoxin-shock. J Immunol, 165:5406-5409.

[76] Boos L, Szalai AJ, Barnum SR (2005). C3a expressed in the central nervous system protects against LPSinduced shock. Neurosci Lett, 387:68-71.

[77] Heese K, Hock C, Otten U (1998). Inflammatory signals induce neurotrophin expression in human microglial cells. J Neurochem, 70:699-707.

[78] Kempermann G, Wiskott L, Gage FH (2004). Functional significance of adult neurogenesis. Curr Opin Neurobiol, 14:186-191.

[79] van Beek J, Nicole O, Ali C, Ischenko A, MacKenzie ET, Buisson A, et al. (2001). Complement anaphylatoxin $\mathrm{C} 3 \mathrm{a}$ is selectively protective against NMDA-induced neuronal cell death. Neuroreport, 12:289-293.

[80] Shinjyo N, Stahlberg A, Dragunow M, Pekny M, Pekna M (2009). Complement-derived anaphylatoxin $\mathrm{C} 3 \mathrm{a}$ regulates in vitro differentiation and migration of neural progenitor cells. Stem Cells, 27:2824-2832.

[81] Shinjyo N, de Pablo Y, Pekny M, Pekna M (2016). Complement Peptide C3a Promotes Astrocyte Survival in Response to Ischemic Stress. Mol Neurobiol, 53:3076-3087.

[82] Jarlestedt K, Rousset CI, Stahlberg A, Sourkova H, Atkins AL, Thornton C, et al. (2013). Receptor for complement peptide $\mathrm{C} 3 \mathrm{a}$ : a therapeutic target for neonatal hypoxic-ischemic brain injury. Faseb j, 27:3797-3804.

[83] Moran J, Stokowska A, Walker FR, Mallard C, Hagberg H, Pekna M (2017). Intranasal C3a treatment ameliorates cognitive impairment in a mouse model of neonatal hypoxic-ischemic brain injury. Exp Neurol, 290:74-84.

[84] Stokowska A, Atkins AL, Moran J, Pekny T, Bulmer L, Pascoe MC, et al. (2017). Complement peptide C3a stimulates neural plasticity after experimental brain ischaemia. Brain, 140:353-369.

[85] Harrison RA (2018). The properdin pathway: an "alternative activation pathway" or a "critical amplification loop" for C3 and C5 activation? Semin Immunopathol, 40:15-35.

[86] Alcorlo M, Lopez-Perrote A, Delgado S, Yebenes H, Subias M, Rodriguez-Gallego C, et al. (2015). Structural insights on complement activation. Febs j, 282:3883-3891.

[87] Janssen BJ, Christodoulidou A, McCarthy A, Lambris JD, Gros P (2006). Structure of C3b reveals conformational changes that underlie complement activity. Nature, 444:213-216.

[88] Tortajada A, Montes T, Martinez-Barricarte R, Morgan BP, Harris CL, de Cordoba SR (2009). The diseaseprotective complement factor $\mathrm{H}$ allotypic variant Ile62 shows increased binding affinity for $\mathrm{C} 3 \mathrm{~b}$ and enhanced cofactor activity. Hum Mol Genet, 18:34523461 .

[89] Merle NS, Church SE, Fremeaux-Bacchi V, Roumenina LT (2015). Complement System Part I Molecular Mechanisms of Activation and Regulation. Front Immunol, 6:262.

[90] Liszewski MK, Atkinson JP (2015). Complement regulators in human disease: lessons from modern genetics. J Intern Med, 277:294-305.

[91] Martinez-Barricarte R, Heurich M, Lopez-Perrote A, Tortajada A, Pinto S, Lopez-Trascasa M, et al. (2015). The molecular and structural bases for the association of complement $\mathrm{C} 3$ mutations with atypical hemolytic uremic syndrome. Mol Immunol, 66:263-273.

[92] Luzzatto L, Gianfaldoni G (2006). Recent advances in biological and clinical aspects of paroxysmal nocturnal hemoglobinuria. Int J Hematol, 84:104-112. Dragon-Durey MA, Blanc C, Garnier A, Hofer J, Sethi SK, Zimmerhackl LB (2010). Anti-factor H autoantibody-associated hemolytic uremic syndrome: review of literature of the autoimmune form of HUS. Semin Thromb Hemost, 36:633-640.

[94] Ricklin D, Reis ES, Lambris JD (2016). Complement in disease: a defence system turning offensive. Nat Rev Nephrol, 12:383-401.

[95] de Jorge EG, Yebenes H, Serna M, Tortajada A, Llorca O, de Cordoba SR (2018). How novel structures inform understanding of complement function. 40:314.

[96] Zipfel PF, Skerka C (2009). Complement regulators and inhibitory proteins. Nat Rev Immunol, 9:729-740.

[97] Papanastasiou M, Koutsogiannaki S, Sarigiannis Y (2017). Structural Implications for the Formation and Function of the Complement Effector Protein iC3b. 198:3326-3335.

[98] Craig ML, Waitumbi JN, Taylor RP(2005). Processing of C3b-opsonized immune complexes bound to noncomplement receptor 1 (CR1) sites on red cells: phagocytosis, transfer, and associations with CR1. J Immunol, 174:3059-3066.

[99] Tsuji S, Kaji K, Nagasawa S (1994). Activation of the alternative pathway of human complement by apoptotic human umbilical vein endothelial cells. J Biochem, 116:794-800.

[100] Matsui H, Tsuji S, Nishimura H, Nagasawa S (1994). Activation of the alternative pathway of complement by apoptotic Jurkat cells. FEBS Lett, 351:419-422.

[101] Takizawa F, Tsuji S, Nagasawa S (1996). Enhancement of macrophage phagocytosis upon iC $3 \mathrm{~b}$ deposition on apoptotic cells. FEBS Lett, 397:269-272.

[102] Mevorach D, Mascarenhas JO, Gershov D, Elkon KB (1998). Complement-dependent clearance of apoptotic cells by human macrophages. J Exp Med, 188:2313-2320. 
[103] Markiewski MM, Mastellos D, Tudoran R, DeAngelis RA, Strey CW, Franchini S, et al. (2004). C3a and C3b activation products of the third component of complement (C3) are critical for normal liver recovery after toxic injury. J Immunol, 173:747-754.

[104] Hasegawa M, Yada S, Liu MZ, Kamada N, MunozPlanillo R, Do N, et al. (2014). Interleukin-22 regulates the complement system to promote resistance against pathobionts after pathogen-induced intestinal damage. Immunity, 41:620-632.

[105] Lee YL, Lee KF, Xu JS, He QY, Chiu JF, Lee WM, et al. (2004). The embryotrophic activity of oviductal cell-derived complement $\mathrm{C} 3 \mathrm{~b}$ and $\mathrm{iC} 3 \mathrm{~b}$, a novel function of complement protein in reproduction. J Biol Chem, 279:12763-12768.

[106] Ramaglia V, Hughes TR, Donev RM, Ruseva MM, Wu $\mathrm{X}$, Huitinga I, et al. (2012). C3-dependent mechanism of microglial priming relevant to multiple sclerosis. Proc Natl Acad Sci U S A, 109:965-970.

[107] Birmingham DJ, Hebert LA (2001). CR1 and CR1-like: the primate immune adherence receptors. Immunol Rev, 180:100-111.

[108] Hess C, Schifferli JA (2003). Immune adherence revisited: novel players in an old game. News Physiol Sci, 18:104-108.

[109] Miwa T, Song WC (2001). Membrane complement regulatory proteins: insight from animal studies and relevance to human diseases. Int Immunopharmacol, $1: 445-459$.

[110] Ahearn JM, Fearon DT (1989). Structure and function of the complement receptors, CR1 (CD35) and CR2 (CD21). Adv Immunol, 46:183-219.

[111] Varela JC, Tomlinson S (2015). Complement: an overview for the clinician. Hematol Oncol Clin North Am, 29:409-427.

[112] Johansson JU, Brubaker WD, Javitz H, Bergen AW, Nishita D, Trigunaite A, et al. (2018). Peripheral complement interactions with amyloid beta peptide in Alzheimer's disease: Polymorphisms, structure, and function of complement receptor 1. Alzheimers Dement.

[113] Sarma JV, Ward PA (2011). The complement system. Cell Tissue Res, 343:227-235.

[114] Fonseca MI, Chu S, Pierce AL, Brubaker WD, Hauhart RE, Mastroeni D, et al. (2016). Analysis of the Putative Role of CR1 in Alzheimer's Disease: Genetic Association, Expression and Function. PLoS One, 11:e0149792.

[115] Yates D (2014). Synaptic plasticity: Microglial cellmediated depression. Nat Rev Neurosci, 15:280.

[116] Hannan JP (2016). The Structure-Function Relationships of Complement Receptor Type 2 (CR2; CD21). Curr Protein Pept Sci, 17:463-487.

[117] Gasque P, Chan P, Mauger C, Schouft MT, Singhrao S, Dierich MP, et al. (1996). Identification and characterization of complement $\mathrm{C} 3$ receptors on human astrocytes. J Immunol, 156:2247-2255.

[118] Molina H, Kinoshita T, Inoue K, Carel JC, Holers VM (1990). A molecular and immunochemical characterization of mouse CR2. Evidence for a single gene model of mouse complement receptors 1 and 2. J Immunol, 145:2974-2983.

[119] Molina H, Perkins SJ, Guthridge J, Gorka J, Kinoshita T, Holers VM (1995). Characterization of a complement receptor 2 (CR2, CD21) ligand binding site for $\mathrm{C} 3$. An initial model of ligand interaction with two linked short consensus repeat modules. J Immunol, 154:5426-5435.

[120] Singhrao SK, Neal JW, Rushmere NK, Morgan BP, Gasque P (1999). Differential expression of individual complement regulators in the brain and choroid plexus. Lab Invest, 79:1247-1259.

[121] Karch CM, Jeng AT, Nowotny P, Cady J, Cruchaga C, Goate AM (2012). Expression of novel Alzheimer's disease risk genes in control and Alzheimer's disease brains. PLoS One, 7:e50976.

[122] Allen M, Kachadoorian M, Carrasquillo MM, Karhade A, Manly L, Burgess JD, et al. (2015). Late-onset Alzheimer disease risk variants mark brain regulatory loci. Neurol Genet, 1:e15.

[123] Holton P, Ryten M, Nalls M, Trabzuni D, Weale ME, Hernandez D, et al. (2013). Initial assessment of the pathogenic mechanisms of the recently identified Alzheimer risk Loci. Ann Hum Genet, 77:85-105.

[124] Villegas-Llerena C, Phillips A, Garcia-Reitboeck P, Hardy J, Pocock JM (2016). Microglial genes regulating neuroinflammation in the progression of Alzheimer's disease. Curr Opin Neurobiol, 36:74-81.

[125] Lambert JC, Heath S, Even G, Campion D, Sleegers $\mathrm{K}$, Hiltunen $\mathrm{M}$, et al. (2009). Genome-wide association study identifies variants at CLU and CR1 associated with Alzheimer's disease. Nat Genet, 41:1094-1099.

[126] Pedraza O, Allen M, Jennette K, Carrasquillo M, Crook J, Serie D, et al. (2014). Evaluation of memory endophenotypes for association with CLU, CR1, and PICALM variants in black and white subjects. Alzheimers Dement, 10:205-213.

[127] Jin C, Li W, Yuan J, Xu W, Cheng Z (2012). Association of the CR1 polymorphism with late-onset Alzheimer's disease in Chinese Han populations: a meta-analysis. Neurosci Lett, 527:46-49.

[128] Corneveaux JJ, Myers AJ, Allen AN, Pruzin JJ, Ramirez M, Engel A, et al. (2010). Association of CR1, CLU and PICALM with Alzheimer's disease in a cohort of clinically characterized and neuropathologically verified individuals. Hum Mol Genet, 19:3295-3301.

[129] Crehan H, Hardy J, Pocock J (2013). Blockage of CR1 prevents activation of rodent microglia. Neurobiol Dis, 54:139-149.

[130] Alawieh A, Tomlinson S (2016). Injury site-specific targeting of complement inhibitors for treating stroke. Immunol Rev, 274:270-280.

[131] Holers VM, Kulik L (2007). Complement receptor 2, natural antibodies and innate immunity: Interrelationships in $\mathrm{B}$ cell selection and activation. Mol Immunol, 44:64-72.

[132] Fearon DT, Carter RH (1995). The CD19/CR2/TAPA1 complex of B lymphocytes: linking natural to 
acquired immunity. Annu Rev Immunol, 13:127-149.

[133] Carroll MC (2004). The complement system in B cell regulation. Mol Immunol, 41:141-146.

[134] Moriyama M, Fukuhara T, Britschgi M, He Y, Narasimhan R, Villeda S, et al. (2011). Complement receptor 2 is expressed in neural progenitor cells and regulates adult hippocampal neurogenesis. J Neurosci, 31:3981-3989.

[135] Neher MD, Rich MC, Keene CN, Weckbach S, Bolden AL, Losacco JT, et al. (2014). Deficiency of complement receptors CR2/CR1 in $\mathrm{Cr} 2(-) /(-)$ mice reduces the extent of secondary brain damage after closed head injury. J Neuroinflammation, 11:95.

[136] Lindblom RP, Berg A, Strom M, Aeinehband S, Dominguez CA, Al Nimer F, et al. (2015). Complement receptor 2 is up regulated in the spinal cord following nerve root injury and modulates the spinal cord response. J Neuroinflammation, 12:192.

[137] Sun S, Wang H, Zhao G, An Y, Guo Y, Du L, et al. (2011). Complement inhibition alleviates paraquatinduced acute lung injury. Am J Respir Cell Mol Biol, 45:834-842.

[138] Elvington A, Atkinson C, Zhu H, Yu J, Takahashi K, Stahl GL, et al. (2012). The alternative complement pathway propagates inflammation and injury in murine ischemic stroke. J Immunol, 189:4640-4647.

[139] Atkinson C, He S, Morris K, Qiao F, Casey S, Goddard M, et al. (2010). Targeted complement inhibitors protect against posttransplant cardiac ischemia and reperfusion injury and reveal an important role for the alternative pathway of complement activation. J Immunol, 185:7007-7013.

[140] Banda NK, Levitt B, Glogowska MJ, Thurman JM, Takahashi K, Stahl GL, et al. (2009). Targeted inhibition of the complement alternative pathway with complement receptor 2 and factor $\mathrm{H}$ attenuates collagen antibody-induced arthritis in mice. J Immunol, 183:5928-5937.

[141] Song H, He C, Knaak C, Guthridge JM, Holers VM, Tomlinson S (2003). Complement receptor 2mediated targeting of complement inhibitors to sites of complement activation. J Clin Invest, 111:1875-1885.

[142] Atkinson C, Song H, Lu B, Qiao F, Burns TA, Holers $\mathrm{VM}$, et al. (2005). Targeted complement inhibition by C3d recognition ameliorates tissue injury without apparent increase in susceptibility to infection. J Clin Invest, 115:2444-2453.

[143] Marshall KM, He S, Zhong Z, Atkinson C, Tomlinson $S$ (2014). Dissecting the complement pathway in hepatic injury and regeneration with a novel protective strategy. J Exp Med, 211:1793-1805.

[144] Schnabolk G, Beon MK, Tomlinson S, Rohrer B (2017). New Insights on Complement Inhibitor CD59 in Mouse Laser-Induced Choroidal Neovascularization: Mislocalization After Injury and Targeted Delivery for Protein Replacement. J Ocul Pharmacol Ther, 33:400-411.

[145] Myones BL, Ross GD (1987). Identification of a spontaneously shed fragment of B cell complement receptor type two (CR2) containing the C3d-binding site. Complement, 4:87-98.

[146] Ling N, Hansel T, Richardson P, Brown B (1991). Cellular origins of serum complement receptor type 2 in normal individuals and in hypogammaglobulinaemia. Clin Exp Immunol, 84:1622.

[147] Huemer HP, Larcher C, Prodinger WM, Petzer AL, Mitterer M, Falser N (1993). Determination of soluble CD21 as a parameter of B cell activation. Clin Exp Immunol, 93:195-199.

[148] Fremeaux-Bacchi V, Bernard I, Maillet F, Mani JC, Fontaine M, Bonnefoy JY, et al. (1996). Human lymphocytes shed a soluble form of CD21 (the $\mathrm{C} 3 \mathrm{dg} /$ Epstein-Barr virus receptor, CR2) that binds $\mathrm{iC} 3 \mathrm{~b}$ and CD23. Eur J Immunol, 26:1497-1503.

[149] Bajic G, Yatime L, Sim RB, Vorup-Jensen T, Andersen GR (2013). Structural insight on the recognition of surface-bound opsonins by the integrin I domain of complement receptor 3. Proc Natl Acad Sci U S A, 110:16426-16431.

[150] Masilamani M, von Kempis J, Illges H (2004). Decreased levels of serum soluble complement receptor-II (CR2/CD21) in patients with rheumatoid arthritis. Rheumatology (Oxford), 43:186-190.

[151] Lindblom RP, Aeinehband S, Strom M, Al Nimer F, Sandholm K, Khademi M, et al. (2016). Complement Receptor 2 is increased in cerebrospinal fluid of multiple sclerosis patients and regulates $\mathrm{C} 3$ function. Clin Immunol, 166-167:89-95.

[152] Toepfner N, Cepok S, Grummel V, Hemmer B (2012). The role of the Epstein-Barr virus receptor CD21 in multiple sclerosis. J Neuroimmunol, 242:47-51.

[153] Tomita M, Kadono T, Yazawa N, Kawashima T, Tamaki Z, Ashida R, et al. (2012). Serum levels of soluble CD21 in patients with systemic sclerosis. Rheumatol Int, 32:317-321.

[154] Ames RS, Li Y, Sarau HM, Nuthulaganti P, Foley JJ, Ellis C, et al. (1996). Molecular cloning and characterization of the human anaphylatoxin C3a receptor. J Biol Chem, 271:20231-20234.

[155] Crass T, Raffetseder U, Martin U, Grove M, Klos A, Kohl J, et al. (1996). Expression cloning of the human $\mathrm{C} 3 \mathrm{a}$ anaphylatoxin receptor $(\mathrm{C} 3 \mathrm{aR})$ from differentiated U-937 cells. Eur J Immunol, 26:19441950.

[156] Gasque P, Singhrao SK, Neal JW, Wang P, Sayah S, Fontaine M, et al. (1998). The receptor for complement anaphylatoxin $\mathrm{C} 3 \mathrm{a}$ is expressed by myeloid cells and nonmyeloid cells in inflamed human central nervous system: analysis in multiple sclerosis and bacterial meningitis. J Immunol, 160:3543-3554.

[157] Morgan BP, Gasque P (1996). Expression of complement in the brain: role in health and disease. Immunol Today, 17:461-466.

[158] Ember JA, Hugli TE (1997). Complement factors and their receptors. Immunopharmacology, 38:3-15.

[159] Laumonnier Y, Karsten CM, Kohl J (2017). Novel insights into the expression pattern of anaphylatoxin receptors in mice and men. Mol Immunol, 89:44-58.

[160] Quell KM, Karsten CM, Kordowski A, Almeida LN 
(2017). Monitoring C3aR Expression Using a Floxed tdTomato-C3aR Reporter Knock-in Mouse. 199:688706.

[161] Reca R, Mastellos D, Majka M, Marquez L, Ratajczak J, Franchini S, et al. (2003). Functional receptor for C3a anaphylatoxin is expressed by normal hematopoietic stem/progenitor cells, and $\mathrm{C} 3 \mathrm{a}$ enhances their homing-related responses to SDF-1. Blood, 101:3784-3793.

[162] Schraufstatter IU, Discipio RG, Zhao M, Khaldoyanidi SK (2009). C3a and C5a are chemotactic factors for human mesenchymal stem cells, which cause prolonged ERK1/2 phosphorylation. J Immunol, 182:3827-3836.

[163] Chmilewsky F, Jeanneau C, Laurent P, About I (2014). Pulp fibroblasts synthesize functional complement proteins involved in initiating dentin-pulp regeneration. Am J Pathol, 184:1991-2000.

[164] Davoust N, Jones J, Stahel PF, Ames RS, Barnum SR (1999). Receptor for the C3a anaphylatoxin is expressed by neurons and glial cells. Glia, 26:201-211.

[165] O'Barr SA, Caguioa J, Gruol D, Perkins G, Ember JA, Hugli T, et al. (2001). Neuronal expression of a functional receptor for the $\mathrm{C} 5 \mathrm{a}$ complement activation fragment. J Immunol, 166:4154-4162.

[166] Nataf S, Stahel PF, Davoust N, Barnum SR (1999). Complement anaphylatoxin receptors on neurons: new tricks for old receptors? Trends Neurosci, 22:397-402.

[167] Pedersen ED, Froyland E, Kvissel AK, Pharo AM, Skalhegg BS, Rootwelt T, et al. (2007). Expression of complement regulators and receptors on human NT2$\mathrm{N}$ neurons--effect of hypoxia and reoxygenation. Mol Immunol, 44:2459-2468.

[168] Benard M, Raoult E, Vaudry D, Leprince J, FalluelMorel A, Gonzalez BJ, et al. (2008). Role of complement anaphylatoxin receptors $(\mathrm{C} 3 \mathrm{aR}, \mathrm{C} 5 \mathrm{aR})$ in the development of the rat cerebellum. Mol Immunol, 45:3767-3774.

[169] Zhang C, Wang C, Li Y, Miwa T, Liu C, Cui W, et al. (2017). Complement C3a signaling facilitates skeletal muscle regeneration by regulating monocyte function and trafficking. Nat Commun, 8:2078.

[170] Grajales-Esquivel E, Luz-Madrigal A, Bierly J, Haynes T, Reis ES, Han Z, et al. (2017). Complement component $\mathrm{C} 3 \mathrm{aR}$ constitutes a novel regulator for chick eye morphogenesis. Dev Biol, 428:88-100.

[171] Crider A, Feng T, Pandya CD, Davis T, Nair A, Ahmed AO, et al. (2018). Complement component 3 a receptor deficiency attenuates chronic stress-induced monocyte infiltration and depressive-like behavior. Brain Behav Immun, 70:246-256.

[172] Lian H, Litvinchuk A (2016). Astrocyte-Microglia Cross Talk through Complement Activation Modulates Amyloid Pathology in Mouse Models of Alzheimer's Disease. J Neurosci, 36:577-589.

[173] Van Beek J, Bernaudin M, Petit E, Gasque P, Nouvelot A, MacKenzie ET, et al. (2000). Expression of receptors for complement anaphylatoxins $\mathrm{C} 3 \mathrm{a}$ and C5a following permanent focal cerebral ischemia in the mouse. Exp Neurol, 161:373-382.
[174] Andrew F Ducruet BGH, William J Mack, Sergei A Sosunov, Marc L Otten, David J Fusco, Zachary L Hickman, Grace H Kim, Ricardo J Komotar, J Mocco, E Sander Connolly (2008). C3a Receptor Modulation of Granulocyte Infiltration after Murine Focal Cerebral Ischemia is Reperfusion Dependent. J Cereb Blood Flow Metab, 28:1048-1058.

[175] Sauter RJ, Sauter M, Reis ES, Emschermann FN, Nording H, Ebenhoch S, et al. (2018). A Functional Relevance of the Anaphylatoxin Receptor C3aR for Platelet Function and Arterial Thrombus Formation Marks an Intersection Point Between Innate Immunity and Thrombosis. Circulation.

[176] Ren W, Liu Y, Wang X (2018). The Complement C3aC3aR Axis Promotes Development of Thoracic Aortic Dissection via Regulation of MMP2 Expression. 200:1829-1838.

[177] Wu F, Zou Q, Ding X, Shi D, Zhu X, Hu W, et al. (2016). Complement component C3a plays a critical role in endothelial activation and leukocyte recruitment into the brain. J Neuroinflammation, $13: 23$.

[178] Nozaki M, Raisler BJ, Sakurai E, Sarma JV, Barnum SR, Lambris JD, et al. (2006). Drusen complement components $\mathrm{C} 3 \mathrm{a}$ and $\mathrm{C} 5 \mathrm{a}$ promote choroidal neovascularization. Proc Natl Acad Sci U S A, 103:2328-2333.

[179] Khan SQ, Khan I, Gupta V (2018). CD11b Activity Modulates Pathogenesis of Lupus Nephritis. Front Med (Lausanne), 5:52.

[180] Hynes RO (2002). Integrins: bidirectional, allosteric signaling machines. Cell, 110:673-687.

[181] Erdei A, Lukacsi S, Macsik-Valent B, Nagy-Balo Z, Kurucz I, Bajtay Z (2017). Non-identical twins: Different faces of CR3 and CR4 in myeloid and lymphoid cells of mice and men. Semin Cell Dev Biol. [182] Podolnikova NP, Podolnikov AV, Haas TA, Lishko VK, Ugarova TP (2015). Ligand recognition specificity of leukocyte integrin alphaMbeta2 (Mac-1, $\mathrm{CD} 11 \mathrm{~b} / \mathrm{CD} 18)$ and its functional consequences. Biochemistry, 54:1408-1420.

[183] Yakubenko VP, Lishko VK, Lam SC, Ugarova TP (2002). A molecular basis for integrin alphaMbeta 2 ligand binding promiscuity. J Biol Chem, 277:4863548642.

[184] Coxon A, Rieu P, Barkalow FJ, Askari S, Sharpe AH, von Andrian UH, et al. (1996). A novel role for the beta 2 integrin CD11b/CD18 in neutrophil apoptosis: a homeostatic mechanism in inflammation. Immunity, 5:653-666.

[185] Ding ZM, Babensee JE, Simon SI, Lu H, Perrard JL, Bullard DC, et al. (1999). Relative contribution of LFA-1 and Mac-1 to neutrophil adhesion and migration. J Immunol, 163:5029-5038.

[186] Prince JE, Brayton CF, Fossett MC, Durand JA, Kaplan SL, Smith CW, et al. (2001). The differential roles of LFA-1 and Mac-1 in host defense against systemic infection with Streptococcus pneumoniae. J Immunol, 166:7362-7369.

[187] Fagerholm SC, Varis M, Stefanidakis M, Hilden TJ, 
Gahmberg CG (2006). alpha-Chain phosphorylation of the human leukocyte CD11b/CD18 (Mac-1) integrin is pivotal for integrin activation to bind ICAMs and leukocyte extravasation. Blood, 108:3379-3386.

[188] Faridi MH, Khan SQ, Zhao W, Lee HW, Altintas MM, Zhang K, et al. (2017). CD11b activation suppresses TLR-dependent inflammation and autoimmunity in systemic lupus erythematosus. J Clin Invest, 127:1271-1283.

[189] Han C, Jin J, Xu S, Liu H, Li N, Cao X (2010). Integrin $\mathrm{CD} 11 \mathrm{~b}$ negatively regulates TLR-triggered inflammatory responses by activating Syk and promoting degradation of MyD88 and TRIF via Cbl-b. Nat Immunol, 11:734-742.

[190] Means TK, Luster AD (2010). Integrins limit the Toll. Nat Immunol, 11:691-693.

[191] Roberts AL, Furnrohr BG, Vyse TJ, Rhodes B (2016). The complement receptor 3 (CD11b/CD18) agonist Leukadherin-1 suppresses human innate inflammatory signalling. Clin Exp Immunol, 185:361-371.

[192] Altieri DC, Edgington TS (1988). The saturable high affinity association of factor $\mathrm{X}$ to ADP-stimulated monocytes defines a novel function of the Mac-1 receptor. J Biol Chem, 263:7007-7015.

[193] Ginsberg MH, Du X, Plow EF (1992). Inside-out integrin signalling. Curr Opin Cell Biol, 4:766-771.

[194] Ross GD, Reed W, Dalzell JG, Becker SE, Hogg N (1992). Macrophage cytoskeleton association with CR3 and CR4 regulates receptor mobility and phagocytosis of iC3b-opsonized erythrocytes. J Leukoc Biol, 51:109-117.

[195] Graham IL, Gresham HD, Brown EJ (1989). An immobile subset of plasma membrane CD11b/CD18 (Mac-1) is involved in phagocytosis of targets recognized by multiple receptors. J Immunol, 142:2352-2358.

[196] Phillipson M, Heit B, Colarusso P, Liu L, Ballantyne CM, Kubes P (2006). Intraluminal crawling of neutrophils to emigration sites: a molecularly distinct process from adhesion in the recruitment cascade. $\mathrm{J}$ Exp Med, 203:2569-2575.

[197] Dupuy AG, Caron E (2008). Integrin-dependent phagocytosis: spreading from microadhesion to new concepts. J Cell Sci, 121:1773-1783.

[198] Alexander JJ, Chaves LD, Chang A, Jacob A, Ritchie M, Quigg RJ (2015). CD11b is protective in complement-mediated immune complex glomerulonephritis. Kidney Int, 87:930-939.

[199] Ehirchiou D, Xiong Y, Xu G, Chen W, Shi Y, Zhang L (2007). CD11b facilitates the development of peripheral tolerance by suppressing Th17 differentiation. J Exp Med, 204:1519-1524.

[200] Amarilyo G, Verbovetski I, Atallah M, Grau A, Wiser G, Gil O, et al. (2010). iC3b-opsonized apoptotic cells mediate a distinct anti-inflammatory response and transcriptional NF-kappaB-dependent blockade. Eur J Immunol, 40:699-709.

[201] Rhodes B, Furnrohr BG, Roberts AL, Tzircotis G, Schett G, Spector TD, et al. (2012). The rs1143679
(R77H) lupus associated variant of ITGAM (CD11b) impairs complement receptor 3 mediated functions in human monocytes. Ann Rheum Dis, 71:2028-2034.

[202] Fossati-Jimack L, Ling GS, Cortini A, Szajna M, Malik TH, McDonald JU, et al. (2013). Phagocytosis is the main CR3-mediated function affected by the lupus-associated variant of CD11b in human myeloid cells. PLoS One, 8:e57082.

[203] Norris GT, Smirnov I (2018). Neuronal integrity and complement control synaptic material clearance by microglia after CNS injury. 215:1789-1801.

[204] Marin-Teva JL, Dusart I, Colin C, Gervais A, van Rooijen N, Mallat M (2004). Microglia promote the death of developing Purkinje cells. Neuron, 41:535547.

[205] Wakselman S, Bechade C, Roumier A, Bernard D, Triller A, Bessis A (2008). Developmental neuronal death in hippocampus requires the microglial CD11b integrin and DAP12 immunoreceptor. J Neurosci, 28:8138-8143.

[206] Presumey J, Bialas AR, Carroll MC (2017). Complement System in Neural Synapse Elimination in Development and Disease. Adv Immunol, 135:53-79.

[207] Zabel MK, Kirsch WM (2013). From development to dysfunction: microglia and the complement cascade in CNS homeostasis. Ageing Res Rev, 12:749-756.

[208] Gasque P, Neal JW, Singhrao SK, McGreal EP, Dean YD, Van BJ, et al. (2002). Roles of the complement system in human neurodegenerative disorders: proinflammatory and tissue remodeling activities. Mol Neurobiol, 25:1-17.

[209] Harry GJ (2013). Microglia during development and aging. Pharmacol Ther, 139:313-326.

[210] Neumann H, Kotter MR, Franklin RJ (2009). Debris clearance by microglia: an essential link between degeneration and regeneration. Brain, 132:288-295.

[211] Schafer DP, Lehrman EK, Kautzman AG, Koyama R, Mardinly AR, Yamasaki R, et al. (2012). Microglia sculpt postnatal neural circuits in an activity and complement-dependent manner. Neuron, 74:691-705.

[212] Schafer DP, Stevens B (2010). Synapse elimination during development and disease: immune molecules take centre stage. Biochem Soc Trans, 38:476-481.

[213] Hong S, Beja-Glasser VF, Nfonoyim BM, Frouin A, Li S, Ramakrishnan S, et al. (2016). Complement and microglia mediate early synapse loss in Alzheimer mouse models. Science, 352:712-716.

[214] Haure-Mirande JV, Audrain M, Fanutza T, Kim SH, Klein WL, Glabe C, et al. (2017). Deficiency of TYROBP, an adapter protein for TREM2 and CR3 receptors, is neuroprotective in a mouse model of early Alzheimer's pathology. Acta Neuropathol, 134:769788.

[215] Lambert JC, Ibrahim-Verbaas CA, Harold D, Naj AC, Sims R, Bellenguez C, et al. (2013). Meta-analysis of 74,046 individuals identifies 11 new susceptibility loci for Alzheimer's disease. Nat Genet, 45:1452-1458.

[216] Fu H, Liu B, Frost JL, Hong S, Jin M, Ostaszewski B, et al. (2012). Complement component C3 and complement receptor type 3 contribute to the 
phagocytosis and clearance of fibrillar Abeta by microglia. Glia, 60:993-1003.

[217] Czirr E, Castello NA, Mosher KI, Castellano JM (2017). Microglial complement receptor 3 regulates brain Abeta levels through secreted proteolytic activity. 214:1081-1092.

[218] Zhang J, Malik A, Choi HB, Ko RW, Dissing-Olesen L, MacVicar BA (2014). Microglial CR3 activation triggers long-term synaptic depression in the hippocampus via NADPH oxidase. Neuron, 82:195207.

[219] Ma Y, Wang J, Wang Y, Yang GY (2017). The biphasic function of microglia in ischemic stroke. Prog Neurobiol, 157:247-272.

[220] Wang R, Li J, Duan Y, Tao Z, Zhao H, Luo Y (2017). Effects of Erythropoietin on Gliogenesis during Cerebral Ischemic/Reperfusion Recovery in Adult Mice. Aging Dis, 8:410-419.

[221] Zhang C, Zhu Y, Wang S, Zachory Wei Z, Jiang MQ, Zhang Y, et al. (2018). Temporal Gene Expression Profiles after Focal Cerebral Ischemia in Mice. Aging Dis, 9:249-261.

[222] Zhao G, Cheng XW, Piao L, Hu L, Lei Y, Yang G, et al. (2017). The Soluble VEGF Receptor sFlt-1 Contributes to Impaired Neovascularization in Aged Mice. Aging Dis, 8:287-300.

[223] Milde R, Ritter J, Tennent GA, Loesch A, Martinez FO, Gordon S, et al. (2015). Multinucleated Giant Cells Are Specialized for Complement-Mediated Phagocytosis and Large Target Destruction. Cell Rep, 13:1937-1948.

[224] Rotshenker S (2003). Microglia and macrophage activation and the regulation of complement-receptor3 (CR3/MAC-1)-mediated myelin phagocytosis in injury and disease. J Mol Neurosci, 21:65-72.

[225] Lalancette-Hebert M, Gowing G, Simard A, Weng YC, Kriz J (2007). Selective ablation of proliferating microglial cells exacerbates ischemic injury in the brain. J Neurosci, 27:2596-2605.

[226] Chen C, Li T, Zhao Y, Qian Y, Li X, Dai X, et al. (2018). Platelet glycoprotein receptor $\mathrm{Ib}$ blockade ameliorates experimental cerebral ischemiareperfusion injury by strengthening the blood-brain barrier function and anti-thrombo-inflammatory property. Brain Behav Immun, 69:255-263.

[227] Su EJ, Cao C, Fredriksson L, Nilsson I, Stefanitsch C, Stevenson TK, et al. (2017). Microglial-mediated PDGF-CC activation increases cerebrovascular permeability during ischemic stroke. 134:585-604.

[228] Soriano SG, Coxon A, Wang YF, Frosch MP, Lipton SA, Hickey PR, et al. (1999). Mice deficient in Mac-1 (CD11b/CD18) are less susceptible to cerebral ischemia/reperfusion injury. Stroke, 30:134-139.

[229] Zhang ZG, Chopp M, Tang WX, Jiang N, Zhang RL (1995). Postischemic treatment (2-4 h) with antiCD11b and anti-CD18 monoclonal antibodies are neuroprotective after transient $(2 \mathrm{~h})$ focal cerebral ischemia in the rat. Brain Res, 698:79-85.

[230] Chen H, Chopp M, Zhang RL, Bodzin G, Chen Q, Rusche JR, et al. (1994). Anti-CD11b monoclonal antibody reduces ischemic cell damage after transient focal cerebral ischemia in rat. Ann Neurol, 35:458-463. Harokopakis E, Albzreh MH, Martin MH, Hajishengallis G (2006). TLR2 transmodulates monocyte adhesion and transmigration via Rac1- and PI3K-mediated inside-out signaling in response to Porphyromonas gingivalis fimbriae. J Immunol, 176:7645-7656.

[232] Shimaoka M, Takagi J, Springer TA (2002). Conformational regulation of integrin structure and function. Annu Rev Biophys Biomol Struct, 31:485516.

[233] Shimaoka M, Springer TA (2004). Therapeutic antagonists and the conformational regulation of the beta2 integrins. Curr Top Med Chem, 4:1485-1495.

[234] Shimaoka M, Salas A, Yang W, Weitz-Schmidt G, Springer TA (2003). Small molecule integrin antagonists that bind to the beta 2 subunit I-like domain and activate signals in one direction and block them in the other. Immunity, 19:391-402.

[235] Moyle M, Foster DL, McGrath DE, Brown SM, Laroche Y, De Meutter J, et al. (1994). A hookworm glycoprotein that inhibits neutrophil function is a ligand of the integrin CD11b/CD18. J Biol Chem, 269:10008-10015.

[236] Jiang N, Moyle M, Soule HR, Rote WE, Chopp M (1995). Neutrophil inhibitory factor is neuroprotective after focal ischemia in rats. Ann Neurol, 38:935-942.

[237] Zhang L, Zhang ZG, Zhang RL, Lu M, Krams M, Chopp M (2003). Effects of a selective CD11b/CD18 antagonist and recombinant human tissue plasminogen activator treatment alone and in combination in a rat embolic model of stroke. Stroke, 34:1790-1795.

[238] Jiang N, Chopp M, Chahwala S (1998). Neutrophil inhibitory factor treatment of focal cerebral ischemia in the rat. Brain Res, 788:25-34.

[239] Arumugam TV, Magnus T, Woodruff TM, Proctor LM, Shiels IA, Taylor SM (2006). Complement mediators in ischemia-reperfusion injury. Clin Chim Acta, 374:33-45.

[240] Wagner E, Frank MM (2010). Therapeutic potential of complement modulation. Nat Rev Drug Discov, 9:4356.

[241] Klos A, Tenner AJ, Johswich KO, Ager RR, Reis ES, Kohl J (2009). The role of the anaphylatoxins in health and disease. Mol Immunol, 46:2753-2766.

[242] Hajishengallis G, Lambris JD (2010). Crosstalk pathways between Toll-like receptors and the complement system. Trends Immunol, 31:154-163.

[243] Hugli TE (1981). The structural basis for anaphylatoxin and chemotactic functions of $\mathrm{C} 3 \mathrm{a}, \mathrm{C} 4 \mathrm{a}$, and C5a. Crit Rev Immunol, 1:321-366.

[244] Mizuno M, Cole DS (2005). Novel C5a regulators in inflammatory disease. Expert Opin Investig Drugs, 14:807-821.

[245] Cain SA, Monk PN (2002). The orphan receptor C5L2 has high affinity binding sites for complement fragments C5a and C5a des-Arg(74). J Biol Chem, 277:7165-7169.

[246] Okinaga S, Slattery D, Humbles A, Zsengeller Z, 
Morteau O, Kinrade MB, et al. (2003). C5L2, a nonsignaling $\mathrm{C} 5 \mathrm{~A}$ binding protein. Biochemistry, 42:9406-9415.

[247] Haynes DR, Harkin DG, Bignold LP, Hutchens MJ, Taylor SM, Fairlie DP (2000). Inhibition of C5ainduced neutrophil chemotaxis and macrophage cytokine production in vitro by a new C5a receptor antagonist. Biochem Pharmacol, 60:729-733.

[248] Guo RF, Ward PA (2002). Mediators and regulation of neutrophil accumulation in inflammatory responses in lung: insights from the IgG immune complex model. Free Radic Biol Med, 33:303-310.

[249] Guo RF, Riedemann NC, Bernacki KD, Sarma VJ, Laudes IJ, Reuben JS, et al. (2003). Neutrophil C5a receptor and the outcome in a rat model of sepsis. Faseb j, 17:1889-1891.

[250] Zhang T, Garstka MA, Li K (2017). The Controversial C5a Receptor C5aR2: Its Role in Health and Disease. 2017:8193932.

[251] Gavrilyuk V, Kalinin S, Hilbush BS, Middlecamp A, McGuire S, Pelligrino D, et al. (2005). Identification of complement 5a-like receptor (C5L2) from astrocytes: characterization of anti-inflammatory properties. J Neurochem, 92:1140-1149.

[252] Ohno M, Hirata T, Enomoto M, Araki T, Ishimaru H, Takahashi TA (2000). A putative chemoattractant receptor, $\mathrm{C} 5 \mathrm{~L} 2$, is expressed in granulocyte and immature dendritic cells, but not in mature dendritic cells. Mol Immunol, 37:407-412.

[253] Scola AM, Higginbottom A, Partridge LJ, Reid RC, Woodruff T, Taylor SM, et al. (2007). The role of the N-terminal domain of the complement fragment receptor $\mathrm{C} 5 \mathrm{~L} 2$ in ligand binding. J Biol Chem, 282:3664-3671.

[254] Lee H, Whitfeld PL, Mackay CR (2008). Receptors for complement C5a. The importance of C5aR and the enigmatic role of C5L2. Immunol Cell Biol, 86:153160.

[255] Scola AM, Johswich KO, Morgan BP, Klos A, Monk PN (2009). The human complement fragment receptor, C5L2, is a recycling decoy receptor. Mol Immunol, 46:1149-1162.

[256] Rittirsch D, Flierl MA, Nadeau BA, Day DE, HuberLang M, Mackay CR, et al. (2008). Functional roles for C5a receptors in sepsis. Nat Med, 14:551-557.

[257] Cole DS, Morgan BP (2003). Beyond lysis: how complement influences cell fate. Clin Sci (Lond), 104:455-466.

[258] Morgan BP (1999). Regulation of the complement membrane attack pathway. Crit Rev Immunol, 19:173198.

[259] Morgan BP (1989). Complement membrane attack on nucleated cells: resistance, recovery and non-lethal effects. Biochem J, 264:1-14.

[260] Casas JP, Hingorani AD, Bautista LE, Sharma P (2004). Meta-analysis of genetic studies in ischemic stroke: thirty-two genes involving approximately 18,000 cases and 58,000 controls. Arch Neurol, 61:1652-1661.

[261] Bare LA, Morrison AC, Rowland CM, Shiffman D,
Luke MM, Iakoubova OA, et al. (2007). Five common gene variants identify elevated genetic risk for coronary heart disease. Genet Med, 9:682-689.

[262] Hoke M, Speidl W, Schillinger M, Minar E, Zehetmayer S, Schonherr M, et al. (2012). Polymorphism of the complement 5 gene and cardiovascular outcome in patients with atherosclerosis. Eur J Clin Invest, 42:921-926.

[263] Speidl WS, Exner M, Amighi J, Kastl SP, Zorn G, Maurer G, et al. (2005). Complement component C5a predicts future cardiovascular events in patients with advanced atherosclerosis. Eur Heart J, 26:2294-2299.

[264] Greisenegger S, Zehetmayer S, Bauer P, Endler G, Ferrari J, Lang W, et al. (2009). Polymorphisms in inflammatory genes and the risk of ischemic stroke and transient ischemic attack: results of a multilocus genotyping assay. Clin Chem, 55:134-138.

[265] Pedersen ED, Waje-Andreassen U, Vedeler CA, Aamodt G, Mollnes TE (2004). Systemic complement activation following human acute ischaemic stroke. Clin Exp Immunol, 137:117-122.

[266] Szeplaki G, Szegedi R, Hirschberg K, Gombos T, Varga L, Karadi I, et al. (2009). Strong complement activation after acute ischemic stroke is associated with unfavorable outcomes. Atherosclerosis, 204:315320.

[267] Huber-Lang M, Sarma JV, Zetoune FS, Rittirsch D, Neff TA, McGuire SR, et al. (2006). Generation of $\mathrm{C} 5 \mathrm{a}$ in the absence of $\mathrm{C} 3$ : a new complement activation pathway. Nat Med, 12:682-687.

[268] Orsini F, De Blasio D, Zangari R, Zanier ER, De Simoni MG (2014). Versatility of the complement system in neuroinflammation, neurodegeneration and brain homeostasis. Front Cell Neurosci, 8:380.

[269] Arumugam TV, Tang SC, Lathia JD, Cheng A, Mughal MR, Chigurupati S, et al. (2007). Intravenous immunoglobulin (IVIG) protects the brain against experimental stroke by preventing complementmediated neuronal cell death. Proc Natl Acad Sci U S A, 104:14104-14109.

[270] Costa C, Zhao L, Shen Y, Su X, Hao L, Colgan SP, et al. (2006). Role of complement component C5 in cerebral ischemia/reperfusion injury. Brain Res, 1100:142-151.

[271] Liu Q, He S, Groysman L, Shaked D, Russin J, Scotton $\mathrm{TC}$, et al. (2013). White matter injury due to experimental chronic cerebral hypoperfusion is associated with C5 deposition. PLoS One, 8:e84802.

[272] Wezel A, de Vries MR, Lagraauw HM, Foks AC, Kuiper J, Quax PH, et al. (2014). Complement factor C5a induces atherosclerotic plaque disruptions. J Cell Mol Med, 18:2020-2030.

[273] Li K, Zhou W (2013). Anaphylatoxins in organ transplantation. Semin Immunol, 25:20-28.

[274] Mulligan MS, Schmid E, Till GO, Hugli TE, Friedl HP, Roth RA, et al. (1997). C5a-dependent up-regulation in vivo of lung vascular P-selectin. J Immunol, 158:1857-1861.

[275] Foreman KE, Glovsky MM, Warner RL, Horvath SJ, Ward PA (1996). Comparative effect of C3a and C5a 
on adhesion molecule expression on neutrophils and endothelial cells. Inflammation, 20:1-9.

[276] Buono C, Come CE, Witztum JL, Maguire GF, Connelly PW, Carroll M, et al. (2002). Influence of C3 deficiency on atherosclerosis. Circulation, 105:30253031.

[277] Conroy A, Serghides L, Finney C, Owino SO, Kumar S, Gowda DC, et al. (2009). C5a enhances dysregulated inflammatory and angiogenic responses to malaria in vitro: potential implications for placental malaria. PLoS One, 4:e4953.

[278] Mahajan SD, Tutino VM, Redae Y, Meng H, Siddiqui A, Woodruff TM, et al. (2016). C5a induces caspasedependent apoptosis in brain vascular endothelial cells in experimental lupus. Immunology, 148:407-419.

[279] Pischke SE, Gustavsen A, Orrem HL, Egge KH, Courivaud F, Fontenelle H, et al. (2017). Complement factor 5 blockade reduces porcine myocardial infarction size and improves immediate cardiac function. Basic Res Cardiol, 112:20.

[280] Mehta G, Scheinman RI, Holers VM, Banda NK (2015). A New Approach for the Treatment of Arthritis in Mice with a Novel Conjugate of an Anti-C5aR1 Antibody and C5 Small Interfering RNA. J Immunol, 194:5446-5454.

[281] de Vries B, Kohl J, Leclercq WK, Wolfs TG, van Bijnen AA, Heeringa P, et al. (2003). Complement factor $\mathrm{C} 5 \mathrm{a}$ mediates renal ischemia-reperfusion injury independent from neutrophils. J Immunol, 170:38833889.

[282] Tuboly E, Futakuchi M, Varga G, Erces D, Tokes T, Meszaros A, et al. (2016). C5a inhibitor protects against ischemia/reperfusion injury in rat small intestine. Microbiol Immunol, 60:35-46.

[283] Nogrady M, Varga G, Szucs S, Kaszaki J, Boros M, Erces D (2017). [Effects of complement C5a inhibitor therapy in animal models of non-occlusive mesenteric ischemia]. Magy Seb, 70:221-231.

[284] Fletcher MP, Stahl GL, Longhurst JC (1993). C5ainduced myocardial ischemia: role for CD18dependent PMN localization and PMN-platelet interactions. Am J Physiol, 265:H1750-1761.

[285] Pavlovski D, Thundyil J, Monk PN, Wetsel RA, Taylor SM, Woodruff TM (2012). Generation of complement component $\mathrm{C} 5 \mathrm{a}$ by ischemic neurons promotes neuronal apoptosis. Faseb j, 26:3680-3690.

[286] Mukherjee P, Thomas S, Pasinetti GM (2008). Complement anaphylatoxin $\mathrm{C} 5 \mathrm{a}$ neuroprotects through regulation of glutamate receptor subunit 2 in vitro and in vivo. J Neuroinflammation, 5:5.

[287] Persson M, Pekna M, Hansson E, Ronnback L (2009). The complement-derived anaphylatoxin C5a increases microglial GLT-1 expression and glutamate uptake in a TNF-alpha-independent manner. Eur J Neurosci, 29:267-274.

[288] Rus H, Niculescu F (2001). The complement system in central nervous system diseases. Immunol Res, 24:79-86.

[289] Soane L, Rus H, Niculescu F, Shin ML (1999). Inhibition of oligodendrocyte apoptosis by sublytic

\section{[290]}

C5b-9 is associated with enhanced synthesis of bcl-2 and mediated by inhibition of caspase-3 activation. $\mathrm{J}$ Immunol, 163:6132-6138.

Cudrici C, Niculescu F, Jensen T, Zafranskaia E, Fosbrink M, Rus V, et al. (2006). C5b-9 terminal complex protects oligodendrocytes from apoptotic cell death by inhibiting caspase- 8 processing and upregulating FLIP. J Immunol, 176:3173-3180.

[291] Kilgore KS, Flory CM, Miller BF, Evans VM, Warren JS (1996). The membrane attack complex of complement induces interleukin-8 and monocyte chemoattractant protein-1 secretion from human umbilical vein endothelial cells. Am J Pathol, 149:953-961.

[292] Park CC, Shin ML, Simard JM (1997). The complement membrane attack complex and the bystander effect in cerebral vasospasm. J Neurosurg, 87:294-300.

[293] Danobeitia JS, Djamali A, Fernandez LA (2014). The role of complement in the pathogenesis of renal ischemia-reperfusion injury and fibrosis. Fibrogenesis Tissue Repair, 7:16.

[294] Mead RJ, Singhrao SK, Neal JW, Lassmann H, Morgan BP (2002). The membrane attack complex of complement causes severe demyelination associated with acute axonal injury. J Immunol, 168:458-465.

[295] Bellander BM, Singhrao SK, Ohlsson M, Mattsson P, Svensson M (2001). Complement activation in the human brain after traumatic head injury. $\mathrm{J}$ Neurotrauma, 18:1295-1311.

[296] Compston DA, Morgan BP, Campbell AK, Wilkins P, Cole G, Thomas ND, et al. (1989). Immunocytochemical localization of the terminal complement complex in multiple sclerosis. Neuropathol Appl Neurobiol, 15:307-316.

[297] Rogers J, Cooper NR, Webster S, Schultz J, McGeer PL, Styren SD, et al. (1992). Complement activation by beta-amyloid in Alzheimer disease. Proc Natl Acad Sci U S A, 89:10016-10020.

[298] Bradt BM, Kolb WP, Cooper NR (1998). Complement-dependent proinflammatory properties of the Alzheimer's disease beta-peptide. J Exp Med, 188:431-438.

[299] Schultz SJ, Aly H, Hasanen BM, Khashaba MT, Lear SC, Bendon RW, et al. (2005). Complement component 9 activation, consumption, and neuronal deposition in the post-hypoxic-ischemic central nervous system of human newborn infants. Neurosci Lett, 378:1-6.

[300] Imm MD, Feldhoff PW, Feldhoff RC, Lassiter HA (2002). The administration of complement component C9 augments post-ischemic cerebral infarction volume in neonatal rats. Neurosci Lett, 325:175-178.

[301] Harhausen D, Khojasteh U, Stahel PF, Morgan BP, Nietfeld W, Dirnagl U, et al. (2010). Membrane attack complex inhibitor CD59a protects against focal cerebral ischemia in mice. J Neuroinflammation, 7:15. [302] Gerard NP, Gerard C (1991). The chemotactic receptor for human C5a anaphylatoxin. Nature, 349:614-617.

[303] Laudes IJ, Chu JC, Huber-Lang M, Guo RF, 
Riedemann NC, Sarma JV, et al. (2002). Expression and function of $\mathrm{C} 5$ a receptor in mouse microvascular endothelial cells. J Immunol, 169:5962-5970.

[304] Drouin SM, Kildsgaard J, Haviland J, Zabner J, Jia HP, McCray PB, Jr., et al. (2001). Expression of the complement anaphylatoxin $\mathrm{C} 3 \mathrm{a}$ and $\mathrm{C} 5 \mathrm{a}$ receptors on bronchial epithelial and smooth muscle cells in models of sepsis and asthma. J Immunol, 166:2025-2032.

[305] Strainic MG, Liu J, Huang D, An F, Lalli PN, Muqim $\mathrm{N}$, et al. (2008). Locally produced complement fragments $\mathrm{C} 5 \mathrm{a}$ and $\mathrm{C} 3 \mathrm{a}$ provide both costimulatory and survival signals to naive CD4+ T cells. Immunity, 28:425-435.

[306] Fayyazi A, Scheel O, Werfel T, Schweyer S, Oppermann M, Gotze O, et al. (2000). The C5a receptor is expressed in normal renal proximal tubular but not in normal pulmonary or hepatic epithelial cells. Immunology, 99:38-45.

[307] Abe K, Miyazaki M, Koji T, Furusu A, NakamuraKurashige T, Nishino T, et al. (2001). Enhanced expression of complement $\mathrm{C} 5 \mathrm{a}$ receptor mRNA in human diseased kidney assessed by in situ hybridization. Kidney Int, 60:137-146.

[308] Gasque P, Singhrao SK, Neal JW, Gotze O, Morgan BP (1997). Expression of the receptor for complement $\mathrm{C} 5 \mathrm{a}$ (CD88) is up-regulated on reactive astrocytes, microglia, and endothelial cells in the inflamed human central nervous system. Am J Pathol, 150:31-41.

[309] Fusakio ME, Mohammed JP, Laumonnier Y, Hoebe K, Kohl J, Mattner J (2011). C5a regulates NKT and NK cell functions in sepsis. J Immunol, 187:5805-5812.

[310] Han G, Geng S, Li Y, Chen G, Wang R, Li X, et al. (2011). gammadeltaT-cell function in sepsis is modulated by $\mathrm{C} 5 \mathrm{a}$ receptor signalling. Immunology, 133:340-349.

[311] Woodruff TM, Costantini KJ, Crane JW, Atkin JD, Monk PN, Taylor SM, et al. (2008). The complement factor C5a contributes to pathology in a rat model of amyotrophic lateral sclerosis. J Immunol, 181:87278734.

[312] Benard M, Gonzalez BJ, Schouft MT, Falluel-Morel A, Vaudry D, Chan P, et al. (2004). Characterization of $\mathrm{C} 3 \mathrm{a}$ and $\mathrm{C} 5 \mathrm{a}$ receptors in rat cerebellar granule neurons during maturation. Neuroprotective effect of C5a against apoptotic cell death. J Biol Chem, 279:43487-43496.

[313] Farkas I, Takahashi M, Fukuda A, Yamamoto N, Akatsu H, Baranyi L, et al. (2003). Complement C5a receptor-mediated signaling may be involved in neurodegeneration in Alzheimer's disease. J Immunol, 170:5764-5771.

[314] Farkas I, Varju P, Szabo E, Hrabovszky E, Okada N, Okada $\mathrm{H}$, et al. (2008). Estrogen enhances expression of the complement $\mathrm{C} 5$ a receptor and the C5a-agonist evoked calcium influx in hormone secreting neurons of the hypothalamus. Neurochem Int, 52:846-856.

[315] Gasque P, Chan P, Fontaine M, Ischenko A, Lamacz M, Gotze O, et al. (1995). Identification and characterization of the complement $\mathrm{C} 5 \mathrm{a}$ anaphylatoxin receptor on human astrocytes. J Immunol, 155:4882-
4889.

[316] Ilschner S, Nolte C, Kettenmann H (1996). Complement factor C5a and epidermal growth factor trigger the activation of outward potassium currents in cultured murine microglia. Neuroscience, 73:11091120.

[317] Sayah S, Patte C, Gasque P, Chan P, Ischenko A, Vaudry H, et al. (1997). Characterization of rat C5a anaphylatoxin receptor $(\mathrm{C} 5 \mathrm{aR})$ : cloning of rat $\mathrm{C} 5 \mathrm{aR}$ cDNA and study of C5aR expression by rat astrocytes. Brain Res Mol Brain Res, 48:215-222.

[318] Singhrao SK, Neal JW, Morgan BP, Gasque P (1999). Increased complement biosynthesis by microglia and complement activation on neurons in Huntington's disease. Exp Neurol, 159:362-376.

[319] Fayyazi A, Sandau R, Duong LQ, Gotze O, Radzun HJ, Schweyer S, et al. (1999). C5a receptor and interleukin- 6 are expressed in tissue macrophages and stimulated keratinocytes but not in pulmonary and intestinal epithelial cells. Am J Pathol, 154:495-501.

[320] Nataf S, Davoust N, Barnum SR (1998). Kinetics of anaphylatoxin $\mathrm{C} 5 \mathrm{a}$ receptor expression during experimental allergic encephalomyelitis. J Neuroimmunol, 91:147-155.

[321] Gasque P, Dean YD, McGreal EP, VanBeek J, Morgan BP (2000). Complement components of the innate immune system in health and disease in the CNS. Immunopharmacology, 49:171-186.

[322] Lee JD, Levin SC, Willis EF, Li R, Woodruff TM, Noakes PG (2018). Complement components are upregulated and correlate with disease progression in the TDP-43(Q331K) mouse model of amyotrophic lateral sclerosis. J Neuroinflammation, 15:171.

[323] Stahel PF, Kariya K, Shohami E, Barnum SR, Eugster $\mathrm{H}$, Trentz O, et al. (2000). Intracerebral complement C5a receptor (CD88) expression is regulated by TNF and lymphotoxin-alpha following closed head injury in mice. J Neuroimmunol, 109:164-172.

[324] Crane JW, Baiquni GP, Sullivan RK, Lee JD, Sah P, Taylor SM, et al. (2009). The C5a anaphylatoxin receptor CD88 is expressed in presynaptic terminals of hippocampal mossy fibres. J Neuroinflammation, 6:34

[325] Hawksworth OA, Coulthard LG, Woodruff TM (2017). Complement in the fundamental processes of the cell. Mol Immunol, 84:17-25.

[326] Gorelik A, Sapir T, Haffner-Krausz R, Olender T, Woodruff TM (2017). Developmental activities of the complement pathway in migrating neurons. Nat Commun, 8:15096.

[327] Coulthard LG, Hawksworth OA, Li R, Balachandran A, Lee JD, Sepehrband F, Kurniawan N, et al. (2017) Complement C5aR1 Signaling Promotes Polarization and Proliferation of Embryonic Neural Progenitor Cells through PKCद. J Neurosci. 37:5395-5407.

[328] Hopken UE, Lu B, Gerard NP, Gerard C (1996). The C5a chemoattractant receptor mediates mucosal defence to infection. Nature, 383:86-89.

[329] Kohl J (2006). Drug evaluation: the C5a receptor antagonist PMX-53. Curr Opin Mol Ther, 8:529-538.

[330] Denny KJ, Coulthard LG, Jeanes A, Lisgo S, Simmons 
DG, Callaway LK, et al. (2013). C5a receptor signaling prevents folate deficiency-induced neural tube defects in mice. J Immunol, 190:3493-3499.

[331] Hernandez MX, Jiang S, Cole TA, Chu SH, Fonseca MI, Fang MJ, et al. (2017). Prevention of C5aR1 signaling delays microglial inflammatory polarization, favors clearance pathways and suppresses cognitive loss. Mol Neurodegener, 12:66.

[332] Zhang C, Li Y, Wang C, Wu Y, Cui W, Miwa T, et al. (2014). Complement 5a receptor mediates angiotensin II-induced cardiac inflammation and remodeling. Arterioscler Thromb Vasc Biol, 34:1240-1248.

[333] Zheng X, Zhang X, Feng B, Sun H, Suzuki M, Ichim $\mathrm{T}$, et al. (2008). Gene silencing of complement C5a receptor using siRNA for preventing ischemia/reperfusion injury. Am J Pathol, 173:973980.

[334] Woodruff TM, Arumugam TV, Shiels IA, Reid RC, Fairlie DP, Taylor SM (2004). Protective effects of a potent $\mathrm{C} 5$ a receptor antagonist on experimental acute limb ischemia-reperfusion in rats. J Surg Res, 116:8190.

[335] Heller T, Hennecke M, Baumann U, Gessner JE, zu Vilsendorf AM, Baensch M, et al. (1999). Selection of a $\mathrm{C} 5 \mathrm{a}$ receptor antagonist from phage libraries attenuating the inflammatory response in immune complex disease and ischemia/reperfusion injury. $\mathrm{J}$ Immunol, 163:985-994.

[336] Arumugam TV, Shiels IA, Woodruff TM, Reid RC, Fairlie DP, Taylor SM (2002). Protective effect of a new $\mathrm{C} 5 \mathrm{a}$ receptor antagonist against ischemiareperfusion injury in the rat small intestine. J Surg Res, 103:260-267.

[337] Arumugam TV, Woodruff TM, Stocks SZ, Proctor LM, Pollitt S, Shiels IA, et al. (2004). Protective effect of a human $\mathrm{C} 5 \mathrm{a}$ receptor antagonist against hepatic ischaemia-reperfusion injury in rats. $\mathrm{J}$ Hepatol, 40:934-941.

[338] Sewell DL, Nacewicz B, Liu F, Macvilay S, Erdei A, Lambris JD, et al. (2004). Complement C3 and C5 play critical roles in traumatic brain cryoinjury: blocking effects on neutrophil extravasation by $\mathrm{C} 5 \mathrm{a}$ receptor antagonist. J Neuroimmunol, 155:55-63.

[339] Garrett MC, Otten ML, Starke RM, Komotar RJ, Magotti P, Lambris JD, et al. (2009). Synergistic neuroprotective effects of $\mathrm{C} 3 \mathrm{a}$ and $\mathrm{C} 5 \mathrm{a}$ receptor blockade following intracerebral hemorrhage. Brain Res, 1298:171-177.

[340] Fonseca MI, Ager RR, Chu SH, Yazan O, Sanderson SD, LaFerla FM, et al. (2009). Treatment with a C5aR antagonist decreases pathology and enhances behavioral performance in murine models of Alzheimer's disease. J Immunol, 183:1375-1383.

[341] Barnum SR, Ames RS, Maycox PR, Hadingham SJ, Meakin J, Harrison D, et al. (2002). Expression of the complement $\mathrm{C} 3 \mathrm{a}$ and $\mathrm{C} 5 \mathrm{a}$ receptors after permanent focal ischemia: An alternative interpretation. Glia, 38:169-173.

[342] Shah TA, Nejad JE, Pallera HK, Lattanzio FA, Farhat R, Kumar PS, et al. (2017). Therapeutic hypothermia modulates complement factor $\mathrm{C} 3 \mathrm{a}$ and $\mathrm{C} 5 \mathrm{a}$ levels in a rat model of hypoxic ischemic encephalopathy. Pediatr Res, 81:654-662.

[343] Monk PN, Scola AM, Madala P, Fairlie DP (2007). Function, structure and therapeutic potential of complement C5a receptors. Br J Pharmacol, 152:429448.

[344] Karsten CM, Wiese AV (2017). Monitoring C5aR2 Expression Using a Floxed tdTomato-C5aR2 KnockIn Mouse. 199:3234-3248.

[345] Li R, Coulthard LG, Wu MC, Taylor SM, Woodruff TM (2013). C5L2: a controversial receptor of complement anaphylatoxin, C5a. Faseb j, 27:855-864.

[346] Colley CS, Popovic B, Sridharan S, Debreczeni JE, Hargeaves D, Fung M, et al. (2018). Structure and characterization of a high affinity $\mathrm{C} 5 \mathrm{a}$ monoclonal antibody that blocks binding to $\mathrm{C} 5 \mathrm{aR} 1$ and $\mathrm{C} 5 \mathrm{aR} 2$ receptors. MAbs, 10:104-117.

[347] Bamberg CE, Mackay CR, Lee H, Zahra D, Jackson J, Lim YS, et al. (2010). The C5a receptor (C5aR) C5L2 is a modulator of $\mathrm{C} 5 \mathrm{aR}$-mediated signal transduction. J Biol Chem, 285:7633-7644.

[348] Wang R, Lu B, Gerard C, Gerard NP (2013). Disruption of the complement anaphylatoxin receptor C5L2 exacerbates inflammation in allergic contact dermatitis. J Immunol, 191:4001-4009.

[349] Croker DE, Halai R, Kaeslin G, Wende E, Fehlhaber $\mathrm{B}, \mathrm{K} \operatorname{los} \mathrm{A}$, et al. (2014). C5a2 can modulate ERK1/2 signaling in macrophages via heteromer formation with $\mathrm{C} 5 \mathrm{a} 1$ and beta-arrestin recruitment. Immunol Cell Biol, 92:631-639.

[350] Gerard NP, Lu B, Liu P, Craig S, Fujiwara Y, Okinaga $S$, et al. (2005). An anti-inflammatory function for the complement anaphylatoxin C5a-binding protein, C5L2. J Biol Chem, 280:39677-39680.

[351] Zhang X, Schmudde I, Laumonnier Y, Pandey MK, Clark JR, Konig P, et al. (2010). A critical role for C5L2 in the pathogenesis of experimental allergic asthma. J Immunol, 185:6741-6752.

[352] Chen NJ, Mirtsos C, Suh D, Lu YC, Lin WJ, McKerlie C, et al. (2007). C5L2 is critical for the biological activities of the anaphylatoxins C5a and C3a. Nature, 446:203-207.

[353] Bosmann M, Grailer JJ, Ruemmler R, Russkamp NF, Zetoune FS, Sarma JV, et al. (2013). Extracellular histones are essential effectors of C5aR- and C5L2mediated tissue damage and inflammation in acute lung injury. Faseb j, 27:5010-5021.

[354] Poppelaars F, van Werkhoven MB, Kotimaa J, Veldhuis ZJ, Ausema A, Broeren SGM, et al. (2017). Critical role for complement receptor $\mathrm{C} 5 \mathrm{aR} 2$ in the pathogenesis of renal ischemia-reperfusion injury. Faseb j, 31:3193-3204.

[355] Pundir P, MacDonald CA, Kulka M (2015). The Novel Receptor C5aR2 Is Required for C5a-Mediated Human Mast Cell Adhesion, Migration, and Proinflammatory Mediator Production. J Immunol, 195:2774-2787.

[356] Bosmann M, Haggadone MD, Zetoune FS, Sarma JV, Ward PA (2013). The interaction between C5a and 
both $\mathrm{C} 5 \mathrm{aR}$ and $\mathrm{C} 5 \mathrm{~L} 2$ receptors is required for production of G-CSF during acute inflammation. Eur J Immunol, 43:1907-1913.

[357] Reis ES, Mastellos DC, Ricklin D, Mantovani A, Lambris JD (2018). Complement in cancer: untangling an intricate relationship. Nat Rev Immunol, 18:5-18.

[358] Mastellos DC, Ricklin D, Hajishengallis E, Hajishengallis G, Lambris JD (2016). Complement therapeutics in inflammatory diseases: promising drug candidates for C3-targeted intervention. Mol Oral Microbiol, 31:3-17.

[359] Brennan FH, Lee JD, Ruitenberg MJ, Woodruff TM (2016). Therapeutic targeting of complement to modify disease course and improve outcomes in neurological conditions. Semin Immunol, 28:292-308.

[360] Ricklin D, Lambris JD (2013). Progress and trends in complement therapeutics. Adv Exp Med Biol, 735:122.

[361] Ricklin D, Lambris JD (2007). Complement-targeted therapeutics. Nat Biotechnol, 25:1265-1275.

[362] Ehrnthaller C, Ignatius A, Gebhard F, Huber-Lang M (2011). New insights of an old defense system: structure, function, and clinical relevance of the complement system. Mol Med, 17:317-329.

[363] Zeerleder S (2011). C1-inhibitor: more than a serine protease inhibitor. Semin Thromb Hemost, 37:362374.

[364] De Simoni MG, Storini C, Barba M, Catapano L, Arabia AM, Rossi E, et al. (2003). Neuroprotection by complement $(\mathrm{C} 1)$ inhibitor in mouse transient brain ischemia. J Cereb Blood Flow Metab, 23:232-239.

[365] Chen X, Arumugam TV, Cheng YL, Lee JH, Chigurupati S, Mattson MP, et al. (2018). Combination Therapy with Low-Dose IVIG and a C1esterase Inhibitor Ameliorates Brain Damage and Functional Deficits in Experimental Ischemic Stroke. 20:63-72.

[366] Heydenreich N, Nolte MW, Gob E, Langhauser F, Hofmeister M, Kraft P, et al. (2012). C1-inhibitor protects from brain ischemia-reperfusion injury by combined antiinflammatory and antithrombotic mechanisms. Stroke, 43:2457-2467.

[367] Gesuete R, Storini C, Fantin A, Stravalaci M, Zanier ER, Orsini F, et al. (2009). Recombinant C1 inhibitor in brain ischemic injury. Ann Neurol, 66:332-342.

[368] Akita N, Nakase H, Kanemoto Y, Kaido T, Nishioka T, Sakaki T (2001). [The effect of C 1 esterase inhibitor on ischemia: reperfusion injury in the rat brain]. No To Shinkei, 53:641-644.

[369] Storini C, Rossi E, Marrella V, Distaso M, Veerhuis R, Vergani C, et al. (2005). C1-inhibitor protects against brain ischemia-reperfusion injury via inhibition of cell recruitment and inflammation. Neurobiol Dis, 19:1017.

[370] Ricklin D, Lambris JD (2016). Therapeutic control of complement activation at the level of the central component C3. Immunobiology, 221:740-746.

[371] Vogel CW, Finnegan PW, Fritzinger DC (2014). Humanized cobra venom factor: structure, activity, and therapeutic efficacy in preclinical disease models.
Mol Immunol, 61:191-203.

[372] Vogel CW, Fritzinger DC (2010). Cobra venom factor: Structure, function, and humanization for therapeutic complement depletion. Toxicon, 56:1198-1222.

[373] Hart ML, Walsh MC, Stahl GL (2004). Initiation of complement activation following oxidative stress. In vitro and in vivo observations. Mol Immunol, 41:165171.

[374] Hill JH, Ward PA (1971). The phlogistic role of C3 leukotactic fragments in myocardial infarcts of rats. $\mathrm{J}$ Exp Med, 133:885-900

[375] Morgan BP, Harris CL (2003). Complement therapeutics; history and current progress. Mol Immunol, 40:159-170.

[376] Vasthare US, Barone FC, Sarau HM, Rosenwasser RH, DiMartino M, Young WF, et al. (1998). Complement depletion improves neurological function in cerebral ischemia. Brain Res Bull, 45:413-419.

[377] Lassiter HA, Feldhoff RC, Dabhia N, Parker JC, Jr., Feldhoff PW (2001). Complement inhibition does not reduce post-hypoxic-ischemic cerebral injury in 21day-old rats. Neurosci Lett, 302:37-40.

[378] Weisman HF, Bartow T, Leppo MK, Marsh HC, Jr., Carson GR, Concino MF, et al. (1990). Soluble human complement receptor type 1: in vivo inhibitor of complement suppressing post-ischemic myocardial inflammation and necrosis. Science, 249:146-151.

[379] Kirschfink M (2001). Targeting complement in therapy. Immunol Rev, 180:177-189.

[380] Iida K, Nussenzweig V (1983). Functional properties of membrane-associated complement receptor CR1. J Immunol, 130:1876-1880.

[381] Fearon DT (1979). Regulation of the amplification C3 convertase of human complement by an inhibitory protein isolated from human erythrocyte membrane. Proc Natl Acad Sci U S A, 76:5867-5871.

[382] Hill J, Lindsay TF, Ortiz F, Yeh CG, Hechtman HB, Moore FD, Jr. (1992). Soluble complement receptor type 1 ameliorates the local and remote organ injury after intestinal ischemia-reperfusion in the rat. $\mathrm{J}$ Immunol, 149:1723-1728.

[383] Jaeschke H, Farhood A, Bautista AP, Spolarics Z, Spitzer JJ (1993). Complement activates Kupffer cells and neutrophils during reperfusion after hepatic ischemia. Am J Physiol, 264:G801-809.

[384] Chavez-Cartaya RE, DeSola GP, Wright L, Jamieson NV, White DJ (1995). Regulation of the complement cascade by soluble complement receptor type 1 . Protective effect in experimental liver ischemia and reperfusion. Transplantation, 59:1047-1052.

[385] Lehmann TG, Koeppel TA, Kirschfink M, Gebhard MM, Herfarth C, Otto G, et al. (1998). Complement inhibition by soluble complement receptor type 1 improves microcirculation after rat liver transplantation. Transplantation, 66:717-722.

[386] Shandelya SM, Kuppusamy P, Herskowitz A, Weisfeldt ML, Zweier JL (1993). Soluble complement receptor type 1 inhibits the complement pathway and prevents contractile failure in the postischemic heart. Evidence that complement activation is required for 
neutrophil-mediated reperfusion injury. Circulation, 88:2812-2826.

[387] Yang S, Wang X, Zhang X, Lu Y, Wang Z (2013). Neuroprotective effects of the SCR1-3 functional domain of CR1 on acute cerebral ischemia and reperfusion injury in rats. Neurol Res, 35:976-983.

[388] Li S, Xian J, He L, Luo X, Tan B, Yang Y, et al. (2011). The protective effect of $\mathrm{SCR}(15-18)$ on cerebral ischemia-reperfusion injury. Neurol Res, 33:866-874.

[389] Mocco J, Mack WJ, Ducruet AF, King RG, Sughrue ME, Coon AL, et al. (2006). Preclinical evaluation of the neuroprotective effect of soluble complement receptor type 1 in a nonhuman primate model of reperfused stroke. J Neurosurg, 105:595-601.

[390] Ducruet AF, Mocco J, Mack WJ, Coon AL, Marsh HC, Pinsky DJ, et al. (2007). Pre-clinical evaluation of an sLe x-glycosylated complement inhibitory protein in a non-human primate model of reperfused stroke. J Med Primatol, 36:375-380

[391] Couser WG, Johnson RJ, Young BA, Yeh CG, Toth CA, Rudolph AR (1995). The effects of soluble recombinant complement receptor 1 on complementmediated experimental glomerulonephritis. J Am Soc Nephrol, 5:1888-1894.

[392] Heller A, Kunz M, Samakas A, Haase M, Kirschfink M, Koch T (2000). The complement regulators C1 inhibitor and soluble complement receptor 1 attenuate acute lung injury in rabbits. Shock, 13:285-290.

[393] Rabinovici R, Yeh CG, Hillegass LM, Griswold DE, DiMartino MJ, Vernick J, et al. (1992). Role of complement in endotoxin/platelet-activating factorinduced lung injury. J Immunol, 149:1744-1750.

[394] Piddlesden SJ, Storch MK, Hibbs M, Freeman AM, Lassmann H, Morgan BP (1994). Soluble recombinant complement receptor 1 inhibits inflammation and demyelination in antibody-mediated demyelinating experimental allergic encephalomyelitis. J Immunol, 152:5477-5484.

[395] Naka Y, Marsh HC, Scesney SM, Oz MC, Pinsky DJ (1997). Complement activation as a cause for primary graft failure in an isogeneic rat model of hypothermic lung preservation and transplantation. Transplantation, 64:1248-1255.

[396] Goodfellow RM, Williams AS, Levin JL, Williams BD, Morgan BP (1997). Local therapy with soluble complement receptor 1 (sCR1) suppresses inflammation in rat mono-articular arthritis. Clin Exp Immunol, 110:45-52.

[397] Brandt LJ (2017). Fecal Microbiota Therapy With a Focus on Clostridium difficile Infection. Psychosom Med, 79:868-873.

[398] Zimmerman JL, Dellinger RP, Straube RC, Levin JL (2000). Phase I trial of the recombinant soluble complement receptor 1 in acute lung injury and acute respiratory distress syndrome. Crit Care Med, 28:3149-3154.

[399] McCormack PL (2013). Immune globulin (human) $10 \%$ liquid: a review of its use in primary immunodeficiency disorders. BioDrugs, 27:393-400.

[400] Chen X AT, Cheng YL, Lee JH, Chigurupati S,
Mattson MP, Basta M. (2018). Combination Therapy with Low-Dose IVIG and a C1-esterase Inhibitor Ameliorates Brain Damage and Functional Deficits in Experimental Ischemic Stroke. . Neuromolecular Med, 20:63-72.

[401] Widiapradja A, Santro T, Basta M, Sobey CG, Manzanero S, Arumugam TV (2014). Intravenous immunoglobulin (IVIg) provides protection against endothelial cell dysfunction and death in ischemic stroke. Exp Transl Stroke Med, 6:7.

[402] Fann DY, Lee SY, Manzanero S, Tang SC, Gelderblom M, Chunduri P, et al. (2013). Intravenous immunoglobulin suppresses NLRP1 and NLRP3 inflammasome-mediated neuronal death in ischemic stroke. Cell Death Dis, 4:e790.

[403] Lok KZ, Basta M, Manzanero S, Arumugam TV (2015). Intravenous immunoglobulin (IVIg) dampens neuronal toll-like receptor-mediated responses in ischemia. J Neuroinflammation, 12:73.

[404] Widiapradja A, Vegh V, Lok KZ, Manzanero S, Thundyil J, Gelderblom M, et al. (2012). Intravenous immunoglobulin protects neurons against amyloid beta-peptide toxicity and ischemic stroke by attenuating multiple cell death pathways. J Neurochem, 122:321-332.

[405] Proctor LM, Arumugam TV, Shiels I, Reid RC, Fairlie DP, Taylor SM (2004). Comparative antiinflammatory activities of antagonists to $\mathrm{C} 3 \mathrm{a}$ and $\mathrm{C} 5 \mathrm{a}$ receptors in a rat model of intestinal ischaemia/reperfusion injury. $\mathrm{Br} \mathrm{J}$ Pharmacol, 142:756-764.

[406] Wu MC, Brennan FH, Lynch JP, Mantovani S, Phipps S, Wetsel RA, et al. (2013). The receptor for complement component $\mathrm{C} 3 \mathrm{a}$ mediates protection from intestinal ischemia-reperfusion injuries by inhibiting neutrophil mobilization. Proc Natl Acad Sci U S A, 110:9439-9444.

[407] Busche MN, Stahl GL (2010). Role of the complement components $\mathrm{C} 5$ and $\mathrm{C} 3 \mathrm{a}$ in a mouse model of myocardial ischemia and reperfusion injury. Ger Med Sci, 8.

[408] Lillegard KE, Loeks-Johnson AC, Opacich JW, Peterson JM, Bauer AJ, Elmquist BJ, et al. (2014). Differential effects of complement activation products c3a and c5a on cardiovascular function in hypertensive pregnant rats. J Pharmacol Exp Ther, 351:344-351.

[409] Cheng Q, Patel K, Lei B, Rucker L, Allen DP, Zhu P, et al. (2018). Donor pretreatment with nebulized complement $\mathrm{C} 3$ a receptor antagonist mitigates braindeath induced immunological injury post-lung transplant. Am J Transplant.

[410] Li L, Chen L, Zang J, Tang X, Liu Y, Zhang J, et al. (2015). C3a and C5a receptor antagonists ameliorate endothelial-myofibroblast transition via the Wnt/betacatenin signaling pathway in diabetic kidney disease. Metabolism, 64:597-610.

[411] Li L, Yin Q, Tang X, Bai L, Zhang J, Gou S, et al. (2014). C3a receptor antagonist ameliorates inflammatory and fibrotic signals in type 2 diabetic nephropathy by suppressing the activation of TGF- 
beta/smad3 and IKBalpha pathway. PLoS One, 9:e113639.

[412] Hutamekalin P, Takeda K, Tani M, Tsuga Y, Ogawa N, Mizutani N, et al. (2010). Effect of the C3a-receptor antagonist SB 290157 on anti-OVA polyclonal antibody-induced arthritis. J Pharmacol Sci, 112:56-63. [413] Rynkowski MA, Kim GH, Garrett MC, Zacharia BE, Otten ML, Sosunov SA, et al. (2009). C3a receptor antagonist attenuates brain injury after intracerebral hemorrhage. J Cereb Blood Flow Metab, 29:98-107.

[414] Ducruet AF, Zacharia BE, Sosunov SA, Gigante PR, Yeh ML, Gorski JW, et al. (2012). Complement inhibition promotes endogenous neurogenesis and sustained anti-inflammatory neuroprotection following reperfused stroke. PLoS One, 7:e38664.

[415] Jean WC, Spellman SR, Nussbaum ES, Low WC (1998). Reperfusion injury after focal cerebral ischemia: the role of inflammation and the therapeutic horizon. Neurosurgery, 43:1382-1396; discussion 1396-1387.

[416] Zhang K, Li GQ, He QH, Li Y, Tang M, Zheng QY, et al. (2017). C5a/C5aR pathway accelerates renal ischemia-reperfusion injury by downregulating PGRN expression. Int Immunopharmacol, 53:17-23.

[417] Wada K, Montalto MC, Stahl GL (2001). Inhibition of complement $\mathrm{C} 5$ reduces local and remote organ injury after intestinal ischemia/reperfusion in the rat. Gastroenterology, 120:126-133.

[418] Riedemann NC, Guo RF, Ward PA (2003). A key role of $\mathrm{C} 5 \mathrm{a} / \mathrm{C} 5 \mathrm{aR}$ activation for the development of sepsis. J Leukoc Biol, 74:966-970.

[419] Jacob A, Hack B, Bai T, Brorson JR, Quigg RJ, Alexander JJ (2010). Inhibition of C5a receptor alleviates experimental CNS lupus. J Neuroimmunol, 221:46-52.

[420] Brennan FH, Gordon R, Lao HW, Biggins PJ, Taylor SM, Franklin RJ, et al. (2015). The Complement Receptor C5aR Controls Acute Inflammation and Astrogliosis following Spinal Cord Injury. 35:65176531.

[421] Zhang C, Li Y, Wang C, Wu Y, Du J (2014). Antagonist of $\mathrm{C} 5 \mathrm{aR}$ prevents cardiac remodeling in angiotensin II-induced hypertension. Am J Hypertens, 27:857-864.

[422] Li G, Fan RM, Chen JL, Wang CM, Zeng YC, Han C, et al. (2014). Neuroprotective effects of argatroban and $\mathrm{C} 5 \mathrm{a}$ receptor antagonist (PMX53) following intracerebral haemorrhage. Clin Exp Immunol, 175:285-295.

[423] Thiruma V. Arumugam S-CT, Justin D. Lathia, Aiwu Cheng, Mohamed R. Mughal, Srinivasulu Chigurupati, Tim Magnus, Sic L. Chan, Dong-Gyu Jo, Xin Ouyang, David P. Fairlie, Daniel N. Granger, Alexander Vortmeyer, Milan Basta and Mark P. Mattson (2007).
Intravenous immunoglobulin (IVIG) protects the brain against experimental stroke by preventing complement-mediated neuronal cell death. Proc Natl Acad Sci U S A, 104:14104-14109.

[424] Vakeva AP, Agah A, Rollins SA, Matis LA, Li L, Stahl GL (1998). Myocardial infarction and apoptosis after myocardial ischemia and reperfusion: role of the terminal complement components and inhibition by anti-C5 therapy. Circulation, 97:2259-2267.

[425] Kim GH, Mocco J, Hahn DK, Kellner CP, Komotar RJ, Ducruet AF, et al. (2008). Protective effect of C5a receptor inhibition after murine reperfused stroke. Neurosurgery, 63:122-125; discussion 125-126.

[426] Ricklin D, Lambris JD (2016). New milestones ahead in complement-targeted therapy. Semin Immunol, 28:208-222.

[427] Holers VM, Rohrer B, Tomlinson S (2013). CR2mediated targeting of complement inhibitors: benchto-bedside using a novel strategy for site-specific complement modulation. Adv Exp Med Biol, 735:137154.

[428] Tomasi S, Sarmientos P, Giorda G, Gurewich V, Vercelli A (2011). Mutant prourokinase with adjunctive $\mathrm{C} 1$-inhibitor is an effective and safer alternative to tPA in rat stroke. PLoS One, 6:e21999.

[429] Akita N, Nakase H, Kaido T, Kanemoto Y, Sakaki T (2003). Protective effect of $\mathrm{C} 1$ esterase inhibitor on reperfusion injury in the rat middle cerebral artery occlusion model. Neurosurgery, 52:395-400; discussion 400-391.

[430] Xi G, Hua Y, Keep RF, Younger JG, Hoff JT (2001). Systemic complement depletion diminishes perihematomal brain edema in rats. Stroke, 32:162167.

[431] Lew SM, Gross CE, Bednar MM, Russell SJ, Fuller SP, Ellenberger CL, et al. (1999). Complement depletion does not reduce brain injury in a rabbit model of thromboembolic stroke. Brain Res Bull, 48:325-331.

[432] Lok KZ, Manzanero S, Arumugam TV (2016). Neuronal low-density lipoprotein receptor-related protein 1 (LRP1) enhances the anti-apoptotic effect of intravenous immunoglobulin (IVIg) in ischemic stroke. Brain Res, 1644:192-202.

[433] Tunik S, Aluclu MU, Acar A, Akkoc H, Guzel A, Alabalik U, et al. (2016). The effects of intravenous immunoglobulin on cerebral ischemia in rats: An experimental study. Toxicol Ind Health, 32:229-234.

[434] Walberer M, Nedelmann M, Ritschel N, Mueller C, Tschernatsch M, Stolz E, et al. (2010). Intravenous immunoglobulin reduces infarct volume but not edema formation in acute stroke. Neuroimmunomodulation, 17:97-102. 